\title{
EFEITO DE DOIS MÉTODOS DE COCÇÃO - ÁGUA E VAPOR - NOS PARÂMETROS DE QUALIDADE DO MÚSCULO SEMITENDINOSUS
}

\author{
MARIELEN DE LIMA SILVA
}

Dissertação apresentada à Escola Superior de Agricultura "Luiz de Queiroz", Universidade de São Paulo, para obtenção do título de Mestre em Ciências, Área de Concentração: Ciência e Tecnologia de Alimentos.

\author{
PIR A C I C A B A \\ Estado de São Paulo - Brasil \\ Novembro - 2004
}




\title{
EFEITO DE DOIS MÉTODOS DE COCÇÃO - ÁGUA E VAPOR - NOS PARÂMETROS DE QUALIDADE DO MÚSCULO SEMITENDINOSUS
}

\author{
MARIELEN DE LIMA SILVA
}

Médico Veterinário

Orientador: Profa ${ }^{\text {. }} \mathrm{Dr}^{\mathrm{a}}$. CARMEM JOSEFINA CONTRERAS CASTILLO

Dissertação apresentada à Escola Superior de Agricultura "Luiz de Queiroz", Universidade de São Paulo, para obtenção do título de Mestre em Ciências, Área de Concentração: Ciência e Tecnologia de Alimentos.

\author{
PIR A C ICABA \\ Estado de São Paulo - Brasil \\ Dezembro - 2004
}




\section{Dados Internacionais de Catalogação na Publicação (CIP) DIVISÃO DE BIBLIOTECA E DOCUMENTAÇÃO - ESALQ/USP}

Silva, Marielen de Lima

Efeito de dois métodos de cocção - água e vapor - nos parâmetros de qualidade do músculo Semitendinosus / Marielen de Lima Silva. - - Piracicaba, 2004.

$102 \mathrm{p}$.

Dissertação (Mestrado) - - Escola Superior de Agricultura Luiz de Queiroz, 2004.

Bibliografia.

1. Carnes e derivados - Maciez 2. Cozimento 3. Microbiologia de alimentos 4 . Qualidade dos alimentos 5. Tratamento térmico I. Título

CDD 664.9

"Permitida a cópia total ou parcial deste documento, desde que citada a fonte - O autor" 
À meus pais, Alencar e Regina, pelo amor e dedicação de toda uma vida. 


\section{AGRADECIMENTOS}

Em primeiro lugar, gostaria de agradecer a $\operatorname{Prof}^{\mathrm{a}} \mathrm{Dr}^{\mathrm{a}}$ Carmen $\mathrm{J}$. Contreras Castillo, pela amizade e pela compreensão que marcaram a orientação desse trabalho, principalmente nos seus momentos mais difíceis.

Ao Instituto de Tecnologia de Alimentos (ITAL) - Centro de Tecnologia de Carnes (CTC) que possibilitou a realização do experimento nas suas instalações. Agradeço aos estagiários Nelisa Lamas e Bruno pela dedicação durante a realização do experimento.

À CAPES pela concessão da bolsa para a realização do trabalho.

Aos membros da banca de qualificação - Expedito Tadeu Facco Silveira, Martha Fillet Spoto e Solange Canniatti Brazaca - pelas valiosíssimas observações que foram fundamentais para a conclusão dessa dissertação.

À Alfredo de Almeida Vitalli, pela generosidade em partilhar comigo não somente seus sábios ensinamentos científicos como os de vida.

Nesse período tive o privilégio de conhecer pessoas que se tornaram importantes não só pela solidariedade durante realização do trabalho, mas também pela amizade que marcaram de forma muito especial esse período. À Anna Cecília Venturini pelo apoio e observações pertinentes; à Aelson Aloir Santana Brum, pela dedicação nos momentos finais; à Tatiana Pacheco Nunes, Roberta Claro da Silva e Érika Furlan amigas fiéis.

Aos amigos do mestrado pelo companheirismo nos momentos difíceis, mas também pelos momentos divertidos que passamos juntos: Roberta Teresa Rizzo Benato, Juliana Galvão, Eloíse Ribeiro, Selma Pacheco, Fabiana Curti, Débora Olivieri e o prof. Dr. Jorge Horii. 
À Ari Crespim dos Anjos, que dividiu comigo seus conhecimentos e experiência de forma extremamente generosa.

Há pessoas que mesmo não fazendo parte do ambiente da pesquisa se tornam fundamentais para que possamos permanecer nele. Soraia Vanessa Matarazzo, Sérgio Fernandes e a todos os amigos de Piracicaba pela receptividade. À Laura Moutinho que sempre me apoiou em tudo. Álvaro Comin pelo apoio e força tão oportunos nos momentos finais.

Aos meus irmãos Denise, Sílvia, Márcia e Rodrigo que mesmo de longe me deram a força necessária para que eu pudesse seguir adiante. 


\section{SUMÁRIO}

Página

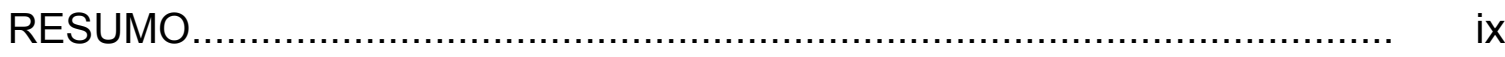

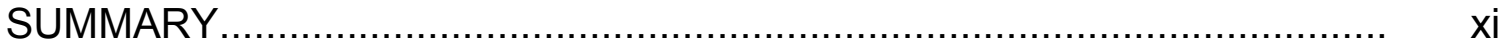

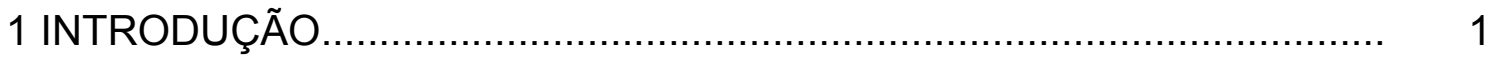

2 REVISÃO DE LITERATURA..................................................... 4

2.1 Músculo Semitendinosus................................................... 4

2.2 Estrutura e composição da carne.............................................. 5

2.3 Tratamento térmico aplicado à carne......................................... 8

2.4 Alterações na carne causadas pelo calor..................................... 10

2.5 Microbiologia da carne........................................................ 11

2.6 Controle de microrganismos patogênicos através do calor................... 14

2.7 Índices de qualidade da carne ............................................. 17

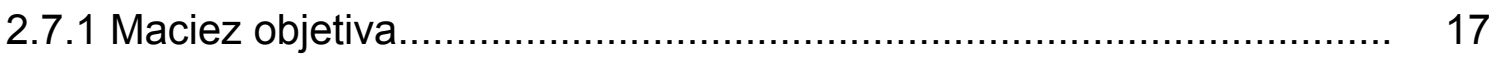

2.7.1.1 Relação entre maciez objetiva e percepção sensorial da textura..... 20

2.7.1.2 Análise descritiva quantitativa (ADQ) .................................... 21

2.7.1.3 Capacidade de retenção de água (CRA)................................. 24

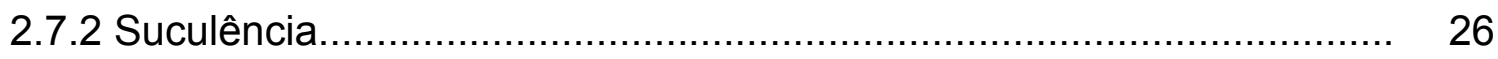

2.7.3 Rendimento e perdas por cocção da carne..................................... 27

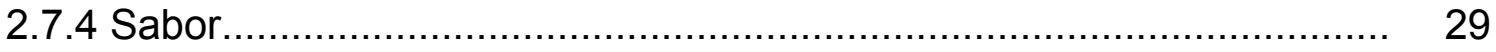

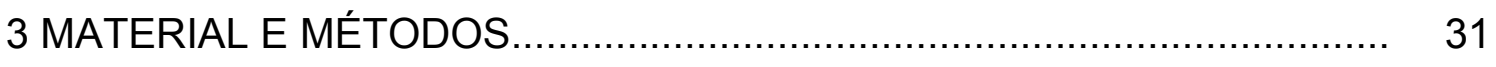

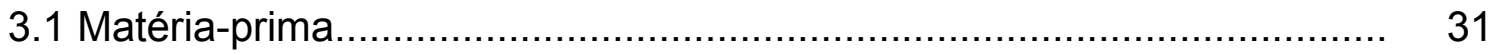

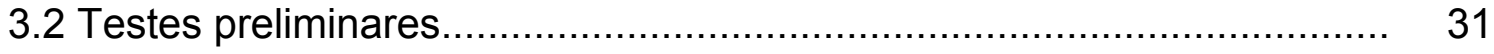




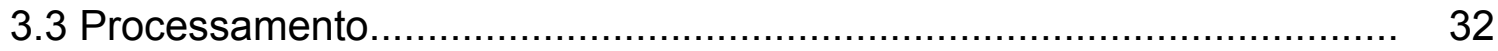

3.4 Análises físico-químicas............................................................ 33

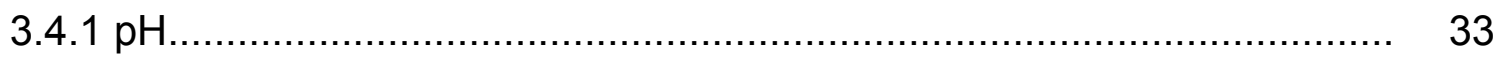

3.5 Avaliação do processo de aquecimento............................................. 33

3.6 Análises microbiológicas.............................................................. 34

3.7 Análises físicas.......................................................................... 35

3.7.1 Perdas durante a cocção........................................................ 35

3.7.2 Capacidade de retenção de água.................................................. 35

3.7.3 Medida da maciez objetiva do teste de avaliação de força de

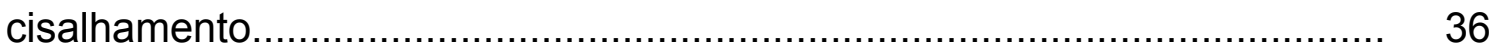

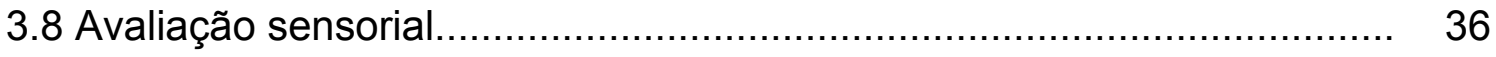

3.9 Delineamento experimental....................................................... 39

3.10 Análises estatísticas............................................................... 39

4 RESULTADOS E DISCUSSÃO ..................................................... 40

4.1 Análises físico-químicas............................................................ 41

4.2 Composição centesimal........................................................... 41

4.3 Avaliação do processo de cozimento............................................... 43

4.4 Avaliação microbiológica....................................................................... 45

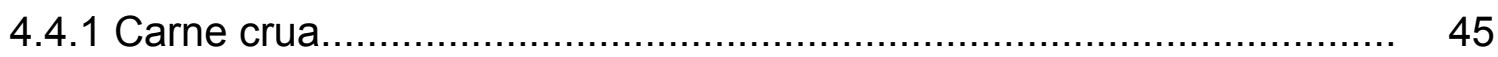

4.4.2 Avaliação microbiana da carne cozida.......................................... 47

4.5 Capacidade de retenção de água.................................................. 49

4.6 Avaliação das perdas por cocção....................................................... 52

4.7 Maciez objetiva..................................................................... 55

4.8 Análise sensorial.......................................................................... 58

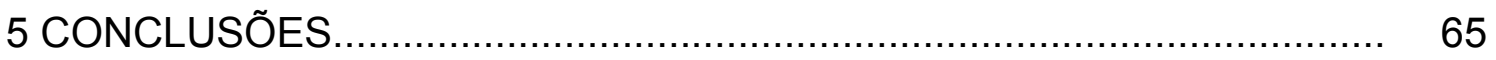

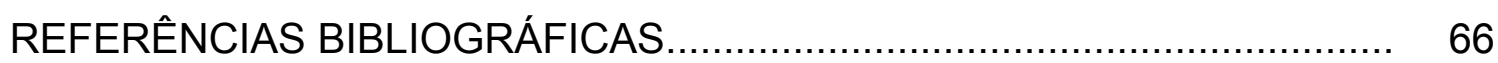

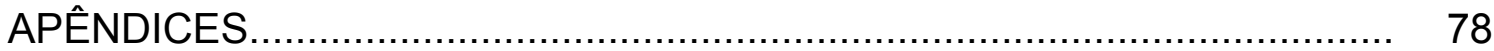




\title{
EFEITO DE DOIS MÉTODOS DE COCÇÃO - ÁGUA E VAPOR - NOS PARÂMETROS DE QUALIDADE DO MÚSCULO SEMITENDINOSUS
}

\author{
Autor: MARIELEN DE LIMA SILVA

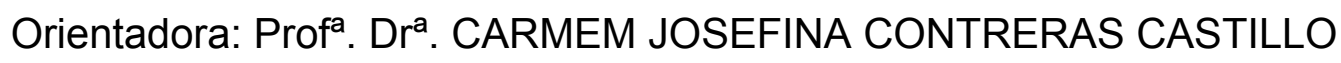

\section{RESUMO}

\begin{abstract}
A produção industrial de carnes requer o conhecimento de seu comportamento durante o aquecimento. Visando o controle do processo, são necessários dados relativos às características microbiológicas da carne crua, a composição centesimal da carne cozida, o tratamento térmico aplicado e suas conseqüências na flora microbiana do produto. Avaliar a efetividade de diferentes tratamentos térmicos, os índices de qualidade e o rendimento dos cortes de carne são os objetivos deste trabalho. Foram utilizadas amostras de músculos Semitendinosus de carne bovina cozidas em dois meios de aquecimento, água e vapor, em duas temperaturas $\left(70^{\circ} \mathrm{C}\right.$ e $\left.80^{\circ} \mathrm{C}\right)$. A efetividade do tratamento térmico aplicado às amostras foi avaliada através da elaboração da curva de penetração de calor em cada uma das amostras, calculando-se os valores $\mathrm{P}$ de pasteurização $\mathrm{e}$ as reduções decimais alcançada. Foram avaliadas as influências da temperatura e do tipo de aquecimento, isoladamente, na capacidade de retenção de água (CRA), assim como, a interação entre as variáveis. Os fatores i) perdas por cocção e ii) maciez objetiva foram analisados conjuntamente relacionando-as com as temperaturas e os tipos de aquecimento experimentados. Observou-se através
\end{abstract}


de avaliação sensorial em que medida os fatores como a presença de tecido conjuntivo, suculência e sabor influenciaram a maciez do corte de Semitendinosus. Os resultados mostram que a temperatura de $70^{\circ} \mathrm{C}$ não foi suficiente para a pasteurização neste experimento, tendo como microrganismo alvo o Clostridium botulinum tipo E. A maciez objetiva não foi influenciada por nenhum dos tratamentos. $\mathrm{Na}$ análise sensorial a variável maciez foi significativamente influenciada pela presença de colágeno de forma negativa e pela suculência de forma positiva. 


\title{
EFFECT OF TWO METHODS OF HEATING - WATERBATH AND STEAM - IN THE PARAMETERS OF QUALITY OF SEMITENDINOSUS MUSCLE
}

\author{
Author: MARIELEN DE LIMA SILVA

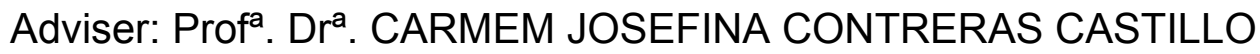

\section{SUMMARY}

The industrial manufacturing of meat requires the knowledge of its behavior in the course of the cooking process. To control the process it's absolutely necessary to have data relative to the microbiological characteristics of the raw meat, the centesimal composition of the cooked meat, the thermal treatment applied and its consequences in the flora of the product. To evaluate the effectiveness of different thermal treatments, the levels of quality and the performance of meat cuts are the purposes of this work. Samples of Semitendinosus muscles of cooked bovine meat were submitted to two ways of heating, water and steam, under two temperatures $\left(70^{\circ} \mathrm{C}\right.$ and $\left.80^{\circ} \mathrm{C}\right)$. The effectiveness of the applied thermal treatment to the samples was evaluated through the elaboration of the curve of penetration of heat in each one of the samples, calculating its $P$ values of pasteurization and the decimal reductions reached. The influences of the temperature and the way of cooking have been evaluated, separately, in the water holding capacity (WHC), as well as the interaction between the variables. The factors i) cooking losses ii) objective tenderness were analyzed jointly relating them with the temperatures and the distinct ways of cooking. Sensorial evaluation was used to measure the 
influences of factors like conjunctive presence, juiciness and flavor over the tenderness of the cut of Semitendinosus. The experiment showed that the temperature of $70^{\circ} \mathrm{C}$ was not enough to pasteurize the $E$ type Clostridium botulinum microorganism. The objective tenderness was not influenced by any of the procedures. The sensorial analysis showed that tenderness was significantly influenced negatively by the presence of connective tissue and positively by the juiciness. 


\section{INTRODUÇÃO}

Os produtos prontos e semiprontos para consumo constituem atualmente uma excelente alternativa para o mercado. Para o produtor de alimentos, é uma forma de agregar valor à matéria prima. Para o consumidor, a aquisição dos mesmos se faz oportuna, diante da necessidade crescente de minimizar o tempo de preparo dos alimentos.

Segundo Belchior (2004), uma peculiaridade relativa ao consumidor brasileiro é que se trata de "um consumidor que quer autenticidade, isto é, além de estar aberto à culinária estrangeira, permanece firmemente apegado às tradições e aos produtos locais. Ou, seja, querem adquirir e consumir produtos de sabor caseiro, com características muito próximas aos pratos que elaboram em casa, sem o chamado sabor industrial".

As vantagens associadas aos produtos cárneos elaborados industrialmente e embalados a vácuo de forma a serem abertos somente no ato da finalização de sua preparação são muitas. A maior delas diz respeito à segurança microbiológica decorrente do menor contato eliminando a possibilidade de contaminação por parte do manipulador na indústria, o que aumenta a vida de prateleira do produto. Ocorre ainda um incremento nos atributos sensoriais tais como suculência, sabor e aroma do produto.

Segundo Sarantopólus (2001), o acondicionamento de produtos cárneos pode ser feito em sacos pré-formados, utilizando-se máquinas de vácuo. A autora cita ainda que as principais características deste tipo de material são a barreira ao oxigênio e a baixa taxa de permeabilidade ao vapor d'água evitando a desidratação superficial. Também evita a perda do aroma, 
tendo boa resistência mecânica, reduzindo danos de abrasão e perfuração nas operações de manuseio e distribuição. Além disso, são necessárias boas propriedades de termossoldabilidade, mesmo em áreas eventualmente contaminadas pelo produto, para minimizar problemas de vazamento e conseqüente perda de vácuo.

A carne cozida congelada, utilizada para elaboração de pratos prontos, é considerada pela indústria alimentícia um dos principais produtos do mercado de carnes semi-prontas. Ressalta-se, porém, a existência de problemas relativos à sua maciez e suculência que dificultam sua elaboração industrial (Belchior, 2004).

Para a obtenção de um produto com alta aceitabilidade há a necessidade do estabelecimento de critérios de processamento que permitam maior padronização no produto final. Este tem que atender aos aspectos de inocuidade, eliminando-se e/ou controlando-se os microrganismos patogênicos que eventualmente estejam presentes na matéria prima, devendo ainda, possuir características sensoriais que satisfaçam o consumidor (Felício, 2004).

O músculo Semitendinosus é conhecido popularmente como "Lagarto". Este músculo pode resultar num produto com excelentes atributos de qualidade, particularmente aqueles relacionados com a maciez.

O comportamento da carne durante o cozimento industrial deve ser observado visando-se o controle de processo. Para tanto, são necessários dados relativos às características microbiológicas da carne crua, a composição centesimal da carne cozida, o tratamento térmico aplicado e suas conseqüências na flora microbiana do produto. Faz-se necessário também avaliar os rendimentos encontrados e a percepção das características sensoriais do produto.

Os objetivos deste trabalho foram: avaliar a efetividade do tratamento térmico aplicado às amostras sob o ponto de vista microbiológico tendo como microrganismo alvo o Clostridium botulinum tipo E, avaliar os índices de qualidade, rendimento, maciez objetiva e aferir em que medida a maciez 
subjetiva exerceu influência nos atributos sabor, presença de colágeno, e suculência das amostras submetidas a cozimento em temperaturas de $70^{\circ} \mathrm{C}$ e $80^{\circ} \mathrm{C}$ nos meios utilizando água e vapor. 


\section{REVISÃO DE LITERATURA}

\subsection{Músculo Semitendinosus}

Localizado no quarto traseiro dos bovinos, o músculo Semitendinosus corresponde ao que se denomina popularmente de "Lagarto". É o corte constituído da massa muscular no seu limite antero-lateral pelo glúteo-bíceps (coxão duro) e o limite inferior são: o Sartório, Reto interno, Pectíneo, Adutor, Semimembranoso, Gêmeos, Obturador externo e interno e Quadrado femural (todos estes músculos constituem o coxão mole). A preparação do corte é obtida pela liberação das massas musculares aderidas ao coxão duro, coxão mole e músculo mole. (EMBRAPA, 2004).

Segundo Franco (2002), a composição centesimal em $100 \mathrm{~g}$ do corte de "Lagarto" cozido é: gordura $-13 \%$, proteínas- $27 \%$, cinza- $0,4 \%$ e carboidratos totais $0 \%$.

O United States Departament of Agriculture (USDA) (2004) cita a composição centesimal da carne cozida em geral, isto é, sem especificar a que corte pertence, e acordo com o método de cozimento utilizado. Os valores estão na Tabela 1. 
Tabela 1. Composição centesimal da carne cozida refogada, grelhada e assada

\begin{tabular}{lccccc}
\hline & Umidade & Lipídeos & Proteína & Carboidratos & Cinza \\
\hline Refogada & 57,4 & 7,72 & 34,34 & 0 & 0,54 \\
Grelhada & 65,51 & 4,7 & 29,72 & 0 & 0,07 \\
Assada & 64,29 & 5,83 & 25,01 & 0 & 4,87 \\
\hline
\end{tabular}

Fonte: USDA (2004)

\subsection{Estrutura e composição da carne}

O músculo e os demais tecidos que compõem a carne são constituídos pelo tecido muscular e os tecidos anexos. Os tecidos anexos são formados pelo tecido conjuntivo, tecido epitelial e nervoso (Pardi et al., 1995). Segundo Bouton \& Harris (1975), a carne pode ser considerada um conjunto de fibras paralelas possuidoras de uma estrutura fibrilar, envolvida por um tecido conjuntivo que é responsável pela organização estrutural do músculo.

A composição da carne utilizada para consumo humano é em sua grande maioria constituída pelo tecido muscular esquelético. A unidade estrutural do tecido muscular é uma célula altamente especializada que denomina-se fibra muscular. A fibra muscular é constituída por três grupos de proteínas musculares com características histológicas distintas: as proteínas miofibrilares, as sarcoplasmáticas, as estromáticas (Pardi et al., 1995).

As proteínas miofibrilares também chamadas citoesqueléticas são conjuntamente denominadas miofibrilas, exercem a função de contração muscular, além de serem as que ocorrem em maior abundância, porém estão presentes apenas em alguns tipos de músculo. São responsáveis pela organização do sarcômero, que é a unidade básica onde os eventos de contração e relaxamento muscular ocorrem. São formadas pelas seguintes proteínas: miosina, proteína $\mathrm{C}$, proteína $\mathrm{M}$ formadoras do filamento grosso; 
actina, tropomiosina, troponina, e $\beta$ - actinina formadora do filamento fino; $\alpha$ actinina e desmina formadoras da linha $Z$. A actina e a miosina são as que estão presentes em maior quantidade nos filamentos finos e grossos, respectivamente. Como resultado dessa disposição, denomina-se banda I aquela formada por filamentos finos não invadidos por filamentos grossos. A banda A é formada principalmente por filamentos grossos, e a banda $\mathrm{H}$ somente por filamentos grossos. No centro de cada banda I aparece uma linha transversal escura denominada linha Z (Judge et al., 1989a).

Quanto à solubilidade, as proteínas podem ser solúveis em água ou solúveis em solução salina (as proteínas sarcoplasmáticas), proteínas solúveis em solução salina concentrada (miofibrilares) e proteínas insolúveis do tecido conjuntivo e estruturais (Bailey \& Light, 1989)

As proteínas estromáticas são as responsáveis pela estruturação do músculo, sendo formadas por colágeno, elastina, reticulina e outras proteínas insolúveis. O colágeno sob a ação do calor é capaz de se gelatinizar sendo esta uma característica extremamente importante nos processos que envolvem o cozimento de produtos alimentícios (Bailey \& Light, 1989).

No grupo das proteínas sarcoplasmáticas existem a mioglobina, a hemoglobina e ainda as proteínas envolvidas no sistema enzimático celular que são o citocromo, as flavoproteínas além das proteínas mitocondriais (Pardi et al., 1995). Estas representam uma mistura complexa de 50 componentes, muitos dos quais são enzimas glicolíticas. São suscetíveis a desnaturação. 


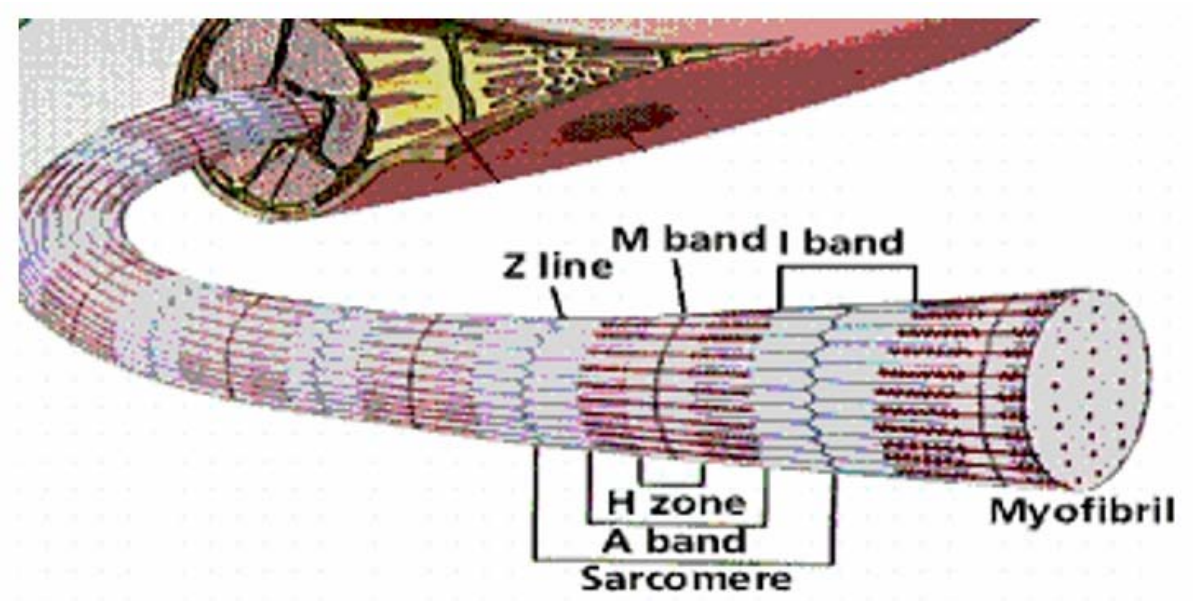

Figura 1 - Desenho esquemático ilustrando a organização do músculo esquelético

A camada de tecido conjuntivo que envolve cada fibra muscular é denominada endomísio. Pequenos feixes de fibras musculares agrupadas também são envolvidos por uma membrana conjuntiva sendo esta denominada perimísio. O grupo muscular como um todo é envolvido por uma camada denominada epimísio que se continuam com os tendões, responsáveis pela fixação da musculatura esquelética (Pardi, 1995). Portanto, na constituição do músculo estão intimamente associadas as fibras musculares e o tecido conjuntivo.

$\mathrm{O} \mathrm{pH}$ da carne crua, em condições de normalidade, isto é, não tendo o animal vivo passado por condições de estresse no pré-abate, encontra-se entre 5,4 e 5,9. A elevação do pH na carne tem como conseqüência indesejável a formação de uma carne escura, dura e seca denominada DFD. Esta característica afeta as características finais dos produtos cárneos em geral (Faustman \& Cassens, 1990). 


\subsection{Tratamento térmico aplicado à carne}

Grande parte da carne e produtos cárneos consumidos atualmente pelo homem, passa por tratamento térmico, por isso muitos são os estudos acerca dos efeitos da temperatura sobre a carne.

Com relação ao cozimento de produtos em geral, existem vários meios de se transferir calor para um produto. Os meios de transferência de calor podem ser divididos em: irradiação, convecção e condução. A irradiação ocorre por via eletromagnética onde um corpo quente emite a energia e esta é absorvida por um corpo frio. A convecção ocorre através da passagem do calor dos meios fluidos para um sólido. O processo de convecção pode acontecer de forma livre ou forçada. Nos casos de convecção forçada é necessário que movimentos sejam produzidos por ação exterior de forma a aumentar a velocidade do processo. Normalmente ocorre com a presença de ventiladores ou vapor. Já a condução obedece a uma distribuição homogênea de temperatura no meio pela difusão de zonas mais quentes onde a energia é alta para zonas mais frias onde a energia é baixa (Brennan et al., 1980).

Segundo Girard (1991), as transferências de calor na carne e nos produtos cárneos ocorrem primeiro com o aporte de energia até a superfície da carne, sendo que depois há a penetração na mesma. Quanto ao modo de transferência de calor, este vai variar de acordo com cada tipo de cozimento. No caso da convecção o fluido aquecedor poderá ser a água, o vapor d'água, o ar úmido ou as gorduras. Os métodos de cozimento utilizando a convecção podem se valer de diferentes meios de cozimento tais como o ar seco, o úmido e as frituras. Price \& Schweigert (1994a), citam que o aquecimento visando o cozimento a seco se caracteriza por utilizar tempos mais curtos em temperaturas altas.

A irradiação intervém na preparação de assados em sua primeira fase. A condução é o modo de transferência que ocorre nos produtos grelhados e na

primeira fase dos produtos assados. Em alguns casos particulares não há 
transferência de calor ocorrendo dissipação direta de energia pela massa do produto a aquecer. São os casos de cozimento por microondas ou por condução elétrica (Price e Schweigert 1994b).

Quanto à seleção do método de cozimento a ser utilizado, Price e Schweigert (1994b) afirmaram que este pode afetar as características como maciez, suculência e sabor, bem como as propriedades mecânicas da carne .

Segundo Powell (2000), o cozimento a seco utilizando o forno convencional resulta numa carne menos macia quando esta foi proveniente de cortes que possuíam quantidades elevadas de tecido conjuntivo, tal como o Semitendinosus, quando comparada à maciez encontrada em cortes com baixo teor do mesmo, tal como a carne proveniente de Longissimus dorsi.

A American Meat Science Association (AMSA,1995) seleciona os métodos de cozimento assado, refogado e grelhado para os estudos científicos, visto serem estes os mais comuns tanto na aplicação industrial quanto na aplicação caseira.

Para o cozimento de alimentos, a indústria atualmente dispõe de vários equipamentos que utilizam diferentes meios de cozimento . Os mais comuns são os fornos, estufas e recipientes abertos ou fechados tais como tachos ou autoclaves. Segundo AMSA (1995), a seleção do equipamento a ser utilizado depende de um trabalho junto às indústrias, uma vez que as informações não se encontram prontamente disponíveis. São consideradas fundamentais as seguintes informações para obtenção de dados sobre cozimento: sensibilidade e acuidade do controle de temperatura; ampla variação de temperatura; ampla freqüência de temperatura e variação que inclua os termos "quente" e "frio".

Powell (2000) avaliou a maciez e a composição do colágeno em bifes de Semitendinosus cozidos em fornos convencionais com tempos diferenciados em um único e em três estágios de cozimento e conclui quando se utilizou três estágios de cozimento obteve-se um produto mais macio e com maior suculência. 


\subsection{Alterações na carne causadas pelo calor}

O calor provoca alterações na aparência, sabor, textura e valor nutritivo da carne. As alterações mais drásticas, durante o cozimento, estão relacionadas ao encolhimento e o endurecimento do tecido com conseqüente liberação de suco e a mudança de cor causadas pelas alterações das proteínas do músculo (Hamm, 1980).

Segundo Hamm (1977), a desnaturação da miosina se inicia a $30^{\circ} \mathrm{C} \mathrm{e}$ se completa a $50^{\circ} \mathrm{C}$, com um decréscimo da solubilidade a $60^{\circ} \mathrm{C}(\mathrm{pH} \mathrm{5,4).} \mathrm{A}$ desnaturação do actina $\mathrm{G}$ ocorre na faixa entre $30^{\circ} \mathrm{C}-50^{\circ} \mathrm{C}$ e a da actina $\mathrm{F}$ entre $40^{\circ} \mathrm{C}-60^{\circ} \mathrm{C}$. Na faixa de $40^{\circ} \mathrm{C}$ ocorreu alterações da molécula de actomiosina, devido à liberação de íons $\mathrm{Ca}^{++}$e aumento da atividade da ATP ase.

Christensen et al. (2000), afirmaram que o maior decréscimo da solubilidade das proteínas miofibrilares, durante o cozimento da carne, ocorreu em temperaturas entre $40^{\circ} \mathrm{C}$ e $60^{\circ} \mathrm{C}$; acima de $60^{\circ} \mathrm{C}$ estas proteínas tornaram-se quase insolúveis. A actina apresentou maior termoestabilidade que a miosina. Com relação à desnaturação do colágeno os autores assinalaram que esta ocorre em temperaturas entre $65^{\circ} \mathrm{C}$ e $70^{\circ} \mathrm{C}$.

O processo de desnaturação do colágeno é amplamente discutido na literatura. Lakkonem et al. (1970) observaram que no caso da carne, as fibras de colágeno sofriam uma menor redução a $60^{\circ} \mathrm{C}$ do que quando submetidas a temperaturas mais elevadas. O autor observou o comportamento dos músculos Longissimus dorsi, Semitendinosus e Rectus femoris durante cozimento por até $24 \mathrm{~h}$ a temperaturas baixas (máximo $60^{\circ} \mathrm{C}$ ). Foram avaliados os índices maciez, capacidade de retenção de água, $\mathrm{pH}$, quantidade de componentes solúveis em água. Os autores concluíram que nas primeiras duas horas ocorreu um decréscimo bastante acentuado no índice de maciez, assim como um aumento nas perdas por cozimento. 
Hamm et al. (1983) afirmaram que as fibras de colágeno encolhiam de $1 / 3$ a $1 / 4$ do comprimento inicial em temperaturas próximas a $60^{\circ} \mathrm{C}$, sendo que em temperaturas maiores $o$ colágeno se transformava em gelatina hidrossolúvel. As alterações máximas da solubilidade e seu grau de encurtamento ocorreram na faixa de $55^{\circ} \mathrm{C}$ e $65^{\circ} \mathrm{C}$. O estudo realizado por Powell (2000), onde foram aquecidas amostras de Semitendinosus em um único e em três estágios de cozimento ressaltou que a desnaturação tempodependente da porção insolúvel do colágeno inicia-se a $55^{\circ} \mathrm{C}$. O trabalho ressaltou que com o aumento da temperatura de cozimento, foram observadas duas fases distintas na primeira fase utilizando-se temperaturas entre $40^{\circ} \mathrm{C}$ e $50^{\circ} \mathrm{C}$, a carne endurece $3-4$ vezes, dobrando na segunda fase, entre $65^{\circ} \mathrm{C}$ e $75^{\circ} \mathrm{C}$. A primeira fase foi associada com a desnaturação do sistema contrátil, em conseqüência da perda da solubilidade do complexo actomiosina e a segunda fase é associada com o encolhimento do colágeno.

As alterações estruturais além de causarem modificações texturais promoveram perda de líquido segundo Davey (1974) podendo variar entre $16 \%$ e $42 \%$.

\subsection{Microbiologia da carne}

No animal vivo, saudável, o tecido muscular é estéril devido aos seus mecanismos de defesa naturais. Os tecidos dos órgãos que contatam ou se comunicam com o meio externo, normalmente, apresenta uma microbiota intrínseca. Durante o processamento, os músculos, tornam-se contaminados com microrganismos através da pele e do aparelho gastrintestinal dos animais e essa contaminação se dá através dos microrganismos originalmente presentes nas fezes e no solo. Nas fases subseqüentes como esfola e manipulação da carne pode ocorrer uma nova contaminação através de equipamento e manipuladores (Judge et al., 1989b). 
A flora microbiana da carne bovina pode ser dividida em dois grupos: deteriorante e patogênica. A flora deteriorante é representada por Pseudomonas sp, Acinetobacter sp. e Moraxella sp. A flora patogênica compreende as bactérias da família Enterobacteriaceae, principalmente Salmonella sp. e Escherichia coli e alguns anaeróbios do gênero Clostridea (Judge et al., 1989).

A proliferação dos microrganismos na carne é influenciada por fatores extrínsecos e intrínsecos. Os fatores intrísecos compreendem a umidade, $\mathrm{pH}$, potencial de oxiredução e a disponibilidade de nutrientes na carne. Os fatores extrínsecos são representados pela tensão de gases, tensão de vapor, temperatura ideal de crescimento para cada microrganismo.

Com relação à temperatura, os microrganismos classificam-se em quatro grupos distintos: termófilos, mesófilos e psicrotróficos. Outros fatores extrínsecos são a tensão de gases e as tensões de vapor d'água existente no meio de multiplicação (Pelczar, 1997).

Segundo Hart (1995), o processo de resfriamento seleciona os microrganismos psicrófilos ou psicrotróficos. Aqui cabe destacar os gêneros Pseudomonas, Acinetobacter e Moraxella (Achromobacter). As cepas de Pseudomonas parecem crescer mais rapidamente e são as que se predominam em carnes refrigeradas mantidas por um longo tempo. Estas são móveis por possuírem flagelos. Com relação à flora patogênica que se desenvolve na carne bovina, os principais microrganismos envolvidos são: Escherichia coli, Salmonella sp, Clostridium perfringens e Clostridium botulinum.

O C. botulinum é um bacilo gram negativo anaeróbio, formador de endoesporos, encontrado no solo e em sedimentos em geral. A forma patogênica é a toxina que é uma neurotoxina altamente específica para a parte sinapxial do nervo. A toxina botulínica produzida pelo $C$. botulinum tipo $E$ é destruída pelos métodos de cozimento mais comuns, sendo que a adição de nitritos colabora com o impedimento do crescimento deste microrganismo. Os endósporos do botulismo $\mathrm{E}$ são menos resistentes que os de outras cepas, 
sendo geralmente destruído pela fervura. O tipo E não é proteolítico, de modo que a chance de causar deterioração em alimentos ricos em proteína é mínima. O patógeno também é capaz de produzir toxina em temperaturas de refrigeração além de requerer condições menos estritamente anaeróbias para seu crescimento (Tortora et al., 2000).

Até épocas recentes, o $C$. botulinum era um microrganismo que causava preocupação apenas para as indústrias de enlatados. Com o aumento da produção e comercialização de alimentos cozidos, embalados a vácuo e resfriados ele se tornou um risco potencial a ser considerado, principalmente quando se trata de produtos com pH superior a 4,5 onde não são acrescentados aditivos químicos tais como nitrato e nitrito, cuja utilização é muito comum em produtos cárneos (Junqueira, 1994).

O Clostridium botulinum tipo $E$ é um microrganismo que está associado aos riscos microbiológicos inerentes aos produtos cárneos cozidos, resfriados e embalados a vácuo, uma vez que é capaz de crescer e produzir toxina a uma temperatura de $3^{\circ} \mathrm{C}$ (Jay, 1996).

Tabela 2. Temperatura de crescimento das principais bactérias envolvidas com produtos cárneos

\begin{tabular}{lccc}
\hline \multicolumn{1}{c}{ Bactéria } & \multicolumn{3}{c}{ Temperatura ${ }^{\circ} \mathrm{C}$} \\
\hline Samonella sp. & 6,5 & Máxima & Ótima \\
Clostridium perfringens & 10 & 50 & 37 \\
Clostridium botulinum tipo A e B & 10 & 48 & 43 \\
Clostridium botulinum tipo E & 3,3 & 45 & 35 \\
Listeria sp & 5 & 45 & 30 \\
\hline
\end{tabular}

Fonte: Price (1994) 
Para a avaliação da qualidade microbiológica de carnes cruas, a Agência Nacional de Vigilância Sanitária (ANVISA) (RDC n 12 de 02 de janeiro de 2001) exige ausência de Salmonella sp em $25 \mathrm{~g}$ de amostra e contagem máxima de $5 \times 10^{3} \mathrm{UFC} / g$ Coliformes a $45^{\circ} \mathrm{C}$ ( coliformes fecais). Nos produtos cárneos cozidos, a mesma legislação estabelece como parâmetros as análises de Salmonella sp., cujo resultado deverá ser de ausência em $25 \mathrm{~g}$. Clostrídeos sulfito redutores com presença máxima permitida de $5 \times 10^{2}$ e Estafilococos coagulase positiva com índices máximos de $5 \times 10^{3} \mathrm{UFC} / \mathrm{g}$.

\subsection{Controle de microrganismos patogênicos através do calor}

O processo de cozimento tem como objetivo a obtenção de um produto com características organolépticas desejáveis. Além disso, é importante também que seja um produto seguro sob o ponto de vista microbiológico. Uma das formas de se obter um produto microbiologicamente seguro, é a utilização do calor. Segundo Leitão e Junqueira (1995), o controle microbiano pela utilização de calor em alimentos pode ser feito através de dois tipos básicos de tratamentos térmicos. O primeiro é a esterilização comercial para alimentos de baixa acidez $(\mathrm{pH}>4,6)$ e armazenados a temperatura ambiente, visando assegurar a completa destruição de bactérias patogênicas ou de microrganismos capazes de deteriorar produtos nas condições normais de armazenamento (geralmente temperaturas abaixo de $40^{\circ} \mathrm{C}$ ). Uma vez que muitos destes microrganismos deterioradores ou patogênicos são esporogênicos, o tratamento térmico deverá assegurar a destruição de esporos bacterianos, formas altamente resistentes à ação de agentes físicos e químicos, sendo, portanto, necessário o emprego de altas temperaturas (geralmente na faixa de $110^{\circ} \mathrm{C}$ a $120^{\circ} \mathrm{C}$ ) somente conseguidas através de autoclaves, sob pressão.

O segundo processo é o de pasteurização, sendo esta terminologia aplicada aos tratamentos térmicos menos intensos, sempre em temperaturas 
inferiores a $100^{\circ} \mathrm{C}$ e, portanto, sob pressão atmosférica normal. Estes processos são destinados aos alimentos que não oferecem condições para a proliferação das bactérias esporogênicas (por exemplo, alimentos ácidos ou muito ácidos, com pH inferior a 4,6), ou alimentos processados e submetidos posteriormente à refrigeração, congelamento, concentração, desidratação, portanto não oferecendo condições para a multiplicação das formas microbianas mais resistentes, que sobrevivem à pasteurização (Stumbo, 1965).

Os estudos de termobacteriologia avaliam a integração de tempo e temperatura de cozimento de produtos com o objetivo de inativar os microrganismos preocupantes. O microrganismo escolhido como alvo pode ser um patógeno ou um esporo termo-resistente. A escolha vai depender das características do produto a ser tratado termicamente, da estabilidade e da vida de prateleira que se objetiva. Uma vez identificado o organismo alvo, deve-se definir sua resistência ao cozimento do produto em questão. Os estudos sobre tempo de morte térmica (TDT) são conduzidos em laboratórios para determinar a resistência de microrganismos. Os fatores que comumente afetam a resistência dos microrganismos são a espécie e a cepa, características de crescimento, a temperatura média na qual ele é aquecido e sua capacidade de regeneração (Leitão e Junqueira, 1995).

Segundo Jay (1996), os estudos de TDT envolvem inoculações no produto, com um conhecimento das quantidades de organismos testes. A meta é encontrar o ponto de estagnação ou o tempo de destruição e sobrevivência do microrganismo em cada diferente temperatura e calcular as curvas de sobrevivência. Muitos estudos acerca de resistência térmica de organismos têm mostrado que a morte de um microrganismo é baseada no tempo e na temperatura em que ocorre a morte do microrganismo. Estes valores são expressos logaritmicamente, o que significa que o delineamento do número de sobrevivência versus o tempo de cozimento será dada na forma de uma linha reta. Uma redução de $90 \%$ na população ocorre em intervalo de tempo constante, independente da população inicial. Esta taxa de 90\% é denominada 
de ciclo logarítmico ou log redução ou valor $D$ (designando redução decimal). Um valor $\mathrm{D}$ é definido como o tempo em minutos em determinada temperatura constante necessário para destruir $90 \%$ ou um ciclo logarítmico dos organismos presentes. Os valores D são determinados pelas curvas de sobrevivência em diferentes temperaturas. Além do valor $D$, existe o valor $Z$ que corresponde ao intervalo da temperatura que ocasiona uma variação de 10 vezes no valor $D$, ou seja, 1 ciclo logarítmico.

Gonçalves (1992), observou que a obtenção de valores D e Z dos microrganismos "in vitro", apesar de ser possível, geralmente não se faz necessária uma vez que existem Tabelas com os valores $D$ e $Z$ de esporos e células vegetativas de bactérias, bolores e leveduras.

Segundo a AMSA (1995), o método clássico para se determinar a taxa de cozimento de um produto é através da medição da temperatura na mais baixa porção de cozimento do mesmo, onde o cozimento ocorre mais lentamente. Este local é também denominado "ponto frio" do produto. Nos produtos espessos ou densos esta porção normalmente corresponde ao centro geométrico do produto.

Os valores $\mathrm{D}$ e $\mathrm{Z}$ para o $\mathrm{C}$. botulinum tipo $\mathrm{E}$ em temperatura de teste de $82,2^{\circ} \mathrm{C}$, é $D=0,1-3 \mathrm{~min}$. e $Z=5,0-8,8^{\circ} \mathrm{C}$ (Stumbo, 1965).

A relação tempo e temperatura que permita um produto final de qualidade ideal para o consumidor é o objeto de muitas pesquisas na área em questão. Avaliando métodos de cozimento, Lawrence (2001), concluiu que os três métodos estudados por ele (forno elétrico, grelha industrial, forno com ar forçado) em músculo Semitendinosus, apresentam repetibilidade aceitável $(R \geq 0,6)$ nas medidas de força de cisalhamento.

As temperaturas de cozimento para Semitendinosus citadas por Christensen et al. (2000), variaram entre $50^{\circ} \mathrm{C}$ e $80^{\circ} \mathrm{C}$, ressaltaram que no intervalo entre $50^{\circ} \mathrm{C}$ e $60^{\circ} \mathrm{C}$ ocorreu um decréscimo na maciez do tecido que é um parâmetro mecânico importante na textura da carne. 
Em alguns países os processos de pasteurização para certos alimentos têm que satisfazer especificações legais. Nos países em que tais normas não existem, se pode calcular os processos de pasteurização adequados a partir de princípios estabelecidos com base na termodestruição dos microrganismos (Brennam, 1980). As diferenças entre o número de reduções decimais aceitos para validação do processos de pasteurização são decorrentes desta diferença. Gava (1978), por exemplo, cita que na pasteurização usa-se normalmente um tratamento $4 \mathrm{D}$, enquanto Stumbo (1965) cita uma faixa entre $5 \mathrm{D}$ e $10 \mathrm{D}$ como sendo adequada ao processo de pasteurização.

\section{7 Índices de qualidade da carne}

\subsubsection{Maciez objetiva}

A maciez da carne é um atributo de qualidade importante que afeta a aceitação de produtos cárneos pelo consumidor. Rosenthal (1999), fez uma revisão da origem do termo textura e de sua utilização na ciência de alimentos. Segundo a autora, a textura é o resultado de uma percepção global que envolve várias outras características. Incluem-se aqui os parâmetros mecânicos, geométricos, sendo que os teores de umidade e gordura não se enquadram nos anteriores, sendo avaliados separadamente.

A maciez objetiva faz parte do conjunto de parâmetros mecânicos de textura que incluem ainda a coersividade, que por sua vez se relaciona aos

parâmetros de corte, mastigabilidade, plasticidade, viscosidade, ou ainda a adesividade da carne. Os parâmetros geométricos são classificados em parâmetros de tamanho, forma da partícula e orientação das fibras (Bourne, 1982).

Os estudos sobre maciez objetiva são conduzidos com atenção especial aos componentes estruturais da carne, os processamentos pelos quais 
a carne passa e que influência estes fatores podem exercer na maciez final encontrada (Califano et al., 1997).

Inicialmente os estudos acerca da maciez eram baseados na avaliação das alterações na estrutura dos sarcômeros. Porém, esta explicação tornou-se de difícil aceitação, pois, a estrutura dos sarcômeros não difere tanto entre as espécies animais ou dentro de uma mesma espécie em diferentes grupos musculares a ponto de determinar todas as alterações na textura. A contração da estrutura miofibrilar é amplamente determinada pelo encurtamento do músculo "pós mortem", durante a conversão do músculo em carne (Harris \& Shortose, 1988). Os autores indicam também que as mudanças de força de cisalhamento ocorridas durante o rigor ou o resfriamento poderiam ser explicadas totalmente devido as mudanças na interdigitação da actina com a miosina ou pela ligação da miofibrila com o tecido conjuntivo provendo um constante nível de dureza.

Harris (1988), afirmou que a teoria da dureza baseada nos filamentos gap explica a relação da estrutura da carne com a maciez. Os "gap" filamentos são constituídos principalmente por uma proteína denominada conectina que forma parte da miofibrila cujas propriedades podem afetar a textura pela proteólise da conectina. Segundo ele, a conectina é encontrada mais na forma livre, exposta no meio, do que em arranjo ligado aos filamentos grossos. A influência dos "gap" filamentos na maciez da carne não está ainda provada, e é provável que esta teoria apresente importância apenas no animal vivo.

Sabe-se hoje que a alteração no tecido conjuntivo e nas proteínas miofibrilares são os dois fatores mais importantes correlacionados com a maciez da carne em decorrência do seu cozimento. Segundo Christensen (1999), neste processo a alteração do tecido conjuntivo se dá pelo amaciamento do colágeno em decorrência de sua gelatinização acompanhado pelo endurecimento das fibras musculares devido à coagulação das proteínas. 
As propriedades térmicas do tecido conjuntivo, principalmente do colágeno estão relacionadas com a idade do animal ao abate uma vez que a reserva este constituinte é altamente influenciada por este fator.

A desnaturação do colágeno ocorre em todos os produtos cárneos quando aquecidos. O colágeno funciona como um emulsificante, estabilizante e provavelmente como um agente de ligação e espessamento. Assim como a gelatina, o colágeno é hábil em formar alimentos geleificados (Bailey \& Ligth, 1989)

Lakkonen et al. (1970) realizaram um trabalho com o objetivo de avaliar os parâmetros maciez, capacidade de retenção de água, quantidade de componentes solúveis e $\mathrm{pH}$ em cortes de carne. Os resultados encontrados pelos autores mostraram que a obtenção de uma carne mais macia ocorreu quando no processo de cozimento foram utilizadas baixas taxas de cozimento por longo tempo. Os estudos realizados pelos autores com cozimento de porções dos músculos Longissimus, Semitendinosus e Recto femuralis, variaram entre 1 e 10 horas, em temperaturas a $60^{\circ} \mathrm{C}$. Concluíram que quanto maior o tempo de cozimento, menor é a força de cisalhamento encontrada e portanto melhor a maciez.

A respeito da maciez da carne, Harris (1988), afirmou que a decisão se a carne está ou não macia depende do processo de sua ingestão como um todo. Esta operação inclui não só os dentes, como também, a língua, o palato e os lábios. Esta decisão é tomada através da mastigação que é realizada até um ponto em que a carne posa ser engolida. Além disso, o processo é influenciado por vários outros fatores como genéticos, fisiológicos e até psicológicos.

Para a avaliação da maciez de produtos cárneos a AMSA (1995) cita os métodos físicos (também denominados objetivos) e os métodos subjetivos. Os instrumentos mais utilizados para medir os índices de textura da carne são o Instron Universal Testing Machine e o Warner Bratzler Shear Device (WBSD). Além disso, são utilizados métodos como o de tensão e compressão. $O$ princípio de funcionamento destes aparelhos baseia-se em simulações com 
instrumentos das condições às quais o alimento é submetido durante o processo de mordida. Como a avaliação da textura passa por outros critérios além deste, alguns autores dizem que é difícil estabelecer uma relação que possa refletir um grupo definido de parâmetros.

Segundo Bourne (1978), a curva que representa a relação tempoforça num aparelho de análise de perfil de textura (TPA), permite a extração de cinco parâmetros de medida e o cálculo de mais dois parâmetros extraídos destes cinco parâmetros iniciais. Estes sete parâmetros são fraturabilidade, dureza, coesividade, adesividade, elasticidade, gomosidade, mastigabilidade.

Segundo Harris (1978), o WBSD mede muito mais a tensão do que o cisalhamento. Porém, o autor se refere a avaliação da carne crua ou mal passada.

Nos métodos subjetivos são utilizados grupos de provadores treinados ou não treinados. Estes grupos variam muito de tamanho devido ao número relativamente pequeno de pessoas treinadas e à dificuldade de selecionar pessoas (Harris, 1988).

Pesquisas vêm sendo desenvolvidas há muitos anos sobre as mudanças de textura ocorridas em músculos em geral, e no Semitendinosus em particular (Hay, 1952, Laakonen et al., 1970, Shackelford et al., 1995, Palka \& Daun, 1998, Otremba et al., 1999, Lawrence et al., 2001). Os primeiros estudos conduzidos por Hay (1952) avaliaram as alterações em músculos Semitendinosus tratadas com enzimas adicionadas, com o objetivo de aumentar a maciez da carne.

\subsubsection{Relação entre a maciez objetiva e percepção sensorial da textura}

A textura de um alimento refere-se à um conjunto de percepções relativas à estrutura do mesmo, isto é, existem vários atributos relacionados com a textura dentre eles a maciez. 
A textura é uma experiência essencialmente humana resultante da interação com 0 alimento, sua estrutura e comportamento quando "manuseado". Para entender a reação diante da estrutura de um alimento e sua quebra, há o envolvimento de vários fatores fisiológicos e psicológicos da percepção de estudos físicos e químicos da composição e estrutura do componente do alimento e seu comportamento quando cortado ou comprimido (Harris, 1988).

Rosenthal (1999), cita que no passado, a maior parte dos estudos relativos a este assunto não considerava os aspectos sensoriais mas apenas, os reológicos estudados por cientistas da física, sendo os aspectos sensoriais observados por psicólogos estudantes da percepção. Nos últimos 30 anos, houve um grande avanço nesta área principalmente devido às condições técnicas proporcionadas por computadores que causaram uma convergência entre a medida física e técnicas de avaliação sensorial. A mesma autora diz que o julgamento sensorial de um alimento está relacionado a uma série de eventos que se iniciam na visualização do mesmo, passando pelo aroma, este fortemente relacionado ao cozimento, além de atributos como cor, aparência, tamanho e estrutura do alimento. Ainda segundo Rosenthal (1999), a participação direta ou indireta do analista sensorial no processo, tal como cortar e ou preparar pode também influenciar a percepção final das características sensoriais do produto.

\subsubsection{Análise descritiva quantitativa (ADQ)}

A análise descritiva quantitativa pertence ao conjunto de métodos analíticos descritivos empregados em análise sensorial juntamente com os testes de perfil. Para que seja conduzido de forma correta, faz-se necessário o cumprimento das etapas de seleção, triagem e treinamento dos avaliadores. (Damásio, 1991b) 
A seleção inicia-se com o recrutamento de forma a se escolher pessoas capazes de cumprir os objetivos dos programas de avaliação sensorial propostos. Este pode acontecer através da veiculação formal e informal de convites para a formação do grupo, com o enfoque de que é necessário que se tenha interesse em alimentos além de disponibilidade de tempo para a realização das análises. Nesta etapa são realizadas entrevistas deverão ser conduzidas de forma a se eliminar candidatos que não estejam qualificados para a tarefa (Meilgard, 1990).

Cabe ressaltar que deverão ser desqualificados aqueles candidatos que não estejam interessados ou disponíveis. Além disso, deverão ser priorizados candidatos com bom potencial como avaliador para testes de rotina e também testes especiais (AMSA, 1995).

Posteriormente faz-se a triagem daqueles mais hábeis para a tarefa através do treinamento.

De acordo com Ferreira (2000), a proposta da triagem é selecionar candidatos com acuidade sensorial normal interessados em avaliação sensorial, hábeis em discriminar e reproduzir resultados, tenham um comportamento de cooperação, prontidão e sejam motivados. É importante que sejam usados produtos cárneos para triagem nesta etapa de modo a se ter uma idéia dos procedimentos que serão realizados durante os testes definitivos. Vários modelos de testes poderão ser utilizados nesta etapa.

Uma vez tendo sido aceito o candidato passa para a etapa de treinamento, que tem como objetivos familiarizar $o$ indivíduo com os procedimentos utilizados durante a avaliação sensorial, melhorar as habilidades do mesmo para reconhecer e identificar os atributos e incrementar a sensibilidade do analista, de forma a permitir julgamentos consistentes e precisos. Para isso, é necessário um grande envolvimento do avaliador com a função. Os julgadores devem aprender a serem objetivos, analíticos e a desconsiderar seus gostos pessoais. O treinamento deve consistir na participação em testes de familiarização com os métodos, terminologia, escalas 
de classificação, fichas de avaliação, e com a variação de produtos que pode ser encontrada. (Figueredo, 2000).

Segundo a AMSA (1995), a avaliação sensorial de produtos cárneos necessita de padronizações quanto ao tamanho ideal das amostras, número de mastigações antes da emissão da avaliação, enxágüe bucal ou não entre as apresentações das amostras, tempo entre a apresentação entre uma amostra e outra. A diferenciação entre tecido conjuntivo e tecido miofibrilar é citada como uma das mais importantes pela AMSA (1995), sendo utilizado para isso amostras provenientes de espécies, cortes e idades diferentes.

Segundo Meilgard (1990), as decisões são baseadas na especificações de parâmetros relacionados com a proporção de decisões corretas tomadas pelo provador durante os testes de seleção (valor $p$ ). 


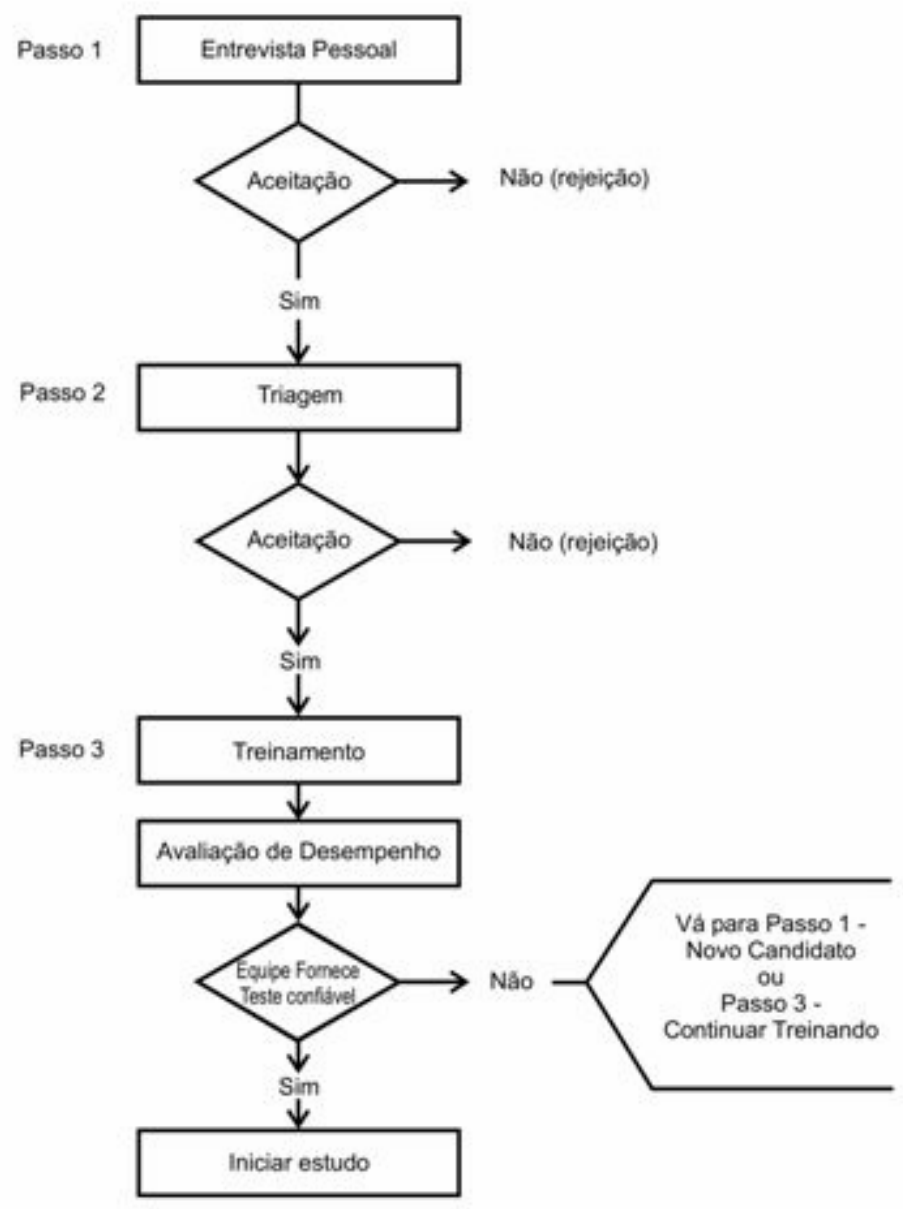

Figura 2 - Passos para selecionar uma equipe treinada

*Adaptado de American Meat Science Association (1995)

\subsubsection{Capacidade de retenção de água (CRA)}

A carne é composta por aproximadamente $75 \%$ de água, sendo as miofibrilas as principais responsáveis pela ligação entre água e proteína (Hamm, 1969). Estas são adequadas para reter a água devido a sua formação tridimensional. A quantidade de água retida depende do espaço disponível entre os filamentos (Price \& Schweigert, 1994). 
A água pode estar no músculo sob três formas: ligada, imobilizada ou livre. A primeira ocorre quando a água está fortemente associada a grupos reativos de proteínas, denomina-se água ligada. Esta é capaz de permanecer no músculo mesmo quando este é submetido a pressões externas; outras moléculas de água agrupam-se as moléculas ligadas que vão se tornando mais fracas à medida que se afastam dos grupos reativos de proteínas formando a chamada água imobilizada. A água que se mantém unida apenas por forças superficiais é denominada água livre sendo esta a que se encontra em maior quantidade no tecido muscular (Harris, 1988).

A capacidade de retenção de água (CRA) é definida por Offer (1988), como sendo a propriedade que a carne ou outros produtos cárneos possuem de reter a água própria de sua constituição durante subseqüente manipulação ou ainda aquela adicionada sob condições específicas, durante seu processamento. Os processamentos e manipulações mais comuns nestes casos são: corte, prensagem, cozimento, trituração e adição de substâncias químicas inorgânicas como sais e fosfatos.

A CRA é considerada um índice importante de qualidade, pois a quantidade de água existente na carne pode afetar seu valor comercial além de estar relacionada diretamente com as propriedades sensoriais de suculência, textura e sabor da carne.

Existem algumas metodologias para determinar a CRA de uma amostra. As mais utilizadas são o método de compressão, desenvolvido por Grau e Hamm em 1953 e o método da centrifugação desenvolvido por Hoffmann. O primeiro consiste na compressão da amostra entre duas folhas papel de filtro e posterior medida das áreas das circunferências formadas pela exsudação da amostra através de planímetro polar. O método de centrifugação consiste na separação de líquido existente na amostra através de centrifugação por tempo determinado. Além destes, existem ainda os métodos de sucção capilar, ressonância magnética e o método utilizando o forno de microondas. 
Segundo Offer e Knight (1988), os aspectos estruturais da distribuição da água no tecido muscular é um tema pouco estudado.

Hamm et al. (1983) afirmaram que nas $24 \mathrm{~h}$ posteriores a desossa, a capacidade de retenção da carne não processada ainda é considerável. Os autores afirmaram ainda que, embora este mecanismo não esteja bem esclarecido, pode-se presumir que pelo fato de neste período o músculo encontrar-se em estado de "rigor mortis", as fibras encontraram-se muito ligadas de maneira a facilitar a retenção.

\subsubsection{Suculência}

Segundo Smith (2003), a suculência da carne cozida é determinada pelo total de água intramuscular (umidade) capaz de permanecer no músculo após o cozimento . Dentre os fatores primários determinantes da suculência na carne está a capacidade de retenção de água inerente ao corte de carne em questão. Esta pode ser própria ou decorrente da adição de substâncias que porventura evitem a saída de água da massa muscular tal como os fosfatos utilizados para este fim. A quantidade de gordura intra-muscular (marmoreio) capaz de permanecer no músculo após o cozimento, também é um fator determinante na suculência da carne. Ainda segundo o autor (Smith, 2003), a suculência da carne aumenta quase que linearmente com o aumento da quantidade de gordura intramuscular existente. Com relação à carne cozida, o autor cita que a temperatura final também influencia, pois a água intramuscular é mais ou menos retida dependendo do grau de cozimento final resultante do cozimento empregado. Carnes mal passadas reterão mais água que as bem passadas. O meio de cozimento também pode influenciar a retenção da água aumentando ou diminuindo sua suculência. Quando a carne é assada forma-se uma superfície (capa) de proteína coagulada que impede a perda de suco; quanto mais rápido o processo de cozimento mais rápida será a formação dessa capa. Girard (1991), afirmou que o calor úmido é capaz de provocar 
maior perda que o calor seco, sendo tal diferença decorrente da capa superficial que se forma no entorno do produto nestas circunstâncias.

A capacidade de retenção de água da carne antes do cozimento conferirá ao músculo uma maior ou menor possibilidade de reter água. Neste caso, as carnes ditas PSE (pálida, macia e exsudativa) reterão menos líquido que as escuras, firmes e seca (Faustman \& Cassens, 1990).

A marmorização, isto é, a presença de gordura na massa muscular permite uma maior retenção de líquido aumentando por isso a suculência na carne cozida de maneira quase proporcional. Este fato faz com que os fatores suculência e marmoreio sejam fatores que incrementam a palatabilidade da carne (Price, 1994).

\subsubsection{Rendimento e perdas por cocção da carne}

Segundo Varnan (1998a), na carne crua a quantidade de água varia de acordo com vários fatores, entre eles a quantidade de gordura contida no músculo. $\mathrm{O}$ teor de água existente em uma dada musculatura decresce com o crescimento do animal, particularmente devido ao aumento do conteúdo de gordura mas ele também é visto mesmo quando expresso em conteúdo de gordura livre. $\mathrm{O}$ aumento ou diminuição do tecido conjuntivo também colabora neste processo uma vez que este é capaz de reter água. O mesmo autor diz que o processo de resfriamento das carcaças após o abate permite uma perda por evaporação de água da superfície da carne. Esta perda é estimada em cerca de $2 \%$, sendo que aproximadamente dois terços do líquido exsudado é composto por proteína.

Com o processo de cozimento ocorre um encurtamento das fibras musculares devido à perda de água que pode ser superior a $40 \%$. Este encurtamento decorrente do cozimento não só diminui o tamanho da porção de carne como também está associado com a possível diminuição na maciez da 
carne. Os diferentes tipos de cozimento da carne podem proporcionar perdas de líquido distintas no processo (Varnan,1998b).

No cozimento a seco usando ar ou irradiação, a superfície da carne pode alcançar $100^{\circ} \mathrm{C}$, mas seu interior alcança somente $60^{\circ} \mathrm{C}$ na carne considera mal passada e $80^{\circ} \mathrm{C}$ na bem passada. No processamento utilizando calor úmido, seja na água ou no vapor a temperatura total alcançada é de aproximadamente $100^{\circ} \mathrm{C}$ e com o vapor pode se manter assim por várias horas. As mudanças estruturais decorrentes do cozimento (encurtamento das fibras), ocorrem inicialmente de forma lateral e posteriormente longitudinal. Finalmente, as perdas de líquido implicam no incremento da concentração dos componentes estruturais do músculo e do tecido conjuntivo (Harris, 1985).

Segundo Offer \& Knight (1988), o teor de água na carne fresca varia de acordo com fatores como idade e a localização anatômica do músculo. Estes fatores são influenciados em última análise pelo teor de gordura existente na carne. A relação entre o conteúdo de água e o teor de gordura do músculo, segundo os mesmos autores pode chegar até a $79 \%$ água: $0 \%$ de gordura. No que diz respeito a idade os teores de água diminuem à medida que a idade aumenta, ainda que sejam calculados em base livre de gordura. Parte do declínio, segundo os autores, se dá devido à diminuição progressiva do tecido conjuntivo com o aumento da idade. Este tecido conjuntivo é possuidor de maior quantidade de água que o tecido muscular. A diminuição ocorre concomitantemente com o crescimento da porcentagem de fibra muscular.

Com o processo de cozimento há um encurtamento evidente nos músculos devido dentre outros fatores à grande perda de líquidos ocorrida que normalmente ultrapassa $40 \%$. Tsai \& Ockerman (1981) citam que em uma carne "mal cozida" a teor de umidade final obtido é de aproximadamente $70 \%$. Os autores citam ainda que quando o processo de cozimento produz uma carne "bem cozida" este teor pode chegar a $50 \%$.

Sob o ponto de vista estrutural, Offer \& Knight (1988) afirmam que quando um produto é aquecido, as moléculas de miosina se ligam formando um 
a espécie de gel que permite uma maior adesão entre as miofibrilas. Existem autores que argumentam que este gel de miosina é o principal responsável pela capacidade de retenção da água em produtos cozidos. Apesar de na carne crua a capacidade de retenção da água estar relacionada principalmente com a miofibrila constituinte do tecido muscular, ao ser submetida ao processo de cozimento ocorre a formação de géis na matriz tecidual como um todo.

Este processo influencia não só o tamanho da porção, como também, a maciez da carne.

\subsubsection{Sabor}

A textura tem raízes físicas e o sabor tem raízes químicas (Szczezniak,1998). Segundo Ferreira (2000), o sabor é uma experiência mista, mas unitária de sensações olfativas, gustativas e táteis percebidas durante a degustação. O sabor é influenciado pelos efeitos táteis, térmicos ou cinestésicos.

A carne crua apresenta um aroma mais leve que a carne quando cozida, aroma este devido á presença do ácido lático. Existem variações no aroma da carne crua que estão relacionados ao sexo, idade e espécie do animal em questão.

O aroma da carne cozida é afetado por fatores além daqueles que afetam a carne crua. São eles o método de cozimento e os possíveis tratamentos aos quais a carne foi submetida antes de ser processada tais como: adição de temperos, amaciamento ou tenderização química.

A carne cozida é um dos aspectos menos conhecidos na pesquisa científica, sendo por isso muito importantes uma vez que constituem-se numa possibilidade de anular as características sensoriais indesejáveis decorrentes das variações naturalmente existentes na carne (Price e Schweigert, 1984).

Segundo Mottram (1998), o aquecimento é capaz de produzir aromas e sabores na carne muito distintos daqueles existentes na carne crua. $\mathrm{O}$ autor 
cita que durante esse processo, ocorrem uma série de reações termicamente induzidas entre os compostos não voláteis da carne e o tecido adiposo resultando num grande número de produtos.

Embora o sabor da carne cozida seja influenciado por compostos que contribuem com as sensações gustativas, é o composto volátil formado durante o cozimento que determina o aroma e contribui para a maioria das características que formam o sabor da carne em última instância (Mottram, 1998).

Com o aquecimento, ocorre a reação de "Maillard" entre aminoácidos e açúcares redutores existentes na carne, além da degradação térmica dos lipídeos. Estas são as maiores contribuições ao aroma encontradas na carne cozida.

Os objetivos deste trabalho foram verificar se existe diferença entre atributos de qualidade e entre os rendimentos encontrados em músculos Semitendinosus cozidos à temperatura de $70^{\circ} \mathrm{C}$ e $80^{\circ} \mathrm{C}$, de forma a se obter um produto seguro sob o ponto de vista microbiológico.

Utilizou-se tachos industriais para o cozimento com água e estufa para cozimento a vapor.

O rendimento foi avaliado através das perdas por cozimento. Os atributos de qualidade analisados foram a Capacidade de Retenção de Água (CRA) e a maciez objetiva. De posse dos resultados da avaliação sensorial, procurou verificar em que medida o atributo maciez influenciou os atributos presença de tecido conjuntivo, colágeno e sabor. 


\section{MATERIAL E MÉTODOS}

O experimento foi realizado na planta piloto do Centro de Tecnologia de Carnes (CTC) do Instituto de Tecnologia de Alimentos (ITAL) localizado em Campinas, SP.

\subsection{Matéria-prima}

A matéria-prima foi constituída de cortes de "Lagarto" (Semitendinosus), não maturados, sendo as amostras provenientes de um único processador, e os animais abatidos da raça Nelore, provenientes de animal macho, com idade aproximada de 3,5 anos. Procurou-se obter cortes com o peso o mais próximo possível entre si de modo a se alcançar padronização nas amostras.

Os cortes já foram adquiridos limpos, sem tecido conjuntivo adjacente, sendo resfriados e mantidos neste estado em caixas plásticas na câmara de resfriamento até o momento do processamento em temperatura de $0^{\circ} \mathrm{C}$.

\subsection{Testes preliminares}

Os testes preliminares foram realizados com o objetivo de verificar o comportamento do músculo Semitendinosus em relação à maciez e as perdas por cozimento resguardando a segurança microbiológica do produto através do cozimento a temperatura utilizada. Com base na literatura sobre o tema, foram 
escolhidas conjugações de tempo de cozimento do produto, temperatura interna das amostras, temperatura do meio de cozimento.

Procurou-se buscar uma conjugação de tempo-temperatura em diferentes meios de cozimento (água e vapor) capaz de resultar num produto viável com relação aos critérios maciez, efetividade e segurança microbiológica obtida através do tratamento térmico. Por se tratar de uma etapa preliminar, o comportamento das amostras no quesito maciez objetiva foi medido através do aparelho TA-XT 2i utilizando acessório Warner Braztler Shear $(3 \mathrm{~mm}$ de espessura) e as seguintes especificações: velocidade de $20 \mathrm{~cm} / \mathrm{min}$. Foram realizadas duas repetições para cada tratamento. As amostras foram cortadas em cilindros de $1,27 \mathrm{~cm} \times 2,00 \mathrm{~cm}$, sendo cisalhadas ao longo do diâmetro.

\subsection{Processamento}

Após terem sido padronizados em peso e tamanho as amostras foram distribuídas de forma aleatória, pesadas e analisadas quanto ao $\mathrm{pH}$.

Em seguida, as peças foram embaladas a vácuo, em embalagem do tipo "cook in", marca Cryovac CN614 na forma de sacos encolhíveis com alta barreira de oxigênio resistente a temperaturas de cozimento, utilizadas na indústria de alimentos para embalar presunto a ser cozido.

O cozimento foi realizado utilizando-se dois meios de cozimento :

1- Vapor: feito em estufa para cozimento e cozimento com circulação de vapor, marca Beker modelo Dr-Kompakt capacidade para $2300 \mathrm{~L}$;

2- Água: tachos com capacidade de $100 \mathrm{~L}$ de aço inox de dupla camisa com cozimento interno.

As temperaturas analisadas foram de $70^{\circ} \mathrm{C}$ e $80^{\circ} \mathrm{C}$ tanto para água quanto para vapor. O objetivo foi atingir esta temperatura no ponto frio da amostra. Um termopar de agulha tipo $\mathrm{T}$ contendo dois sensores foi utilizado para medir as variações de temperatura do experimento. Um sensor foi inserido no ponto frio de uma das amostras e outro permaneceu no meio de cozimento 
(água ou vapor) com o mesmo objetivo. O referido equipamento foi conectado a um termômetro digital marca ECB. As temperaturas encontradas nos diferentes pontos em questão (amostra e ambiente), foram registradas a cada 2 minutos durante o processo de cozimento (apêndice). Após atingida a temperatura desejada, as amostras foram retiradas do meio de cozimento e resfriadas em água fria corrente até que alcançassem $35^{\circ} \mathrm{C}$, quando foram pesadas e armazenadas a $0^{\circ} \mathrm{C}$ por $24 \mathrm{~h}$ até o início da realização das análises.

\subsection{Análises físico-químicas}

\subsection{1 pH}

A medição foi feita nas amostras cruas, antes do processamento, através de potenciômetro de punção da marca Cole-Parmer - Oakton. A medição ocorreu em três pontos (inicial, mediano e final) de cada uma das amostras, tanto na superfície quanto internamente. Na região externa o eletrodo foi colocado em contato direto com a superfície da amostra. Para a efetivação das medições internas foi feita uma pequena perfuração de dois $(2) \mathrm{cm}$ onde o eletrodo foi inserido de forma a ficar em contato com a parte interna da musculatura. Os resultados correspondem à média encontrada nessas medições, tendo sido separado as médias externas das internas.

Os teores de umidade, cinza total (ou resíduo mineral fixo), proteínas, e gorduras foram analisados utilizando-se a metodologia descrita pela AOAC (1995). O teor de carboidratos foi calculado por diferença [100 - (cinza + proteína + umidade)].

\subsection{Avaliação do processo de cozimento}

A letalidade total tendo como microrganismo de referência 0 Clostridium botulinum tipo $\mathrm{E}$ obtida nos processamentos em cada tratamento 
realizado foi calculada através da utilização do método genérico descrito a seguir:

Inicialmente foi construída a curva de penetração de calor nas amostras, utilizando-se a fórmula $10^{(X-Y) / Z}$, onde $X$ foi a temperatura no ponto frio da amostra em cada intervalo medido $(2 \mathrm{~min}), \mathrm{Y}$ foi a temperatura de referência para cada tratamento $\left(70^{\circ}\right.$ ou $\left.80^{\circ}\right)$ e $Z$ foi a taxa letal do microrganismo $\left(8,8^{\circ} \mathrm{C}\right)$. A letalidade foi calculada em cada intervalo de tempo analisado, sendo em seguida realizado o somatório das letalidades a cada intervalo, encontrando-se a letalidade total.

Para cálculo do valor de pasteurização $(P)$, utilizou-se o somatório das contribuições letais (letalidade total) de cada estágio de temperatura multiplicada pelo intervalo de tempo em que cada temperatura foi medida ( 2 $\min )$.

O número de reduções decimais obtidos durante o processamento foi calculado através da divisão do valor $P$ encontrado dividido pelo valor $D$ ajustado para a cada uma das temperaturas de $70^{\circ} \mathrm{C}$ e $80^{\circ} \mathrm{C}$ em cada tratamento, tanto na água quanto no vapor. Como os valores padrões para o microrganismo de escolha foram calculados com base em uma temperatura teste de $82,2^{\circ} \mathrm{C}$, foi necessário fazer um reajuste para a realização dos cálculos nas temperaturas utilizadas no experimento, isto é, $70^{\circ} \mathrm{C}$ e $80^{\circ} \mathrm{C}$. Isto foi feito através da fórmula $\mathrm{D} 1 / \mathrm{D} 2=10^{(\mathrm{T} 2-\mathrm{T} 1) / 2}$, onde:

$D_{82,2}=0,1-3,0$ e $Z=5,0-8,8$

$D_{80}=5,33$ para temperatura de $80^{\circ} \mathrm{C}$

$D_{70}=73,3$ para temperatura de $70^{\circ} \mathrm{C}$

\subsection{Análises microbiológicas}

Para a caracterização microbiológica das amostras cruas foram feitas as análises de Clostrídeos sulfito redutores, mesófilos, psicrótróficos aeróbios e Salmonella sp. 
Após o cozimento, as análises efetuadas foram: Salmonella sp, Clostrídeos sulfito redutores e psicrotróficos aeróbios. Todas as análises microbiológicas seguiram a metodologia descrita por Vanderzant e Splittstoesser (1992).

\subsection{Análises físicas}

\subsubsection{Perdas durante a cocção}

Foram avaliadas as perdas referentes à exsudação ocorrida durante a cozimento das amostras. Para a realização do cálculo destas perdas, foi utilizada a seguinte fórmula: [(peso da amostra crua - peso da amostra cozida)/peso da amostra crua] x 100, sendo o resultado expresso em unidades percentuais.

Observando-se as perdas nos dois processos utilizados foram calculados os rendimentos no tratamento térmico nas duas situações (com ar e a água).

\subsubsection{Capacidade de retenção de água}

A metodologia utilizada foi a descrita por Grau \& Hamm (1953) e modificada por Hoffmann et al. (1982). Esta se baseia na pesagem acurada de 0,5 $\mathrm{g}$ de carne em papel filtro que posteriormente foram prensados entre duas placas de "plexiglass" a 500 psi por $1 \mathrm{~min}$. Posteriormente, foi medida a área da circunferência formada pela impressão deixada pela amostra após a prensagem e a área do halo que corresponde a marca impressa no papel filtro resultante da exsudação da amostra. A divisão entre estas áreas (interna e externa), corresponde à capacidade de retenção de água que a amostra possui. Para efetuar as medidas utiliza-se um planímetro polar. 


\subsubsection{Medida da maciez objetiva através do teste de avaliação da força de cisalhamento}

As condições de estrutura, consistência e textura da carne, foram medidas fisicamente no texturômetro (TA-XT 2i) acoplado à lâmina Warner Braztler) através da análise de força de cisalhamento e subjetivamente através da análise sensorial.

As amostras, após o processamento, foram armazenadas na câmara fria em temperatura de $0^{\circ} \mathrm{C}$, até o momento da realização das análises., no dia posterior a cozimento das amostras. Para a realização da medição física de um músculo constituinte da unidade amostral, foram retirados bifes com $2 \mathrm{~cm}$ de espessura no sentido transversal às fibras musculares das porções inicial, mediana e final. Em cada bife foram retiradas 10 amostras cilíndricas tendo como medidas finais $1,27 \mathrm{~cm} \times 2,0 \mathrm{~cm}$ cortados no sentido paralelo à fibra muscular (AMSA, 1995), utilizando -se para isso um vazador adaptado a uma furadeira. A determinação da textura foi feita submetendo-se cada amostra ao teste da força de cisalhamento utilizando-se o texturômetro TA-XT 2i acoplado à lâmina Warner Braztler.

\subsection{Avaliação sensorial}

Análise sensorial foi realizada utilizando-se teste quantitativo para os atributos: maciez, suculência, presença de colágeno e sabor. Este foi conduzido no Laboratório de Análise Sensorial do ITAL-Centro de Tecnologia de Carnes, com equipe de sete a treze julgadores treinados, mostrando bom poder discriminativo ( $p_{\text {Famostra }}<0,30$ ), boa reprodutibilidade nos julgamentos ( $\left.p_{\text {Frepetiçoes }}>0,05\right)$ e consenso com os demais membros da equipe (Damásio, 1991c). Trata-se de uma equipe treinada do próprio CTC. Foi feita uma atualização do treinamento, objetivando uma maior familiarização com os procedimentos do teste, melhorando a habilidade em reconhecer e identificar os 
atributos sensoriais em questão de forma a se produzir resultados válidos e seguros.

O CTC-ITAL dispõe de cabines computadorizadas individuais para teste, controle de iluminação e de temperatura ambiente, bem como as demais características citadas em Damásio (1991a).

Foi utilizada iluminação verde na área das cabines para se mascarar a aparência das amostras, facilitando a avaliação sem tendências, dos atributos em estudo. Após as amostras serem retiradas das câmaras de resfriamento a temperatura de $0^{\circ} \mathrm{C}$, foram levadas ao laboratório de análise sensorial, sendo então aquecidas em fornos elétricos até atingir temperatura interna de $50^{\circ} \mathrm{C}$. Em seguida as amostras foram cortadas em unidades de $3 \mathrm{~cm} \times 3 \mathrm{~cm}$ de altura (sem crostas). Foram mantidas aquecidas à aproximadamente $40^{\circ} \mathrm{C}$ em estufa da marca Metalúrgica Borges, modelo de quatro divisões. As amostras aquecidas foram servidas em recipientes plásticos descartáveis, acompanhadas de: palitos de madeira ; meia fatia de pão de forma e água para enxágüe bucal. Foram apresentadas quatro amostras sendo cada duas pertencentes a um mesmo tratamento, sendo codificadas com números de três dígitos escolhidos de forma casualizada. A ordem com que as amostras foram servidas foi definida de forma aleatória. Foram servidas 2 amostras por sessão e o delineamento estatístico utilizado foi o de blocos completos com relação aos julgadores. Para avaliar a intensidade de cada atributo nas amostras, foi utilizada escala estruturada de $10 \mathrm{~cm}$. conforme ficha apresentada na Figura 3. Os dados foram coletados utilizando-se sistema informatizado da Compusense Inc., Canadá, versão 4.2. A ficha utilizada na avaliação sensorial foi a seguinte: 


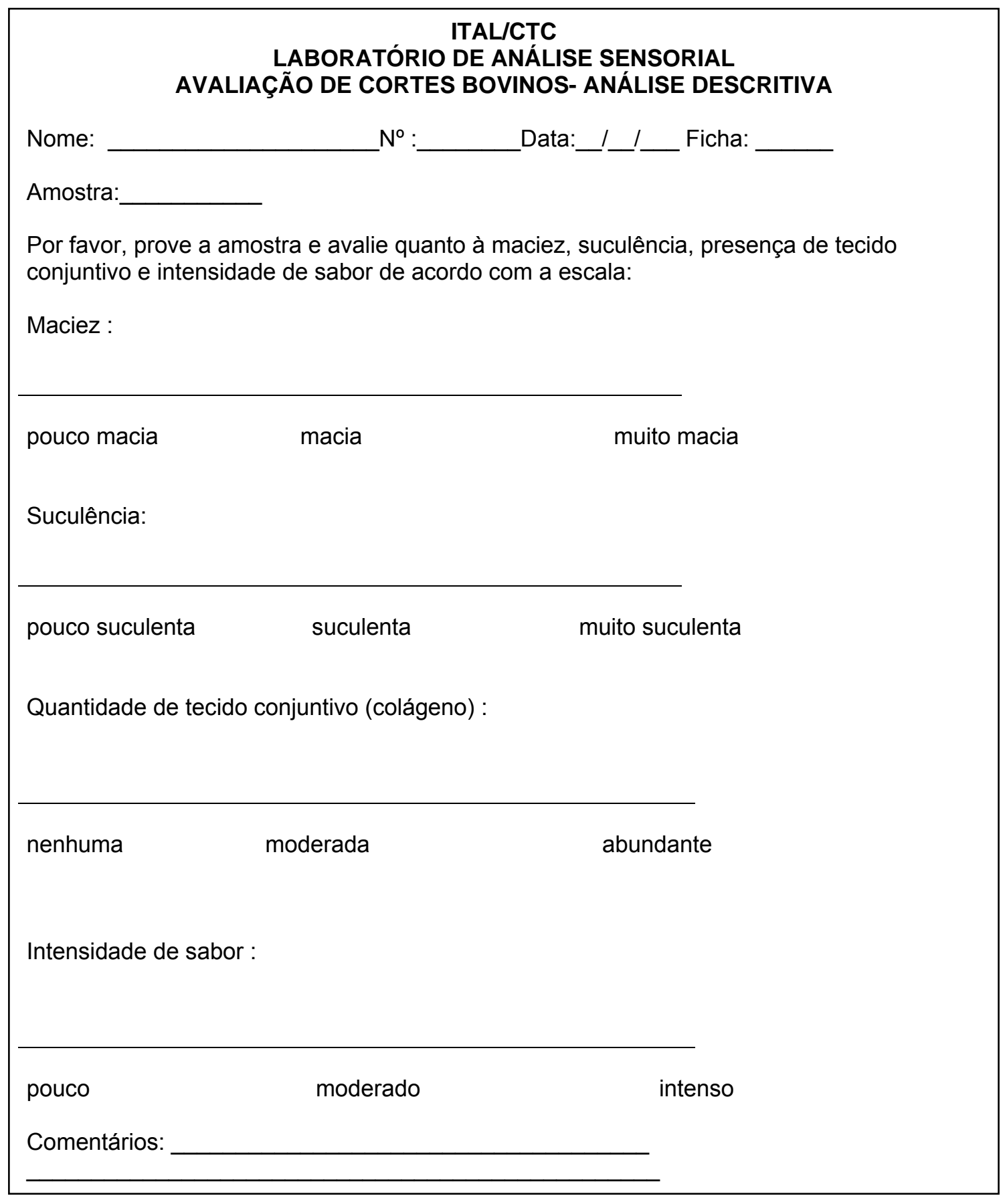

Figura 3 - Ficha utilizada na avaliação sensorial 


\subsection{Delineamento experimental}

Foram empregados dois fatores: temperatura e meio de cozimento. Os níveis testados para temperatura foram $70^{\circ} \mathrm{C}$ e $80^{\circ} \mathrm{C}$ e para o meio de cozimento água e vapor. Os experimentos foram realizados seguindo um planejamento fatorial $2^{2} \mathrm{com}$ duas repetições.

A unidade amostral foi constituída de três cortes do músculo Semitendinosus.

As avaliações de processo de cozimento, físico-químicas $(\mathrm{pH}$ da carne crua, composição centesimal) e microbiológicas foram realizadas utilizando-se as médias encontradas nos dois processamentos. As perdas por cozimento, maciez objetiva e capacidade de retenção de água, foram analisadas utilizando-se testes de médias através do teste T. Para cada uma destas variáveis posteriormente foi feito:

1 - Modelo fatorial - utilizando-se os dois fatores meio de cozimento e temperatura foram avaliados os efeitos da variação dos tratamentos sendo as as variáveis resposta a CRA, as perdas por cozimento e a maciez objetiva.

2 - Teste de Tukey - para a avaliação da efetividade do processo de cozimento e para o tempo de cozimento .

3 - A análise sensorial foi avaliada pelo Teste de Correlação de Pearson utilizando-se nível de confiança de 99\%, objetivando saber a correlação entre os atributos. Posteriormente foi elaborada uma regressão linear múltipla tendo como referência o quesito maciez.

\subsection{Análises estatísticas}

Foi empregado o programa estatístico SPSS para o a Análise Univariada (teste de médias), Teste de Correlação de Pearson e Regressão Linear Múltipla. 


\section{RESULTADOS E DISCUSSÃO}

Neste trabalho foram realizadas as seguintes análises:

Na carne crua:

$-\mathrm{pH}$

- Caracterização microbiológica

Na carne cozida:

- Composição centesimal

- Avaliação do processo de cozimento

- Análises microbiológicas

- Avaliação das perdas por cozimento

- Capacidade de retenção de água

- Maciez objetiva

- Avaliação sensorial

Os atributos analisados na avaliação sensorial foram: presença de colágeno, suculência, sabor e maciez. O objetivo da avaliação sensorial foi verificar as correlações existentes entre os atributos nas amostras submetidas ao tratamento de $80^{\circ} \mathrm{C}$ (tanto em água quente-tacho quanto em vapor - estufa) visto que o tratamento utilizando $70^{\circ} \mathrm{C}$ não alcançou a letalidade necessária para pasteurização tendo como microrganismo alvo o Clostridium botulinum tipo E. 


\subsection{Análises físico-químicas}

$\mathrm{O} \mathrm{pH}$ encontrado na carne crua antes do processamento variou entre 5,4 e 5,7 internamente e 5,5 e 6 externamente, concordando com os valores citados por Prandl et al. (1994a), uma vez que este nível de acidificação é o que proporciona boas propriedades tecnológicas para os produtos exceto quando se deseja a elaboração de embutidos.

A carne utilizada neste experimento não foi maturada o que pode ter contribuído para os resultados de $\mathrm{pH}$ e rendimentos encontrados de acordo com as perdas por cozimento.

Segundo Girard (1991), a única característica da carne que influencia realmente as perdas por cozimento e conseqüentemente o rendimento da carne cozida é o pH da mesma no momento do processamento. $\mathrm{O}$ autor afirma que as variações de $\mathrm{pH}$ estão relacionadas com as condições de pré-abate e abate, e os tratamentos pós-mortem como o grau de maturação.

\subsection{Composição centesimal}

A Tabela 3 mostra a composição centesimal das amostras de carne cozida.

A composição centesimal citada pelo USDA (2004), citada na Tabela 1 não especifica os cortes utilizados para a análise talvez as diferenças sejam decorrentes deste fato. No caso do Semitendinosus, utilizado neste experimento, a composição centesimal se aproxima mais daquela citada por Franco (2002).

O músculo Semitendinosus é considerado um corte de carne com características muito diferenciadas se comparadas aos outros. Além disso, os meios pela as análises feitas pelo USDA (2004), são bastante diferentes daqueles utilizados neste trabalho. 
O presente trabalho concorda com os teores de proteínas citados por Franco (2002). Com relação aos carboidratos totais, estes são inexistentes na proteína animal, sendo os resultados são concordantes tanto com Franco (2002), quanto com o USDA (2004). A gordura foi o constituinte que apresentou teores muito baixos em relação ao encontrado na literatura. Os métodos de cozimento assim como as temperaturas utilizadas no experimento podem ser a razões da diferença (o autor não cita o método utilizado). Além disso, os teores mais altos de gordura nas amostras cozidas a $70^{\circ} \mathrm{C}$ provavelmente se devam à menor perda deste componente durante a cozimento devido à natureza desta substância. Somente o tratamento utilizando $80^{\circ} \mathrm{C}$ em água apresentou $1 \%$ a mais de proteína com relação aos outros. As principais alterações protéicas provocadas pelo cozimento térmico dizem respeito à sua desnaturação da proteína miofibrilar, especialmente a miosina. Este processo pode se iniciar à temperatura de $40^{\circ} \mathrm{C}$, sendo que o colágeno necessita de temperaturas mais elevadas para que inicie seu processo de desnaturação (Christensen, 2000). Portanto, estas alterações são de natureza essencialmente qualitativa daí não haver diferença nos teores protéicos encontrados no presente experimento. Que diferença existe entre umidade, Com relação ao teor de cinzas encontrado na avaliação da composição centesimal os dados do USDA (2004) e de Franco (2002) não utilizam a metodologia de incineração em mufla, inviabilizando por isso, a comparação entre os resultados citados pela literatura e aqueles encontrados neste experimento. 
Tabela 3. Composição centesimal das amostras cozidas em cada tratamento

\begin{tabular}{lcccc}
\hline \multicolumn{5}{c}{ Tratamentos } \\
\hline & Água $70^{\circ} \mathrm{C}$ & Vapor $70^{\circ} \mathrm{C}$ & Água $80^{\circ} \mathrm{C}$ & Água $80^{\circ} \mathrm{C}$ \\
\hline Umidade* $^{*}$ & $67,68 \pm 0,3^{* *}$ & $65,56 \pm 0,24$ & $70,03 \pm 0,18$ & $69,78 \pm 0,07$ \\
Lipídeos* $^{*}$ & $2,75 \pm 0,09$ & $2,63 \pm 0,74$ & $1,47 \pm 0,04$ & $1,43 \pm 0,05$ \\
Proteínas $^{*}$ & $27,3 \pm 1,08$ & $27,67 \pm 0,74$ & $28,72 \pm 1,00$ & $27,66 \pm 0,53$ \\
Cinza* & $1,21 \pm 0,03$ & 1,11 & 1,15 & $1,24 \pm 0,03$ \\
Carboidratos & $0,36 \pm 0,01$ & $0,36 \pm 0,01$ & 0 & 0 \\
totais* & & & & \\
\hline
\end{tabular}

* média de 2 repetições (6 amostras em cada processamento)

** desvio padrão da média

\subsection{Avaliação do processo de cozimento}

Não houve diferença significativa entre os tempos de cozimento considerando os tratamentos aplicados (Tabela 4).

Com relação ao número de reduções decimais encontradas nos tratamentos utilizados, verificou-se que o tratamento utilizando $80^{\circ} \mathrm{C}$ foi significativamente diferente $(P<0,05)$ do tratamento utilizando-se $70^{\circ} \mathrm{C}$, sendo que o tratamento de $80^{\circ} \mathrm{C}$ permitiu uma redução compatível com o processo de pasteurização tendo como microrganismo alvo o Clostridium botulinum tipo $\mathrm{E}$ (valores $\mathrm{D}=5,33$ para temperatura de $80^{\circ} \mathrm{C}$ e $\mathrm{D}=73,3$ para temperatura de $\left.70^{\circ} \mathrm{C}\right)$.

O resultado encontrado no presente trabalho concorda com aqueles encontrados por Lawor et al. (2000). Os autores realizaram experimento com cozimento de carne de peru e posterior inoculação do alvo o Clostridium botulinum $\mathrm{B}$, e observaram que a temperatura de $72,2^{\circ} \mathrm{C}$ não foi capaz de 
eliminar o microrganismo alvo. Este microrganismo apresenta um valor $D=0,1$ 0,2 que é mais baixo que o valor $D$ necessário para a eliminação do Clostridium botulinum $\mathrm{E}$ (valor $\mathrm{D}=0,3-3$ ). Cabe ressaltar que o tempo de cozimento total realizado pelos autores foi de 6 horas, em três estágios. Verifica-se, com isso, que a temperatura de $70^{\circ} \mathrm{C}$ mesmo que aplicada por longo período pode ser considerada pouca para se obter índices satisfatórios de pasteurização com relação ao $C$. botulinum.

Com relação a efetividade do processo de pasteurização no tratamento com temperaturas de $80^{\circ} \mathrm{C}$, tanto em água quanto em vapor, observa-se que as reduções decimais alcançadas foram consideradas compatíveis com o desejado para o processo de pasteurização.

Califano et al. (1997), com o objetivo de estudar os efeitos das condições de processamento na dureza da carne, aqueceram porções de músculo Semitendinosus tendo como temperatura final no interior da amostra a ser alcançada $68^{\circ} \mathrm{C}$ e meio de cozimento $70^{\circ} \mathrm{C}$. O tempo necessário para alcançar seu objetivo foi de 144 min., tempo médio similar ao alcançado neste trabalho (Tabela 4).

Rybka et al. (2001) avaliando as características de armazenamento de 14 produtos comerciais cozidos dentre eles, o "roast beef" em embalagens do tipo "cook in" encontrou uma redução de $12 \mathrm{D}$ para esporos de C. botulinum não proteolítico utilizando temperatura de $80^{\circ} \mathrm{C}$ durante 255 min. e mantendo em baixas temperaturas de armazenamento. Este resultado foi considerado pelos autores como sendo satisfatório e concorda com os resultados encontrados neste trabalho, porque segundo Stumbo (1965), para o processo de pasteurização é necessário que ocorra uma redução decimal entre 5 e 10 ciclos logarítmicos.

Tendo como referência estas duas, as amostras cozidas com temperatura de $70^{\circ} \mathrm{C}$ não alcançaram o número de reduções decimais compatível com o desejado para o processo de pasteurização (Tabela 4). 
Tabela 4. Tempo total de cozimento e número de reduções decimais alcançadas em cada um dos tratamentos

\begin{tabular}{|c|c|c|c|c|c|c|c|}
\hline \multirow[t]{3}{*}{ Tratamento } & \multirow[t]{3}{*}{$\mathrm{N}^{* *}$} & \multicolumn{3}{|c|}{$\begin{array}{l}\text { Tempo total de cozimento } \\
\qquad(\mathrm{min})\end{array}$} & \multicolumn{3}{|c|}{$\begin{array}{c}N^{0} \text { de reduções decimais } \\
\text { alcançadas }\end{array}$} \\
\hline & & \multicolumn{2}{|c|}{ Processamento* } & \multirow[t]{2}{*}{ Média } & \multicolumn{2}{|c|}{ Processamento* } & \multirow[t]{2}{*}{ Média } \\
\hline & & 1 & 2 & & 1 & 2 & \\
\hline Água $70^{\circ} \mathrm{C}$ & 3 & 136 & 108 & $122^{a}$ & 0,33 & 0,7 & $0,51^{b}$ \\
\hline Vapor $70^{\circ} \mathrm{C}$ & 3 & 138 & 106 & $122^{a}$ & 0,79 & 0,66 & $0,73^{b}$ \\
\hline Água $80^{\circ} \mathrm{C}$ & 3 & 106 & 100 & $103^{a}$ & 10,34 & 12,23 & $11,29^{c}$ \\
\hline Vapor $80^{\circ} \mathrm{C}$ & 3 & 100 & 114 & $107^{a}$ & 8,33 & 11,91 & $10,12^{c}$ \\
\hline
\end{tabular}

*Processamento 1 e 2 referem-se às duas replicações realizadas no experimento

${ }^{* *} \mathrm{~N}=$ número de amostras

Nota: letras iguais na coluna vertical indicam que não houve diferença significativa entre os tratamentos em nível de 95\%

\subsection{Avaliação microbiológica}

\subsubsection{Carne crua}

As análises de caracterização microbiológica das amostras da carne crua foram realizadas no dia do processamento, na chegada das amostras. Os resultados encontram-se na Tabela 5.

$O$ índice $1 \times 10^{6} \mathrm{UFC} / \mathrm{g}$ é citado pela International Comission on Microbiological Specifications for Foods (ICMSF, 1980) como o limite máximo 
aceitável de microrganismos mesófilos em carne crua. A qualidade microbiológica das amostras de carne crua contendo $1 \times 10^{8}$ UFC de bactérias mesófilas por grama de amostra é citada por Nurmi e Ring (1999) como sendo inviável para consumo humano, uma vez que nesta condição a carne entra em estado de deterioração. Os mesmos autores citam ainda que com uma contagem de $1 \times 10^{7} \mathrm{UFC} / \mathrm{g}$ de carne crua tendo em vista os microrganismos em geral, esta não se encontra em condições de ser utilizada como matériaprima. Sendo assim, os resultados descritos na Tabela 5 apontam uma boa qualidade microbiológica das amostras, pois estão abaixo dos utilizados como referência na literatura. 
Tabela 5. Valores médios da caracterização microbiológica da carne crua nas duas replicações do experimento

\begin{tabular}{lcccc}
\hline & $\mathrm{N}^{*}$ & Processamento $1^{* *}$ & ${\text { Processamento } 2^{* *}}^{*}$ & Média \\
\hline $\begin{array}{l}\text { Psicrotróficos } \\
\text { aeróbios } \\
\left(\log { }_{10} \text { UFC/g) }\right.\end{array}$ & 3 & 1,68 & 1,62 & 1,65 \\
\hline $\begin{array}{l}\text { Psicrotróficos } \\
\text { anaeróbios } \\
\left(\log { }_{10} \text { UFC/g) }\right.\end{array}$ & 3 & 4,0 & 3,66 & 3,83 \\
$\begin{array}{l}\text { Mesófilos } \\
\left(\log { }_{10} \text { UFC/g) }\right.\end{array}$ & 3 & 1,63 & 1,66 & 1,64 \\
$\begin{array}{l}\text { Salmonellla spp. } \\
\text { em } 25 g .\end{array}$ & 3 & Ausente & Ausente & Ausente \\
$\begin{array}{l}\text { Clostrídios sulfito } \\
\text { redutores } \\
\text { (log } 10 \text { UFC/g) }\end{array}$ & 3 & $<1$ & $<1$ & $<1$ \\
\hline
\end{tabular}

* $\mathrm{N}=$ número de amostras em cada processamento

** Processamento 1 e 2 referem-se às duas replicações realizadas no experimento

Nota: a coleta de amostras objetivando a caracterização microbiológica da carne crua foi realizada no conjunto dos músculos, não levando em consideração os tratamentos posteriores

\subsubsection{Avaliação microbiológica da carne cozida}

No dia posterior ao processamento foram realizadas as seguintes análises: Clostrídeos sulfito redutores, Salmonella $s p$, e contagem total de microrganismos psicrotróficos aeróbios e anaeróbios. Os resultados encontramse na Tabela 6. 
Avaliando-se a Tabela 6 observa-se que o processamento eliminou a presença dos microrganismos psicrotróficos aeróbios existentes na carne processada. Além disso, a embalagem a vácuo e a conservação em temperatura de $0^{\circ} \mathrm{C}$, proporciona uma proteção adicional no que diz respeito à microrganismos psicrotróficos aeróbios.

O processamento térmico realizado no experimento permitiu a eliminação dos microrganismos psicrotróficos anaeróbios viáveis nas amostras. Este é um resultado esperado, uma vez que a contagem inicial realizada por ocasião da caracterização microbiológica das amostras apresentou-se baixa, com relação a estes microrganismos. Alem disso, o processo de pasteurização utilizando a temperatura de $80^{\circ} \mathrm{C}$ se mostrou eficaz para a inativação de possível presença do microrganismo alvo

Os microrganismos Salmonella sp. e Clostrídeos sulfito redutores não foram encontrados na matéria-prima crua, não tendo havido portanto nenhuma alteração com relação à sua presença no produto cozido.

Assim como no presente experimento, a contagem total realizada por Rybka et al. (2001) para microrganismos psicrotróficos anaeróbios obteve resultados indetectáveis segundo o autor por um período de até 56 dias de armazenamento. Os autores concluíram que na maioria dos produtos avaliados, as mudanças nos atributos de qualidade antecedem as alterações nas contagens microbianas consideradas padrão.

Os presentes resultados concordam com aqueles encontrados por Nyati (2000). O autor processando carne bovina a $70^{\circ} \mathrm{C}$ por 278 min. não alcançou uma redução logarítimica compatível o processo de pasteurização por ele desejado, o que o levou a concluir que esta temperatura não é recomendada para obtenção de pasteurização em produtos cárneos cozidos, no que diz respeito ao $C$. botulinum não proteolítico.

Com relação à contagem de microrganismos psicrotróficos anaeróbios Nyati (2000), encontrou um número menor que $10 \mathrm{UFC/g}$ de amostra, resultado este concordante com os encontrados no presente trabalho. 
Tabela 6. Valores médios da caracterização microbiológica da carne cozida nas duas replicações do experimento no dia posterior ao processamento

\begin{tabular}{|c|c|c|c|c|}
\hline \multicolumn{5}{|c|}{ Tratamentos } \\
\hline & Água $70^{\circ} \mathrm{C}$ & Vapor $70^{\circ} \mathrm{C}$ & Água $80^{\circ} \mathrm{C}$ & Vapor $80^{\circ} \mathrm{C}$ \\
\hline $\begin{array}{l}\text { Psicrotróficos } \\
\text { aeróbios } \\
\left(\log _{10} \mathrm{UFC} / g\right)\end{array}$ & $<1$ & $<1$ & $<1$ & $<1$ \\
\hline $\begin{array}{l}\text { Psicrotróficos } \\
\text { anaeróbios }\end{array}$ & 0 & 0 & 0 & 0 \\
\hline$\left(\log _{10}\right.$ UFC/g) & 0 & 0 & 0 & 0 \\
\hline $\begin{array}{l}\text { Clostrídeos sulfito } \\
\text { redutores (log } \\
{ }_{10} \mathrm{UFC} / \mathrm{g} \text { ) }\end{array}$ & 0 & 0 & 0 & 0 \\
\hline
\end{tabular}

\subsection{Capacidade de retenção de água}

A Tabela 8 mostra os resultados da capacidade de retenção de água encontrados na carne cozida em cada um dos tratamentos realizados no experimento.

Com o objetivo de avaliar conjuntamente os dois fatores tipo de cozimento e temperatura com relação à Capacidade de Retenção de Água foi adotado o seguinte modelo fatorial : $Y_{i j}=\mu+X_{2 i}+X_{3 j}+\left(X_{2}{ }^{*} X_{3}\right)_{i j}+E_{i j}$ onde: $Y$ é a variável dependente capacidade de retenção de água, $\mathrm{X} 2_{\mathrm{i}}$ corresponde aos níveis tipos de cozimento $(\mathrm{i}=2), \mathrm{X}_{3 \mathrm{j}}$ corresponde aos níveis de temperatura $(\mathrm{j}=2)$ e $\mathrm{X}_{2 \mathrm{ij}}{ }^{{ }^{*}} \mathrm{X}_{3 \mathrm{ij}}$ corresponde a interação entre eles (Tabela 7).

Os resultados foram analisados considerando um nível de confiança de $95 \%$ e demonstraram que houve uma diferença significativa entre os meios de cozimento água e vapor para a variável CRA (Tabela 7). 
Tabela 7. Efeitos da variação dos tratamentos na capacidade de retenção de água das amostras

\begin{tabular}{cccccc}
\hline Fonte & $\begin{array}{c}\text { Soma de } \\
\text { Quadrados }\end{array}$ & Df & $\begin{array}{c}\text { Quadrado } \\
\text { Médio }\end{array}$ & $\mathrm{F}$ & Sig. \\
\hline Modelo & $0,231^{\mathrm{a}}$ & 3 & $7,700 \mathrm{E}-02$ & 262,706 & 0,000 \\
Corrigido & & & & & \\
Interceptação & 9,761 & 1 & 9,761 & 33301,098 & 0,000 \\
X2 & $5,400 \mathrm{E}-02$ & 1 & $5,400 \mathrm{E}-02$ & 184,235 & 0,000 \\
X3 & 0,150 & 1 & 0,150 & 511,765 & 0,000 \\
X2 ${ }^{*}$ X3 & $0,000 \mathrm{E}-03$ & 1 & $0,000 \mathrm{E}-02$ & 20,471 & 0,000 \\
Erro & $3,400 \mathrm{E}-02$ & 100 & $2,931 \mathrm{E}-04$ & & \\
Total & 12,172 & 120 & & & \\
Total Corrigido & 0,265 & 119 & & & \\
\hline
\end{tabular}

${ }^{\mathrm{a}} \mathrm{R}$ quadrado $=0,872(\mathrm{R}$ quadrado ajustado $=0,868)$

Pode-se observar que com relação a variável tipo de cozimento (x2) que existe diferença significativa entre estufa e tacho para variável CRA. O mesmo acontece com a variável temperatura (x3), quer dizer que também existe diferença significativa entre os níveis de tratamento em relação a variável CRA. Também a interação entre as variáveis tipo de cozimento e temperatura é significativa.

A utilização da temperatura de $80^{\circ} \mathrm{C}$ provocou um aumento significativo na capacidade de retenção de água das amostras.

Este resultado é teoricamente discordante com Hostetler e Landman (1968). Segundo estes autores, o aumento na taxa de cozimento provoca uma maior desnaturação das proteínas miofibrilares, diminuindo a capacidade de 
retenção de água na carne. Os referidos autores atribuem o fenômeno a saída de líquido pelos espaços interfibrilares.

A interação entre os tratamentos em nível de $95 \%$ foi significativa. $O$ tratamento utilizando-se água a $70^{\circ} \mathrm{C}$ foi o que apresentou menor índice de capacidade de retenção de água. Sob o ponto de vista de rendimento, entre outros atributos, este tratamento no que diz respeito à CRA poderia então ser considerado o menos adequado.

Os resultados encontrados são discordantes da literatura sobre capacidade de retenção de água. Existem várias metodologias utilizadas para avaliar a capacidade de retenção de água, provavelmente em função da metodologia escolhida. Lawrie (1988) cita que a técnica de centrifugação é a mais indicada para produtos cárneos cozidos, uma vez que possibilita uma maior "contabilização" das quantidades de líquido presentes na amostra pois esta técnica pode incluir melhor a gordura existente. Provavelmente esta técnica traria resultados condizentes com a literatura de referência sobre o tema. 
Tabela 8. Capacidade de retenção de água das amostras cozidas em água e vapor a temperaturas de $70^{\circ} \mathrm{C}$ e $80^{\circ} \mathrm{C}^{*}$

\begin{tabular}{cccc}
\hline Tipo de cozimento & $\begin{array}{c}\text { Temperatura de } \\
\text { Cozimento }\end{array}$ & CRA (média) & Erro Padrão \\
\hline Água & $70^{\circ} \mathrm{C}$ & 0,25 & 0,007 \\
Vapor & $70^{\circ} \mathrm{C}$ & 0,28 & 0,005 \\
Água & $80^{\circ} \mathrm{C}$ & 0,31 & 0,002 \\
Vapor & $80^{\circ} \mathrm{C}$ & 0,37 & 0,002 \\
\hline
\end{tabular}

*Total de 6 (seis) amostras em cada processamento

\subsection{Avaliação das perdas por cocção}

A Tabela 9 mostra a influência da temperatura de cozimento nas perdas por cozimento e na maciez encontrada em cada um dos tratamentos.

Com o objetivo de avaliar se houve interação entre os tratamentos (tipo de cozimento e temperatura), no que diz respeito à variável perda por cozimento, foi estimado o seguinte modelo fatorial $Y_{i j}=\mu+X_{2 i}+X_{3 j}+\left(X_{2}{ }^{*} X_{3}\right)_{i j}+$ $E_{i j}$ onde: $Y$ é a variável dependente perdas por cozimento, $X_{2 i}$ corresponde aos níveis tipos de cozimento ( $\mathrm{i}=2), \mathrm{X}_{3 \mathrm{j}}$ corresponde aos níveis de temperatura $(j=2)$ e $X_{2 i}{ }^{*} X_{3 i j}$ corresponde a interação entre eles (Tabela 9). 
Tabela 9. Efeitos da variação dos tratamentos nas perdas por cozimento das amostras

\begin{tabular}{cccccc}
\hline Fonte & $\begin{array}{c}\text { Soma de } \\
\text { Quadrados Tipo } \\
\text { III }\end{array}$ & Df & $\begin{array}{c}\text { Quadrado } \\
\text { Médio }\end{array}$ & F & Sig. \\
\hline Modelo & $2442,241^{\text {a }}$ & 3 & 814,080 & 79,380 & 0,000 \\
Corrigido & & & & & \\
Interceptação & 109978,891 & 1 & 109978,891 & 10723,880 & 0,000 \\
X2 & 732,203 & 1 & 732,203 & 71,396 & 0,000 \\
X3 & 1704,534 & 1 & 1704,534 & 166,207 & 0,000 \\
X2 * X3 & 126,150 & 1 & 126,150 & 12,301 & 0,001 \\
Erro & 1189,639 & 116 & 10,256 & & \\
Total & 137839,977 & 120 & & & \\
Total & 3631,880 & 119 & & & \\
Corrigido & & & & & \\
\hline
\end{tabular}

${ }^{\mathrm{a}} \mathrm{R}$ quadrado $=0,672(\mathrm{R}$ quadrado ajustado $=0,664)$

Observa-se que existe diferença significativa $(P<0,05)$ entre os tipos de cozimento em relação a variável perda por cozimento. O mesmo acontece com a variável temperatura de cozimento isto é existe diferença significativa entre os dois tipos de temperatura em relação a variável perda por cozimento.

A maior perda por cozimento ocorreu nos tratamentos utilizando-se temperatura de $80^{\circ} \mathrm{C}$, tanto na água quanto no vapor. $\mathrm{O}$ vapor provocou uma perda por cozimento maior em ambas temperaturas.

Girard (1991) cita que o calor úmido provoca maior perda que o calor seco, sendo a diferença conseqüência de uma possível capa que se forma em torno da peça de carne cozida. Aqui cabe destacar que a embalagem utilizada nas peças foram idênticas, sem contato com o meio externo, com o objetivo de anular esta possível variável. 
A maior perda por cozimento em experimentos utilizando diferentes temperaturas é um resultado comumente encontrado em vários trabalhos que avaliam as perdas decorrentes pela cozimento.

Estudos com objetivo de correlacionar tempo de cozimento e perdas por cozimento observam que o aumento do tempo de cozimento incrementa as perdas por cozimento.

Os resultados obtidos neste experimento concordam com aqueles encontrados por Ritchey e Hostetler (1965) que ao aquecerem amostras de carne em várias temperaturas $\left(61^{\circ} \mathrm{C}, 68^{\circ} \mathrm{C}, 74^{\circ} \mathrm{C}\right.$ e $\left.80^{\circ} \mathrm{C}\right)$, encontraram uma correlação positiva entre o atributo perdas por cozimento e aumento de temperatura. Wheeler et al. (1998) ao avaliar os atributos maciez objetiva, perdas por cozimento, e avaliação sensorial em dois métodos de cozimento (grelhado e assado), também encontrou diferenças no que diz respeito à maciez objetiva. Porém o autor considerou esta diferença pequena, podendo não ter importância na prática.

Em experimento realizado por Palka e Daun (1999) com bifes de Semitendinosus, foi encontrado incremento na perda de fluidos durante o cozimento na faixa de temperatura de $50^{\circ} \mathrm{C}-60^{\circ} \mathrm{C}$ e entre $70^{\circ} \mathrm{C}-80^{\circ} \mathrm{C}$, de 10,3 e 9,7\%, respectivamente. Os autores explicam a perda de fluidos, em razão de duas alterações básicas na estrutura protéica da carne: complexo actomiosina e no colágeno. Califano et al. (1997), afirmaram que ao se aquecer um produto cárneo utilizando temperaturas entre $40^{\circ} \mathrm{C}$ e $60^{\circ} \mathrm{C}$, ocorre uma desnaturação muito grande na actina e que esta desnaturação é responsável pela perda de fluidos ocorrida no produto. 
Tabela 10. Perdas por cozimento e maciez objetiva encontradas em cada tratamento

\begin{tabular}{cccccc}
\hline $\begin{array}{c}\text { Tipo de } \\
\text { Cozimento }\end{array}$ & $\begin{array}{c}\text { Temperatura de } \\
\text { Cozimento }\left({ }^{\circ} \mathrm{C}\right)\end{array}$ & $\begin{array}{c}\text { Perda por } \\
\text { Cozimento } \\
(\%)\end{array}$ & $\begin{array}{c}\text { Erro } \\
\text { Padrão }\end{array}$ & $\begin{array}{c}\text { Maciez } \\
\text { Objetiva } \\
\left(\mathrm{Kgfl}^{2}\right)\end{array}$ & $\begin{array}{c}\text { Erro } \\
\text { Padrão }\end{array}$ \\
\hline Água & $70^{\circ} \mathrm{C}$ & 31,8 & 0,16 & 6,17 & 0,28 \\
Vapor & $70^{\circ} \mathrm{C}$ & 24,4 & 1,27 & 6,45 & 0,28 \\
Água & $80^{\circ} \mathrm{C}$ & 37,64 & 0,28 & 5,83 & 0,37 \\
Vapor & $80^{\circ} \mathrm{C}$ & 34,57 & 0,52 & 6,5 & 0,42 \\
\hline
\end{tabular}

* Total de 6 (seis) amostras

\subsection{Maciez objetiva}

Na Tabela 10 são apresentados os resultados relativos aos índices de maciez encontrados no presente trabalho. O índice de maciez mais baixo encontrado no presente trabalho foi de 5,83. Experimento realizado Shacckeford et al. (1995), analisou a relação existente entre a maciez objetiva medida pelo Warner Bratzler Shear Force e um grupo de provadores em 10 cortes de carne bovina cozidas. As amostras de Semitendinosus foram assadas, e o índice para WBSF encontrado foi de $4,1 \mathrm{Kgf} / \mathrm{cm}^{2}$, uma maciez considerada intermediária pelo autor. A diferença entre os resultados encontrados no presente trabalho e o realizado por Shacckeford pode ser devido ao método de cozimento, assim como o tempo de maturação (14 dias) utilizado no experimento citado, já que este experimento não utilizou cortes maturados. 
A Tabela 11 apresenta os efeitos da variação dos tratamentos na maciez das amostras. Observa-se que não foi encontrada diferença significativa $(P \geq 0,05)$ entre os meios de cozimento utilizados.

Tabela 11. Efeitos da variação dos tratamentos na maciez das amostras

\begin{tabular}{cccccc}
\hline Fonte & $\begin{array}{c}\text { Soma de } \\
\text { Quadrados }\end{array}$ & df & $\begin{array}{c}\text { Quadrado } \\
\text { Médio }\end{array}$ & $F$ & Sig. \\
\hline Modelo Corrigido & $12,423^{\mathrm{a}}$ & 3 & 4,141 & 0,848 & 0,471 \\
Interceptação & 4183,350 & 1 & 4183,350 & 856,385 & 0,000 \\
X2 & 7,073 & 1 & 7,073 & 1,448 & 0,231 \\
X3 & 0,267 & 1 & 0,267 & 0,055 & 0,816 \\
X2 ${ }^{*}$ X3 & 1,536 & 1 & 1,536 & 0,314 & 0,576 \\
Erro & 566,648 & 116 & 4,885 & & \\
Total & 5260,323 & 120 & & & \\
Total Corrigido & 579,071 & 119 & & & \\
\hline
\end{tabular}

${ }^{a} R$ quadrado $=0,021(R$ quadrado ajustado $=-0,004)$

Segundo Price (1994), a seleção do método de cozimento a ser utilizado pode afetar os atributos maciez, suculência e sabor, assim como as suas propriedades mecânicas. Lawrence et al. (2001), avaliou três métodos diferentes de cozimento e não encontrou diferença consistente entre os tratamentos utilizados, assim como o presente trabalho. $O$ autor afirma que os fatores pré-abate e a relação tempo-temperatura continuam sendo os mais influentes na maciez das amostras.

Califano et al. (1997), ao estudarem os efeitos do tempo e da temperatura nos padrões de textura do músculo Semitendinosus aquecido entre $50^{\circ} \mathrm{C}$ e $90^{\circ} \mathrm{C}$, encontraram um decréscimo no endurecimento entre $58^{\circ} \mathrm{C}$ e $60^{\circ} \mathrm{C}$ atribuído à reação do colágeno, resultando numa carne mais macia nesta faixa 
de temperatura. Os autores citam que à medida que houve um incremento na temperatura para $65^{\circ} \mathrm{C}$ e $75^{\circ} \mathrm{C}$, a carne tornou-se mais dura. Discordando com os resultados obtidos por Califano (1997), a utilização da temperatura de $70^{\circ} \mathrm{C}$ no presente experimento resultou numa amostra com textura considerada boa sob o ponto de vista da maciez objetiva. O impedimento neste trabalho com relação a esta temperatura foi o número de reduções decimais alcançadas que não foram compatíveis com o processo de pasteurização.

$\mathrm{O}$ cozimento com o objetivo de atingir uma temperatura final de $65^{\circ} \mathrm{C}$ no interior das amostras em três fases de cozimento foi utilizado por Powell (2000) em músculos Semitendinosus com o objetivo de avaliar a maciez e presença de colágeno nas amostras. O autor utilizou amostras maturadas, embaladas a vácuo, cortadas em fatias e com tempo de cozimento de 3,5 horas em fornos com circulação forçada de ar. Os resultados encontrados pelo autor foram 4,7 Kgf/ $/ \mathrm{cm}^{2}$ utilizando o cozimento em um único estágio e $3,3 \mathrm{Kgf} / \mathrm{cm}^{2}$ utilizando o cozimento em três estágios, o que demonstra uma maior eficácia do segundo tratamento na obtenção de amostras com melhor índice de maciez. A maciez citada por estes autores é maior considerando uma força de cisalhamento menor que aquela encontrada no presente trabalho. A diferença entre o tempo utilizado por Powell (2000) e o presente experimento é de 2 horas, o que leva a uma acentuada diferença de tempo de processamento. Isto provavelmente indique que um maior tempo de cozimento pode ser mais aconselhável sob o ponto de vista da maciez, devendo-se apenas atentar para a viabilidade prática deste procedimento.

Outros trabalhos (Laakkonen et al., 1970; Lawor et al., 2000, Ritchey \& Hostetler, 1965), utilizaram tempos muito maiores enquanto as temperaturas foram sempre próximas de $60^{\circ} \mathrm{C}$, com isso, foram obtidos produtos com textura menor que as encontradas neste trabalho. As baixas temperaturas utilizadas por longo tempo provavelmente foram as responsáveis pelos resultados encontrados pelos autores. 


\subsection{Análise sensorial}

A avaliação sensorial foi realizada verificando os atributos maciez, suculência, colágeno e sabor nos meios de cozimento água e vapor, na temperatura de $80^{\circ} \mathrm{C}$. Os resultados encontram-se na Tabela 12.

Observa-se que não foi encontrada diferença significativa entre os tratamentos utilizando água e vapor em nenhum dos atributos sensoriais avaliados.

Otremba et al. (1999), avaliaram sensorialmente o músculo Semitendinosus utilizando temperatura de $71^{\circ} \mathrm{C}$ num painel descritivo utilizando entre 8 e 10 provadores treinados, utilizando-se escala estruturada de 15 pontos com intervalos de 0,5 sendo 0 correspondente a menor intensidade e 0 15 correspondente à intensidade máxima. As médias encontradas pelo autor foram 5,1 para suculência, 5,5 para presença de colágeno, 5,2 para sabor e 5,6 para maciez. Os dados relativos à maciez e sabor demonstram um produto menos macio que os encontrados no presente trabalho. Já a presença de colágeno e a suculência mostram-se maiores no presente trabalho.

Laakonen (1990), avaliando o cozimento de cortes de Semitendinosus, Rectus femoris e Longissimus dorsi, por períodos de até 24 h, verificou que o encolhimento do colágeno se relaciona com a temperatura utilizada, podendo ter como resultado influência na maciez objetiva. Segundo ele, os melhores resultados foram obtidos com cozimentos utilizando baixas temperaturas por longos períodos. 
Tabela 12. Notas resultantes da avaliação sensorial

\begin{tabular}{ccccc}
\hline Tratamento & Maciez & Suculência & Colágeno & Sabor \\
\hline Água $80^{\circ} \mathrm{C}$ & $5,91^{\mathrm{a}}$ & $4,63^{\mathrm{b}}$ & $1,75^{\mathrm{c}}$ & $5,05^{\mathrm{d}}$ \\
Vapor $80^{\circ} \mathrm{C}$ & $5,47^{\mathrm{a}}$ & $4,51^{\mathrm{b}}$ & $2,63^{\mathrm{c}}$ & $5,41^{\mathrm{d}}$ \\
\hline
\end{tabular}

Nota: os resultados correspondem a avaliação realizada utilizando-se uma escala não estruturada de 0 a 10 onde o 0 corresponde aos menores índices e o 10 corresponde aos maiores índices na percepção dos provadores para cada atributo sensorial avaliado

A variável maciez foi escolhida como variável a ser fixada devido a sua grande influência nos atributos de qualidade da carne em geral.

Objetivando saber a relação existente entre os atributos acima, inicialmente foi realizada a análise de correlação de Pearson. No meio de cozimento água, o resultado encontrado é que existe uma correlação significativa em nível de $99 \%$ de confiança entre os quesitos maciez e suculência.

Tabela 13. Correlação entre os atributos cozimento em água

\begin{tabular}{lcccc}
\hline & Maciez & Suculência & Colágeno & Sabor \\
\hline Maciez & 1 & $0,481^{* *}$ & $-0,182$ & 0,058 \\
Suculência & $0,481^{* *}$ & 1 & $-0,125$ & 0,088 \\
Colágeno & $-0,182$ & $-0,125$ & 1 & 0,027 \\
Sabor & 0,058 & 0,088 & 0,027 & 1 \\
\hline
\end{tabular}

** Correlação em nível de $1 \%$ 
Para verificar em que medida os atributos presença de colágeno, sabor e suculência influenciariam na maciez, foi elaborado um modelo de regressão linear múltipla para saber quais variáveis têm influência positiva ou negativa na maciez das amostras. $O$ modelo empregado foi: $Y_{1}=\beta_{0}+\beta_{1} X_{i 1}+\beta$ ${ }_{2} X_{i 2}+\beta_{3} X_{i 3}+E_{i}$, onde $Y_{i}$ é maciez, $X_{i 1}$ é suculência, $X_{i 2}$ colágeno, $X_{i 3}$ sabor e $E_{i}$ é o erro associado ao produto.

$O$ modelo estimado foi: $Y_{1}=0.657 X_{i_{1}}+0.136 X_{i_{2}}+0.0191 X_{i_{3}}+$ 2.721 .

Neste caso, a única variável que foi significativa para o modelo foi a suculência $(P<0.01)$, isto é, pequenas mudanças na suculência vão influenciar positivamente na maciez em nível de $99 \%$ de confiança. Em relação ao modelo estimado todas as suposições foram satisfeitas.

Segundo Felício (2004), o problema associado aos testes de Análise Descritiva Quantitativa e a todas as pesquisas que dele se utilizam, reside principalmente na questão da palatabilidade. $O$ autor cita que inevitavelmente os provadores são influenciados pelos hábitos e temporais de consumo alimentar. Assim, por exemplo, segundo ele a carne de sabor brando de gado jovem de confinamento que tanto agrada ao paladar dos norte-americanos, pode parecer insípida ao gosto dos brasileiros, uma vez que estes estão acostumados a uma carne de sabor intenso. Para o atributo maciez, quando os provadores são treinados, Felício (2004), considera que em geral as conclusões podem ser extrapoladas de uma situação a outra porque a seleção e o treinamento é feito de modo a que o provador funcione quase como um instrumento de medida. Assim, os atributos poderiam ser de certa forma associados de maneira errônea pelos provadores.

Neste trabalho, os atributos presença de colágeno e sabor não exerceram influência significativa na maciez.

A relação entre tecido conjuntivo e miofibrila não foi avaliada quantitativamente e como são as responsáveis pelos efeitos opostos na maciez 
da carne quando por ocasião do cozimento alguns resultados relativos a este atributo não puderam ser explicados.

As temperaturas com variações muito maiores, entre $60^{\circ} \mathrm{C}$ e $90^{\circ} \mathrm{C}$ tal como as utilizadas Califano et al. (1997) provavelmente permitiriam uma maior variação nas texturas medidas e maior percepção das diferenças sensoriais no atributo maciez sensorial.

Este resultado concorda com aqueles encontrados por Otremba et al. (2000), que concluíram que o sabor não apresentou correlação com nenhum outro atributo avaliado (suculência, firmeza, fibrosidade, maciez, facilidade em mastigar) em cortes cozidos de músculos Semitendinousus.

Observando-se os resultados onde o vapor foi utilizado como meio de cozimento, verificou-se que existe uma correlação significativa em nível de $1 \%$ $(P<0.01)$, entre os quesitos maciez e suculência e uma correlação negativa entre os atributos presença de colágeno e maciez.

Segundo Dinardo (1984), as mudanças na textura em cortes com alto teor de tecido conjuntivo, não são explicadas pelo conteúdo de colágeno medido nos cortes estudados, e sim na solubilidade do mesmo decorrente do tempo de cozimento das amostras. O maior tempo de cozimento seria a explicação deste autor para a carne mais macia, devido à fração inalterada de colágeno que é dependente da conjugação de tempo-temperatura de cozimento. 
Tabela 14. Correlação entre os atributos cozimento em vapor

\begin{tabular}{ccccc}
\hline & Maciez & Suculência & Colágeno & Sabor \\
\hline Maciez & 1 & $0.518^{* *}$ & $-0.299^{* *}$ & 0.029 \\
Suculência & $0.518^{* *}$ & 1 & -0.091 & -0.014 \\
Colágeno & $-0.299^{* *}$ & -0.091 & 1 & 0.051 \\
Sabor & 0.029 & -0.014 & 0.051 & 1 \\
\hline
\end{tabular}

${ }^{* *}$ Existe significância em nível de 1\%

Para verificar em que medida os atributos presença de colágeno, sabor e suculência poderiam influenciar na maciez, foi elaborado um modelo de regressão linear múltipla para saber quais as variáveis influenciaram na maciez positiva ou negativamente. $O$ modelo empregado foi: $Y_{1}=\beta_{0}+\beta_{1} X_{i 1}+\beta_{2} X_{i 2}+$ $\beta_{3} X_{i 3}+E_{i}$, onde $Y_{i}$ é maciez, $X_{i 1}$ é suculência, $X_{i 2}$ colágeno, $X_{i 3}$ sabor e $E_{i}$ é o erro associado ao produto

O modelo estimado foi: $Y_{1}=0.683 X_{i_{1}}+0.204 X_{i_{2}}+0.0507 X_{i_{3}}+$ 2.470 .

Os dados das freqüências de maciez quando distribuídos no histograma apresentaram a forma de curva normal com padrão elíptico de distribuição (Figuras 4 e 5), demonstrando assim que os valores encontrados evidenciam uma distribuição normal conforme o esperado. 


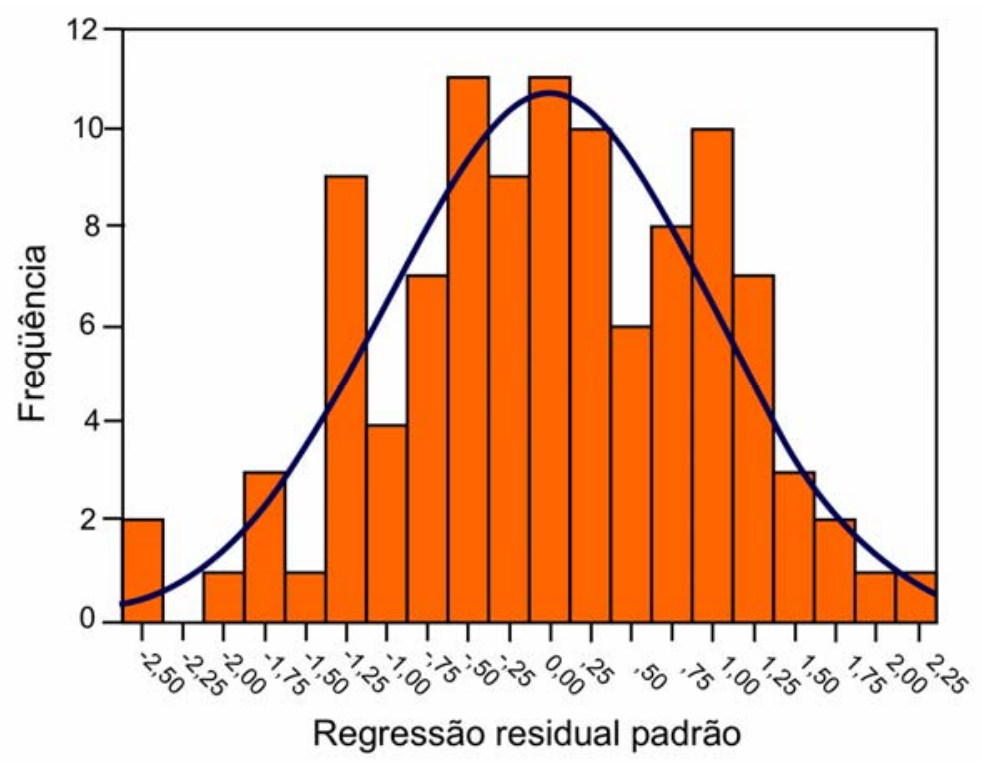

Figura 4 - Histograma representando a curva de distribuição normal. Variável maciez (tratamento água)

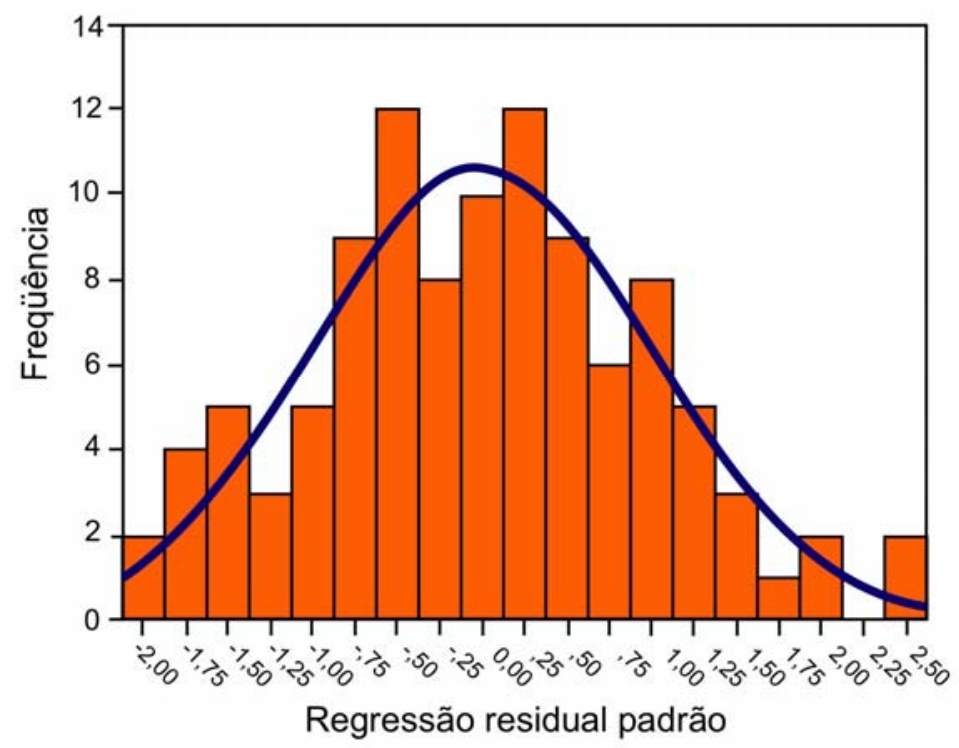

Figura 5 - Histograma representando a curva de distribuição normal. Variável maciez (tratamento vapor)

Neste caso, verificou-se que a suculência exerceu influência positiva em nível de $1 \%(P<0.01)$, sobre a maciez, isto é, pequenos aumentos na 
suculência são capazes de aumentar a maciez da amostra. O colágeno apresentou uma correlação negativa em nível de $1 \%$ sobre a maciez, isto é, um pequeno aumento na quantidade de colágeno, diminuiu significativamente a maciez da amostra.

Concordando com os resultados encontrados no presente trabalho, Seidman et al. (1984), diz que o colágeno é o fator de qualidade primariamente responsável pelos problemas com a maciez da carne, sendo que o aumento deste constituinte responsável pelo aumento da dureza da mesma.

Christensen (1999) avaliou o músculo Semitendinosus cozido inteiro objetivando verificar o comportamento do tecido colagênico e das miofibrilas correlacionando o estudo da fibra com as avaliações de força de cisalhamento. Concordando com os resultados encontrados no presente trabalho, o autor afirmou que a fibra colagênica é um importante fator de influência na avaliação da maciez encontrada na carne.

Laakonen (1990), avaliando o cozimento de cortes de Semitendinosus, Rectus femoris e Longissimus dorsi, por períodos de até $24 \mathrm{~h}$, verificou que o encolhimento do colágeno se relaciona com a temperatura utilizada, podendo ter como resultado influência na maciez objetiva. Segundo ele, os melhores resultados foram obtidos com cozimento $s$ utilizando baixas temperaturas por longos períodos. 


\section{CONCLUSÕES}

Não houve diferença significativa no atributo maciez objetiva encontrado nos dois tratamentos utilizados.

A suculência apresentou uma correlação positiva com a maciez indicando que pequenos aumentos de intensidade na suculência aumentam igualmente a maciez das amostras, enquanto que, o colágeno apresentou uma correlação negativa com a maciez indicando que pequenas diminuições na quantidade de colágeno diminuíram igualmente a maciez das amostras.

A força de cisalhamento não foi afetada pelo tipo de cozimento, pela temperatura e nem pela perda de fluídos.

À temperatura de $80^{\circ} \mathrm{C}$ utilizando-se o vapor como meio de cozimento, a menor redução decimal alcançada foi de 10,34 ciclos logarítmicos, o que caracteriza um processamento adequado para o Semitendinosus sob o ponto de vista microbiológico.

A temperatura de $70^{\circ} \mathrm{C}$ não foi suficiente para a pasteurização neste experimento.

Foi encontrada uma correlação positiva entre a temperatura e a CRA.

Foi encontrada uma diferença significativa entre os tratamentos utilizando-se água e vapor no que diz respeito à CRA. 


\section{REFERÊNCIAS BIBLIOGRÁFICAS}

AMERICAN MEAT SCIENCE ASSOCIATION AND NATIONAL LIVE STOCK AND MEAT BOARD (AMSA). Research guidelines for cookery, sensory evaluation and instrumental tenderness measurements of fresh meat. Chicago, 1995. cap.1, p.7-33.

ASSOCIATION OF OFFICIAL ANALYTICAL CHEMISTS (AOAC). Official methods of analysis. 13.ed. Washington, 1990. 2v.

BELCHIOR, F. Ingredientes para pratos prontos: mais uma alternativa de consumo. Revista Nacional da Carne, n.323, p.68-78, 2004.

BOURNE, M.C. Texture profile analysis. Food Technology, v.32, n.7, p.62-66, 1978.

BAILEY, A.J.; LIGHT, N.D. Meat and meat products. Bristol: Elsevier Applied Science, 1989. 355p.

BOUTON, P.E.; HARRIS, P.V. A comparison of some objective methods used to assess meat tenderness. Journal of Food Science, v.37, n.1, p.218-221, 1972. 
BRASIL. Agência Nacional de Vigilância Sanitária (ANVISA). Resolução (RDC) $n^{\circ}$ 12: regulamento técnico sobre padrões microbiológicos para alimentos de 02 de janeiro de 2001, http://www.anvisa.gov.br/legis/resol/12_rdc.htm (10 dez. 2003)

BRENNAN, J.G.; BTTERS, J.R.; COWELL, N.D.; LILLY A.E.V. Las operaciones de la ingeneria de los alimentos. Zaragoza: Editorial Acribia, 1980a. cap.11, p.257: Tratamento térmico.

BRENNAN, J.G.; BTTERS, J.R.; COWELL, N.D.; LILLY A.E.V. Las operaciones de la ingeneria de los alimentos. Zaragoza: Editorial Acribia, 1980b. cap.20, p.518-524: Formulas para la transmission del calor.

CALIFANO, A.N.; BERTOLA, N.C.; BEVILAQUA, A.E.; ZARITZKY, N.E. Effect of processing conditions on the hardness of cooked beef. Journal of Food Engineering, v.34, n.1, p.41-54, 1997.

CHRISTENSEN, M.; PURSLOW, P.P.; LARSEN, L.M. The effect of cooking temperature on mechanical properties of whole meat, single muscle fibres and perimysial connective tissue. Meat Science, v.55, n.1, p.301-307, 2000.

DAMÁSIO, M.H. Curso de análise sensorial de alimentos. Campinas: Fundação Tropical de Pesquisas de Alimentos e Tecnologia André Toselo, 1991a. cap.1, p.28-49: Ambiente.

DAMÁSIO, M.H. Curso de análise sensorial de alimentos. Campinas: Fundação Tropical de Pesquisas de Alimentos e Tecnologia André Toselo, 1991b. cap.2, p.65-69: ADQ. 
DAMÁSIO, M.H. Curso de análise sensorial de alimentos. Campinas: Fundação Tropical de Pesquisas de Alimentos e Tecnologia André Toselo, 1991c. cap.3, p.79-84: Seleção de provadores.

DAVEY, C.L.; GILBERT, K.V. Temperature dependent cooking toughness in beef. Journal of Science Food and Agriculture, v.25, n.3, p.931-938, 1974.

DINARDO, M.; BUCK, E.M.; CLYDESDALE, F.M. Effect of extented cook times on certain physical and chemical characteristics of beef prepared in a watherbath. Journal of Food Science, v.49, n.3, p.844-848, 1984.

EMPRESA BRASILEIRA DE PESQUISA AGROPECUÁRIA (EMBRAPA). Padronização dos cortes de carne bovina. http://www.cnpgc.gov.br/publicações/nãoseriadas/textos/lagarto.html ago. 2004)

FAUFTMAM, C.P.; CASSENS, R.G. Basis for fresh meat discoloration. Journal of Muscle Food, v.1, n.3, p.217-243, 1990.

FELICIO, P.E. Qualidade da carne bovina: características físicas e organolépticas http://www.sbz.org.br/eventos/PortoAlegre/homepagesbz /Pedro_felicio.htm (10 jan. 2004)

FERREIRA, V.L.P.; ALMEIDA, T.C.A.; SILVA, M.A.A.P. da; CHAVES, J.B.P. et al. (Eds.). Análise sensorial: testes discriminativos e afetivos. Campinas: SBCTA, 2000. cap.6, p.54-71: Testes afetivos.

FRANCO, G. Tabela de composição dos alimentos. Rio de Janeiro: Livraria Atheneu Editora, 2001. 307p. 
GAVA, A.J. Princípios de tecnologia de alimentos. São Paulo: Nobel, 1978. cap.2, p.57-74: Microbiologia de alimentos.

GIRARD, J.P. Tecnologia de la carne e de los productos carnicos. Zaragoza: Editorial Acribia, 1991. cap.2, p.35-53: El tratamento culinario.

GONÇALVES, J.R.; GERMER, S.P.M. (Coord.). Princípios de esterilização de alimentos. Campinas: ITAL, Rede de Núcleos de Informação Tecnológica, 1992. 116p. (ITAL. Manual Técnico, 10)

GRAU, R.; HAMM, R. Erne einfache method bestimmung der waserbinding in muskel. Naturwessenchaft, v.40, n.1, p.29-33, 1953.

HAMM, R. Properties of meat proteins. In: LAWRIE, R.A. (Ed.). Proteins as human food. Wesport: AVI Publishing Co, 1969. cap.5, p.167-185.

HAMM, R.; HONIKEL, K.O.; FISCHER; C. HAMID, A. Modificaciones en la carne vacuna luego de la faena y sus consecuencias sobre la capacidade de retención de agua. Fleischwirtchaft, v.1, n.1, p.42-48, 1983.

HARRIS, P.V.; SHORTOSE, W.R. Meat texture. In: LAWRIE, R. (Ed.). Developments in meat science-4. London: Elsevier Applied Science, 1988. cap.5, p.245-298.

HART, R.J. The canning of fish and meat. In: FOOTITT, R.J.; LEWIS, A.S. (Ed.). Microbiology of meat raw materials. London: Blackie Academic and Professional, 1995. cap.3, p.57-58. 
HAY, P.P.; HARRISON, D.L.; VAIL, G.E. Effects of a meat tenderizer on less tender cuts of beef cooked by four methods. Food Technology, v.7, n.5, p.217-220, 1953.

HERSHBERGER, T.; DEANS, R.; KUNKLE, L.E.; GERLAUGH, P.; DEATHERAGE, F.E. Studies on meat III. The biochemistry and quality of meat in relation to certain feeding management pratices. Food Technology, v.16, n.12, p.523-527, 1951.

HOFFMANN, H.; HAMM, R.; BLUCHEL, E. Neus über die bestimung der wasserbinding des nut hielf filter paper premethods. Fleishwirtchaft, v.62, n.1, p.87-94, 1982.

HONIKEL, K.O.; HAMM, R. Measurement of water holding capacity and juiciness. In: PEASON, A.M.; DUTSON, T.R. (Ed.). Quality attributes and their measurement in meat, poultry and fish products. London: Blackie Academic and Professional, 1994. cap.5, p.125-161.

HOSTETLER, R.L.; LANDMAN, W.A. Photomicrographic studies of dynamic changes in muscles fiber fragments. 1. Effect of various heat treatments on length width and birefringence. Journal of Food Science, v.33, n.1, p.468470, 1968.

INTERNATIONAL COMMISSION ON MICROBIOLOGICAL SPECIFICATIONS FOR FOODS (ICMSF). El sistema de análises de riesgos e puntos críticos: su aplicacion a las industrias de alimentos. Zaragoza: Editorial Acribia, 1988. 332p. 
INTERNATIONAL COMMISSION ON MICROBIOLOGICAL SPECIFICATIONS FOR FOODS (ICMSF). Microbial ecology of foods. London: Academic Press, 1980. 997p.

JAY, J.M. Modern food microbiology. New York: Chapman and Hall, 1996. cap.17, p.348-356: Indicators of food microbial quality and safety.

JUDGE, M.P.; ALBERLE, E.D.; FORREST, J.C.; HEDRICK H.B.; MERKEL R.A. Principles of meat science. Dubuque: Kendall / Hunt Publishing,1989a. cap.1, p.11-23: Muscle and associated tissues.

JUDGE, M.P.; ALBERLE, E.D.; FORREST, J.C.; HEDRICK H.B.; MERKEL R.A. Principles of meat science. Dubuque: Kendall / Hunt Publishing,1989b. cap.8, p.175: Microbiology, deterioration and contamination of meat.

JUNQUEIRA, V.C.A. Avaliação da incidência de Clostridium botulinum e da produção de toxina em mortadela e presunto. Campinas, 1994. 57p. Dissertação (Mestrado) - Faculdade de Engenharia de Alimentos, Universidade de Campinas.

KNIGHT, P.; OFFER, G. The structural basis of water-holding in meat. Part 1: General principles and water holding uptake in meat processing. In: LAWRIE, R. (Ed.). Developments in meat science-4. London: Elsevier Applied Science, 1988. cap.3, p.172-239.

LAKKONEN, E.; WELLINGTON, G.H.; SHERBON, J.W. Low temperature, long time heating of bovine muscle. Journal of Food Science, v.35, n.1, p.175177, 1970. 
LAWRIE, R.A. Ciência de la carne. Zaragoza: Editorial Acribia, 1998. cap.10, p.250-256: Calidad organoléptica de la carne.

LAWLOR, K.A.; PIERSON, M.D.; HACKNEY, C.R.; CLAUS, J.R.; MARCY, J.E. Non proteolytic Clostridium botulinum toxigenesis in cooked turkey stored under modified atmospheres. Journal of Food Protection, v.63, n.11, p.1511-1516, 2000.

LAWRENCE, T.E.; KING, D.A.; OBUZ, E.; YANCEY, E.J.; DIKEMAN, M.E. Evaluation of eletric belt grill, forced-air convection oven, and eletric broiler cokery methods for beef tenderness research. Meat Science, v.58, n.3, p.239-246, 2001.

MARTENS, H.; STABUBURVIK, E.; MARTENS, M. Texture and colour changes in meat during cooking related to thermal denaturation of muscle proteins. Journal of Food Texture Studies, v.13, n.4, p.291-309, 1982.

MEILGARD, M.; CIVILLE, G.V.; CARR, B.T. Sensory evaluation techniques. Flórida: CRC Press, 1990. cap.10, p.163-179: Selection and training of panel members.

MOTTRAM, D.S. Flavour formation in meat and meat products: A review. Food Chemistry, v.62, n.4, p.415-428, 1998.

NYATI, H. An evaluation of the effect of storage and processing temperatures on the microbiological status of sous vide extended shelf-life products. Food Control, v.11, n.6, p.471-476, 2000.

NURMI, E.; RING, C. Production of hygienically mechanically recovered meat. Fleischwirtschaft International, v.2, n.1, p.21-22, 1999. 
OFFER, G.; KNIGHT, P. The structural basis of water-holding in meat part 2: drip losses. In: LAWRIE, R. (Ed.). Developments in meat science-4. London: Elsevier Applied Science, 1988. cap.4, p.173-244.

OTREMBA, M.M.; DIKEMAN M.E.; MILLIKEN G.A.; STRODA S.L.; CHAMBERS, E.V.; CHAMBERS, D. Interrelationships between descriptive texture profile sensory panel and descriptive attribute sensory panel evaluations of beef Longissimus and Semitendinosus muscle. Meat Science, v.54, n.4, p.325-332, 2000.

PALKA, K.; DAUN, H. Changes in texture, cooking losses, and myofibrilar structure of bovine M. Semitendinosus during heating. Meat Science, v.51, n.3, p.237-243, 1999.

PARDI, M.C.; SANTOS, I.F.S.; SOUZA, E.R.; PARDI, H.S. Ciência, higiene e tecnologia da carne. Goiânia: CEGRAF-UFG, 1995. v.1, cap.2, p.39-52, Fundamentos da ciência da carne.

PELCZAR, M.J.; CHAN, E.C.S.; KRIEG, N.R. Microbiologia. São Paulo: MakronBooks do Brasil, 1997. v.1, cap.11, p.373-391: Microbiologia de alimentos.

PENFIELD, M.P.; MEYER, B.H. Changes in tenderness and collagen of beef Semitendinosus muscle heated at two rates. Journal of Food Science, v.40, n.3, p.150-154, 1975. 
POWELL, T.H.; DIKEMAN, M.E.; HUNT, M.C. Tenderness and collagen of beef Semitendinosus roasts cooked by convetional convective cooking and modeled, multi-stage, convective cooking. Meat Science, v.55, n.4, p.421425, 2000.

PRANDL, O.; FISCHER, A.; SCHMIDHOFER, T.; SINNEL, H.J. Tecnología e higiene de la carne. Zaragoza: Editorial Acribia, 1994a. cap.4, p.187: Microbiología de la carne.

PRANDL, O.; FISCHER, A.; SCHMIDHOFER, T.; SINNEL, H.J. Tecnologia e higiene de la carne. Zaragoza: Editorial Acribia, 1994b. cap.3, p.122: Sacrifico de aves.

PRICE, J.F.; SCHWEIGERT, B.S. Muscle proteins and palatability. Journal of Food Quality, v.6, n.4, p.290-315, 1984.

PRICE, J.F.; SCHWEIGERT, B.S. Ciencia de la carne y de los produtos carnicos. Zaragoza: Editorial Acribia, 1994a. Seção I, cap.2, p.11-55: La estructura del músculo.

PRICE, J.F.; SCHWEIGERT, B.S. Ciencia de la carne y de los produtos carnicos. Zaragoza: Editorial Acribia, 1994b. Seção I, cap.8, p.299-316: Características organolépticas de la carne.

ROSENTHAL, A.J. Food texture: measurement and perception. Gaithersburg: Aspen Publication, 1999. cap.1, p.1-15: Relation between instrumental and sensory measures of food texture. 
RYBKA, S.; KAILASAPATHY, J.B.; PONIMAM, S.; MIKHAIL, S.; GUNASEKERA, C.; LIN, Y.; FERRARIS, J. Storage characteristics of extended shelf-life cook-chill meals. Food Australia, v.5, n.53, p.191-195, 2001.

SARANTOPÓLUS, C.I.G.L.; OLIVEIRA, L.M.; CANAVESI, E. Requisitos para conservação de alimentos. Campinas: Centro de Tecnologia de Embalagem CETEA/ITAL, 2001. cap.16, p.147-169.

SHACKELFORD, S.D.; WHEELER, T.L.; KOOHMARIE, M. Relationship between shear force and trained sensory painel tenderness rating of 10 major muscles from Bos indicus and Bos taurus cattle. Journal of Animal Science, v.73, n.11, p.3333-3340, 1995.

SZCZESNIAK, A.S. Sensory texture profile historical and scientific perspctives. Food Technology, v.52, n.8, p.52-57, 1998.

SEIDMAN, S.C.; DURLAND, P.R. The effect of cookery on muscle proteins and meat palatability: a review. Journal of Food Quality, v.6, n.4, p.291-314, 1984.

SMITH, G.C. Factors affecting the palatability of beef. http://www.colostate.edu/Depts/AnimSci/ran/beef/smith7pdf (08 Dec. 2003)

SPECIAL PROGRAM FOR SOCIAL SCIENCE (SPSS). Guide to data analysis (software). Chicago: SPSS Inc., 1986.

STUMBO, C.R. Thermobacteriology in food processing. London: Blackie Academic Press, 1965. cap.5, p.55-56. Contamination and it's control. 
TACLINDO, C.; MIDURA, T.; NYGAARD, G.S. Examination of prepared food in plastic packages for Clostridium botulinum. Applied Microbiology, v.15, n.2, p.426-430, 1967.

TORTORA, G.J.; FUNKE, B.R.; CASE, C.L. Microbiologia. Porto Alegre: Artmed Editora, 2000. cap.21, p.585-587: Doenças microbianas do sistema nervoso.

TROUT, G.R. Techniques for measuring water bindind capacity in muscle foods: a review of metodology meat science. Meat Science, v.23, n.4, p.235-252, 1988.

TSAI, T.C.; OCKERMAN, H.W. Water binding measurement of meat. Jounal of Food Science, v.46, n.2, p.697-701, 1981.

UNITED STATES DEPARTAMENT OF AGRICULTURE (USDA). National $\begin{array}{llll}\text { databases for standard } & \text { reference }\end{array}$ http://www.nal.usda.gov/fnic/foodcomp/Data/SR17/wtrank (15 Aug. 2004)

VANDERZANT, C.; SPLITTSTOESSER, D.F. Compendium of methods for microbiological examination foods. Washington: American Public Health Association,1992. 1219p.

VARNAM, A.; SHUTERLAND, J.P. Carne e productos cárnicos. Zaragoza: Editorial Acribia, 1998a. cap.1, p.1-40: Introducción.

VARNAM, A.; SHUTERLAND, J.P. Carne e productos cárnicos. Zaragoza: Editorial Acribia, 1998b. cap.5, p.219-270: Carne cocida y productos cárnicos cocidos. 
WHEELER, T.L.; SHACKELFORD, S.D.; KOOHMARIE, M. Cooking palatability traits of beef Longissimus steaks cooked with a belt grill or a open herth eletric broiler. Journal of Animal Science, v.76, n.11, p.2805-2810, 1998.

WIERBICKI, E.; KUNKLE, L.E.; CAHILL, V.R.; DEATHERAGE, F.E. The relation of tenderness to protein alteration during post-mortem aging. Food Technology, v.8, n.7, p.506-511,1954. 
APÊNDICES 
APÊNDICE 1 - Aquecimento da amostra - Processamento 1 - $70{ }^{\circ} \mathrm{C}$ em água

\begin{tabular}{|c|c|c|c|c|c|}
\hline Tempo(min) & $\mathrm{T}^{\circ} \mathrm{C}$ Meio (água) & $\mathrm{T}^{\circ} \mathrm{C}($ amostra $)$ & Tref & $Z$ & TAXA LETAL \\
\hline 0 & 69,3 & 1,3 & 70 & 8,8 & 1,56E-08 \\
\hline 2 & 75,5 & 1,6 & 70 & 8,8 & 1,69E-08 \\
\hline 4 & 77,7 & 1,8 & 70 & 8,8 & 1,78E-08 \\
\hline 6 & 78,8 & 2,8 & 70 & 8,8 & 2,31E-08 \\
\hline 8 & 78,8 & 2,9 & 70 & 8,8 & 2,37E-08 \\
\hline 10 & 78,7 & 3,1 & 70 & 8,8 & $2,5 \mathrm{E}-08$ \\
\hline 12 & 78,3 & 3,6 & 70 & 8,8 & 2,85E-08 \\
\hline 14 & 78,2 & 4,2 & 70 & 8,8 & 3,33E-08 \\
\hline 16 & 78,2 & 5,3 & 70 & 8,8 & 4,44E-08 \\
\hline 18 & 78,2 & 6,1 & 70 & 8,8 & $5,48 \mathrm{E}-08$ \\
\hline 20 & 78,4 & 7,4 & 70 & 8,8 & 7,7E-08 \\
\hline 22 & 78,1 & 9 & 70 & 8,8 & $1,17 \mathrm{E}-07$ \\
\hline 24 & 77,8 & 10,5 & 70 & 8,8 & 1,73E-07 \\
\hline 26 & 77,3 & 12,3 & 70 & 8,8 & $2,77 E-07$ \\
\hline 28 & 77,2 & 14,1 & 70 & 8,8 & 4,44E-07 \\
\hline 30 & 76,7 & 16,1 & 70 & 8,8 & $7,5 \mathrm{E}-07$ \\
\hline 32 & 76,5 & 18,1 & 70 & 8,8 & 1,27E-06 \\
\hline 34 & 76,2 & 19,8 & 70 & 8,8 & 1,97E-06 \\
\hline 36 & 75,8 & 22,5 & 70 & 8,8 & $4 \mathrm{E}-06$ \\
\hline 38 & 75,6 & 24,8 & 70 & 8,8 & 7,31E-06 \\
\hline 40 & 75 & 26,8 & 70 & 8,8 & 1,23E-05 \\
\hline 42 & 76 & 28,2 & 70 & 8,8 & $1,78 \mathrm{E}-05$ \\
\hline 44 & 77,6 & 29,8 & 70 & 8,8 & $2,7 \mathrm{E}-05$ \\
\hline 46 & 77,6 & 32,2 & 70 & 8,8 & 5,06E-05 \\
\hline 48 & 77,5 & 33,1 & 70 & 8,8 & 6,41E-05 \\
\hline 50 & 77,3 & 35 & 70 & 8,8 & 0,000105 \\
\hline 52 & 77,2 & 36,4 & 70 & 8,8 & 0,000152 \\
\hline 54 & 76,9 & 38,3 & 70 & 8,8 & 0,00025 \\
\hline 56 & 76,5 & 39,6 & 70 & 8,8 & 0,000351 \\
\hline 58 & 76,2 & 41,7 & 70 & 8,8 & 0,000608 \\
\hline 60 & 75,7 & 43 & 70 & 8,8 & 0,000855 \\
\hline 62 & 75,5 & 44,1 & 70 & 8,8 & 0,00114 \\
\hline 64 & 75,2 & 45,3 & 70 & 8,8 & 0,00156 \\
\hline 66 & 74,8 & 46,8 & 70 & 8,8 & 0,00231 \\
\hline 68 & 74,5 & 48,3 & 70 & 8,8 & 0,003421 \\
\hline 70 & 76,2 & 49,7 & 70 & 8,8 & 0,004934 \\
\hline 72 & 76,4 & 50,6 & 70 & 8,8 & 0,006244 \\
\hline 74 & 77,2 & 51,5 & 70 & 8,8 & 0,007902 \\
\hline 76 & 77 & 52,3 & 70 & 8,8 & 0,009742 \\
\hline 78 & 77 & 53,3 & 70 & 8,8 & 0,012655 \\
\hline 80 & 76,7 & 54,2 & 70 & 8,8 & 0,016016 \\
\hline 82 & 76,6 & 55,5 & 70 & 8,8 & 0,022505 \\
\hline
\end{tabular}




\begin{tabular}{|c|c|c|c|c|c|}
\hline Tempo (min) & $\mathrm{T}^{\circ} \mathrm{C}$ Meio (água) & $\mathrm{T}^{\circ} \mathrm{C}$ (amostra) & Tref & Z & TAXA LETAL \\
\hline 84 & 76,5 & 56,1 & 70 & 8,8 & 0,02633 \\
\hline 86 & 76,2 & 57,8 & 70 & 8,8 & 0,041081 \\
\hline 88 & 75,8 & 58 & 70 & 8,8 & 0,043288 \\
\hline 90 & 75,5 & 58,6 & 70 & 8,8 & 0,050646 \\
\hline 92 & 75,4 & 59,4 & 70 & 8,8 & 0,062439 \\
\hline 94 & 74,9 & 60,5 & 70 & 8,8 & 0,083263 \\
\hline 96 & 75,1 & 60,9 & 70 & 8,8 & 0,09245 \\
\hline 98 & 75,2 & 61,6 & 70 & 8,8 & 0,111034 \\
\hline 100 & 75,2 & 62,2 & 70 & 8,8 & 0,129908 \\
\hline 102 & 75,2 & 62,6 & 70 & 8,8 & 0,144242 \\
\hline 104 & 75,2 & 63,3 & 70 & 8,8 & 0,173235 \\
\hline 106 & 75,2 & 63,9 & 70 & 8,8 & 0,202683 \\
\hline 108 & 75,1 & 64,2 & 70 & 8,8 & 0,219235 \\
\hline 110 & 75,1 & 64,7 & 70 & 8,8 & 0,249878 \\
\hline 112 & 77,6 & 65,2 & 70 & 8,8 & 0,284804 \\
\hline 114 & 78,3 & 65,7 & 70 & 8,8 & 0,324611 \\
\hline 116 & 78,1 & 66,2 & 70 & 8,8 & 0,369983 \\
\hline 118 & 77,7 & 66,7 & 70 & 8,8 & 0,421697 \\
\hline 120 & 77,3 & 67,2 & 70 & 8,8 & 0,480638 \\
\hline 122 & 76,9 & 67,5 & 70 & 8,8 & 0,519887 \\
\hline 124 & 76,6 & 68 & 70 & 8,8 & 0,592553 \\
\hline 126 & 76,3 & 68,4 & 70 & 8,8 & 0,657933 \\
\hline 128 & 75,8 & 68,9 & 70 & 8,8 & 0,749894 \\
\hline 130 & 75,3 & 69,2 & 70 & 8,8 & 0,811131 \\
\hline 132 & 74,9 & 69,6 & 70 & 8,8 & 0,900628 \\
\hline 134 & 74,7 & 69,9 & 70 & 8,8 & 0,974174 \\
\hline 136 & 77,4 & 70,2 & 70 & 8,8 & 1,053725 \\
\hline 138 & 26,6 & 70,5 & 70 & 8,8 & 1,139773 \\
\hline 140 & 20,1 & 70,7 & 70 & 8,8 & 1,201007 \\
\hline 142 & 20,2 & 70,9 & 70 & 8,8 & 1,265531 \\
\hline 144 & 19,9 & 71,1 & 70 & 8,8 & 1,333521 \\
\hline 146 & 19,7 & 71,3 & 70 & 8,8 & 1,405165 \\
\hline 148 & 19,5 & 71,3 & 70 & 8,8 & 1,405165 \\
\hline 150 & 19,4 & 71 & 70 & 8,8 & 1,299081 \\
\hline 152 & 19,3 & 70,7 & 70 & 8,8 & 1,201007 \\
\hline 154 & 19,5 & 70 & 70 & 8,8 & 1 \\
\hline 156 & 19,3 & 69,5 & 70 & 8,8 & 0,877368 \\
\hline 158 & 19,4 & 68,8 & 70 & 8,8 & 0,730527 \\
\hline 160 & 22 & 67,5 & 70 & 8,8 & 0,519887 \\
\hline 162 & 20,2 & 66,2 & 70 & 8,8 & 0,369983 \\
\hline 164 & 19,7 & 65 & 70 & 8,8 & 0,270283 \\
\hline 166 & 19,4 & 63 & 70 & 8,8 & 0,160157 \\
\hline 168 & 19,4 & 61,8 & 70 & 8,8 & 0,116999 \\
\hline 170 & 19,4 & 59,5 & 70 & 8,8 & 0,064094 \\
\hline 172 & 19,4 & 58,8 & 70 & 8,8 & 0,053367 \\
\hline
\end{tabular}




\begin{tabular}{cccccc}
\hline Tempo (min) & $\mathrm{T}^{\circ} \mathrm{C}$ Meio (água) & $\mathrm{T}^{\circ} \mathrm{C}(\mathrm{amostra})$ & Tref & $\mathrm{Z}$ & TAXA LETAL \\
\hline 174 & 19,3 & 57,7 & 70 & 8,8 & 0,04002 \\
176 & 19,4 & 56,1 & 70 & 8,8 & 0,02633 \\
178 & 19,4 & 54,7 & 70 & 8,8 & 0,018254 \\
180 & 19,4 & 53,1 & 70 & 8,8 & 0,01201 \\
182 & 19,4 & 51,8 & 70 & 8,8 & 0,008547 \\
184 & 19,5 & 50,4 & 70 & 8,8 & 0,005926 \\
186 & 19,4 & 49 & 70 & 8,8 & 0,004108 \\
188 & 19,4 & 48 & 70 & 8,8 & 0,003162 \\
190 & 19,4 & 46,6 & 70 & 8,8 & 0,002192 \\
192 & 19,4 & 45,7 & 70 & 8,8 & 0,001732 \\
194 & 19,7 & 44,4 & 70 & 8,8 & 0,001233 \\
196 & 19,4 & 43,5 & 70 & 8,8 & 0,000974 \\
198 & 19,4 & 42,4 & 70 & 8,8 & 0,000731 \\
200 & 19,6 & 41,1 & 70 & 8,8 & 0,00052 \\
202 & 19,6 & 40,4 & 70 & 8,8 & 0,000433 \\
204 & 19,6 & 39,5 & 70 & 8,8 & 0,000342 \\
Somatório de taxas letais & & & & 24,40174 \\
\hline
\end{tabular}


APÊNDICE 2 - Aquecimento da amostra. Processamento 2 - $70^{\circ} \mathrm{C}$ em água

\begin{tabular}{|c|c|c|c|c|c|}
\hline Tempo(min) & $\mathrm{T}^{\circ} \mathrm{C}$ Meio (água) & $\mathrm{T}^{\circ} \mathrm{C}($ amostra $)$ & Tref & Z & TAXA LETAL \\
\hline 0 & 74,7 & 2,8 & 70 & 8,8 & 2,31E-08 \\
\hline 2 & 74,4 & 3,5 & 70 & 8,8 & 2,77E-08 \\
\hline 4 & 74,3 & 3,9 & 70 & 8,8 & $3,08 \mathrm{E}-08$ \\
\hline 6 & 74 & 4,3 & 70 & 8,8 & $3,42 \mathrm{E}-08$ \\
\hline 8 & 73,8 & 4,7 & 70 & 8,8 & $3,8 \mathrm{E}-08$ \\
\hline 10 & 73,9 & 5,6 & 70 & 8,8 & $4,81 \mathrm{E}-08$ \\
\hline 12 & 74 & 6,4 & 70 & 8,8 & $5,93 \mathrm{E}-08$ \\
\hline 14 & 73,8 & 7,8 & 70 & 8,8 & $8,55 \mathrm{E}-08$ \\
\hline 16 & 73,8 & 9,3 & 70 & 8,8 & $1,27 \mathrm{E}-07$ \\
\hline 18 & 73,7 & 11,1 & 70 & 8,8 & 2,03E-07 \\
\hline 20 & 74,7 & 13,1 & 70 & 8,8 & $3,42 \mathrm{E}-07$ \\
\hline 22 & 74,7 & 15,1 & 70 & 8,8 & 5,77E-07 \\
\hline 24 & 74,7 & 17,4 & 70 & 8,8 & $1,05 E-06$ \\
\hline 26 & 74,7 & 19,6 & 70 & 8,8 & 1,87E-06 \\
\hline 28 & 74,8 & 22,1 & 70 & 8,8 & 3,6E-06 \\
\hline 30 & 75,3 & 24,6 & 70 & 8,8 & 6,93E-06 \\
\hline 32 & 78,6 & 26,9 & 70 & 8,8 & 1,27E-05 \\
\hline 34 & 79,5 & 29 & 70 & 8,8 & 2,19E-05 \\
\hline 36 & 78,8 & 31,3 & 70 & 8,8 & 4E-05 \\
\hline 38 & 79,1 & 33,3 & 70 & 8,8 & $6,75 \mathrm{E}-05$ \\
\hline 40 & 78,4 & 35,6 & 70 & 8,8 & 0,000123 \\
\hline 42 & 78 & 38,2 & 70 & 8,8 & 0,000243 \\
\hline 44 & 77,5 & 40,2 & 70 & 8,8 & 0,000411 \\
\hline 46 & 77,2 & 42,4 & 70 & 8,8 & 0,000731 \\
\hline 48 & 76,6 & 44,5 & 70 & 8,8 & 0,001266 \\
\hline 50 & 76,2 & 46 & 70 & 8,8 & 0,001874 \\
\hline 52 & 75,7 & 47,8 & 70 & 8,8 & 0,003001 \\
\hline 54 & 75,5 & 49,5 & 70 & 8,8 & 0,004682 \\
\hline 56 & 75 & 51 & 70 & 8,8 & 0,006933 \\
\hline 58 & 74,6 & 52,5 & 70 & 8,8 & 0,010265 \\
\hline 60 & 74,3 & 53,8 & 70 & 8,8 & 0,014424 \\
\hline 62 & 73,8 & 55,2 & 70 & 8,8 & 0,020806 \\
\hline 64 & 73,6 & 56,6 & 70 & 8,8 & 0,03001 \\
\hline 66 & 73,1 & 57,6 & 70 & 8,8 & 0,038986 \\
\hline
\end{tabular}




\begin{tabular}{|c|c|c|c|c|c|}
\hline Tempo (min) & $\mathrm{T}^{\circ} \mathrm{C}$ Meio (água) & $\mathrm{T}^{\circ} \mathrm{C}$ (amostra) & Tref & Z & TAXA LETAL \\
\hline 68 & 73,2 & 58,5 & 70 & 8,8 & 0,049338 \\
\hline 70 & 73,4 & 59,5 & 70 & 8,8 & 0,064094 \\
\hline 72 & 76,7 & 60,4 & 70 & 8,8 & 0,081113 \\
\hline 74 & 76,7 & 61,2 & 70 & 8,8 & 0,1 \\
\hline 76 & 76,7 & 62 & 70 & 8,8 & 0,123285 \\
\hline 78 & 76,5 & 62,7 & 70 & 8,8 & 0,148066 \\
\hline 80 & 76,1 & 63,3 & 70 & 8,8 & 0,173235 \\
\hline 82 & 75,7 & 64 & 70 & 8,8 & 0,208057 \\
\hline 84 & 75,5 & 64,7 & 70 & 8,8 & 0,249878 \\
\hline 86 & 75,3 & 65,3 & 70 & 8,8 & 0,292354 \\
\hline 88 & 74,8 & 65,8 & 70 & 8,8 & 0,333217 \\
\hline 90 & 74,4 & 66,5 & 70 & 8,8 & 0,400196 \\
\hline 92 & 74,1 & 67 & 70 & 8,8 & 0,456132 \\
\hline 94 & 73,8 & 67,5 & 70 & 8,8 & 0,519887 \\
\hline 96 & 73,6 & 68 & 70 & 8,8 & 0,592553 \\
\hline 98 & 76,7 & 68,4 & 70 & 8,8 & 0,657933 \\
\hline 100 & 76,6 & 68,7 & 70 & 8,8 & 0,71166 \\
\hline 102 & 76,2 & 69,1 & 70 & 8,8 & 0,790182 \\
\hline 104 & 76 & 69,5 & 70 & 8,8 & 0,877368 \\
\hline 106 & 75,6 & 69,8 & 70 & 8,8 & 0,949014 \\
\hline 108 & 75,2 & 70 & 70 & 8,8 & 1 \\
\hline 110 & 74,8 & 70,3 & 70 & 8,8 & 1,08166 \\
\hline 112 & 74,5 & 70,6 & 70 & 8,8 & 1,169989 \\
\hline 114 & 24 & 70,9 & 70 & 8,8 & 1,265531 \\
\hline 116 & 24 & 71,2 & 70 & 8,8 & 1,368875 \\
\hline 118 & 24 & 71,2 & 70 & 8,8 & 1,368875 \\
\hline 120 & 24 & 71,4 & 70 & 8,8 & 1,442417 \\
\hline 122 & 24 & 71,6 & 70 & 8,8 & 1,519911 \\
\hline 124 & 24 & 71,7 & 70 & 8,8 & 1,560206 \\
\hline 126 & 24 & 71,4 & 70 & 8,8 & 1,442417 \\
\hline 128 & 24 & 70,7 & 70 & 8,8 & 1,201007 \\
\hline 130 & 24 & 70,2 & 70 & 8,8 & 1,053725 \\
\hline 132 & 24 & 69,1 & 70 & 8,8 & 0,790182 \\
\hline 134 & 24 & 67,8 & 70 & 8,8 & 0,562341 \\
\hline 136 & 19,3 & 66,3 & 70 & 8,8 & 0,379792 \\
\hline 138 & 19,3 & 64,6 & 70 & 8,8 & 0,243424 \\
\hline
\end{tabular}




\begin{tabular}{cccccc}
\hline Tempo $(\mathrm{min})$ & $\mathrm{T}^{\circ} \mathrm{C}$ Meio (água) & $\mathrm{T}^{\circ} \mathrm{C}($ amostra $)$ & Tref & $\mathrm{Z}$ & TAXA LETAL \\
\hline 140 & 19,3 & 62,9 & 70 & 8,8 & 0,156021 \\
142 & 19,3 & 61 & 70 & 8,8 & 0,094901 \\
144 & 19,3 & 59,3 & 70 & 8,8 & 0,060826 \\
146 & 19,3 & 57,4 & 70 & 8,8 & 0,036998 \\
148 & 19,2 & 54,7 & 70 & 8,8 & 0,018254 \\
150 & 19,2 & 53,7 & 70 & 8,8 & 0,014052 \\
152 & 19,2 & 52,4 & 70 & 8,8 & 0,01 \\
154 & 19,1 & 50,7 & 70 & 8,8 & 0,006409 \\
156 & 19,2 & 49 & 70 & 8,8 & 0,004108 \\
158 & 19,1 & 47,3 & 70 & 8,8 & 0,002633 \\
160 & 19 & 45,9 & 70 & 8,8 & 0,001825 \\
162 & 19,1 & 44,5 & 70 & 8,8 & 0,001266 \\
164 & 19 & 43,3 & 70 & 8,8 & 0,000925 \\
166 & 19,2 & 42,1 & 70 & 8,8 & 0,000675 \\
168 & 19 & 41,1 & 70 & 8,8 & 0,00052 \\
170 & 19,2 & 40 & 70 & 8,8 & 0,00039 \\
Somatório das taxas letais & & & & 25,77163 \\
\hline
\end{tabular}


APÊNDICE 3 - Aquecimento da amostra. Processamento $1-70^{\circ} \mathrm{C}$ em vapor

\begin{tabular}{|c|c|c|c|c|c|}
\hline Tempo(min) & $\mathrm{T}^{\circ} \mathrm{C}$ Meio (estufa) & $\mathrm{T}^{\circ} \mathrm{C}$ (amostra) & Tref & $Z$ & TAXA LETAL \\
\hline 0 & 72,8 & 3,8 & 70 & 8,8 & $3 E-08$ \\
\hline 2 & 72,8 & 4,1 & 70 & 8,8 & $3,25 E-08$ \\
\hline 4 & 83,6 & 4,5 & 70 & 8,8 & $3,6 \mathrm{E}-08$ \\
\hline 6 & 82 & 4,9 & 70 & 8,8 & $4 \mathrm{E}-08$ \\
\hline 8 & 81,6 & 5,4 & 70 & 8,8 & 4,56E-08 \\
\hline 10 & 76,7 & 6,2 & 70 & 8,8 & $5,62 E-08$ \\
\hline 12 & 75,1 & 7,5 & 70 & 8,8 & 7,9E-08 \\
\hline 14 & 74,4 & 8,5 & 70 & 8,8 & $1,03 E-07$ \\
\hline 16 & 75,3 & 9,9 & 70 & 8,8 & $1,48 \mathrm{E}-07$ \\
\hline 18 & 73,8 & 11,4 & 70 & 8,8 & $2,19 \mathrm{E}-07$ \\
\hline 20 & 75,2 & 13,2 & 70 & 8,8 & 3,51E-07 \\
\hline 22 & 73,4 & 14,8 & 70 & 8,8 & $5,34 \mathrm{E}-07$ \\
\hline 24 & 75,6 & 16,6 & 70 & 8,8 & $8,55 \mathrm{E}-07$ \\
\hline 26 & 76,4 & 18,4 & 70 & 8,8 & 1,37E-06 \\
\hline 28 & 76,8 & 20,6 & 70 & 8,8 & 2,43E-06 \\
\hline 30 & 76,4 & 22,1 & 70 & 8,8 & 3,6E-06 \\
\hline 32 & 75,8 & 23,9 & 70 & 8,8 & 5,77E-06 \\
\hline 34 & 76,8 & 25,9 & 70 & 8,8 & 9,74E-06 \\
\hline 36 & 75,5 & 27,6 & 70 & 8,8 & 1,52E-05 \\
\hline 38 & 75,3 & 29,7 & 70 & 8,8 & 2,63E-05 \\
\hline 40 & 76,4 & 31,3 & 70 & 8,8 & 4E-05 \\
\hline 42 & 74,9 & 33,5 & 70 & 8,8 & $7,12 \mathrm{E}-05$ \\
\hline 44 & 74,8 & 34,8 & 70 & 8,8 & 0,0001 \\
\hline 46 & 74,7 & 36,7 & 70 & 8,8 & 0,000164 \\
\hline 48 & 74,8 & 37,7 & 70 & 8,8 & 0,000214 \\
\hline 50 & 74,8 & 39,4 & 70 & 8,8 & 0,000333 \\
\hline 52 & 74,8 & 40,7 & 70 & 8,8 & 0,000468 \\
\hline 54 & 75,9 & 42,7 & 70 & 8,8 & 0,00079 \\
\hline 56 & 76 & 43,5 & 70 & 8,8 & 0,000974 \\
\hline 58 & 75,3 & 45 & 70 & 8,8 & 0,001442 \\
\hline 60 & 74,6 & 46 & 70 & 8,8 & 0,001874 \\
\hline 62 & 74,6 & 47,8 & 70 & 8,8 & 0,003001 \\
\hline 64 & 76,2 & 48,6 & 70 & 8,8 & 0,0037 \\
\hline 66 & 75,6 & 50 & 70 & 8,8 & 0,005337 \\
\hline 68 & 76,2 & 51 & 70 & 8,8 & 0,006933 \\
\hline 70 & 75,6 & 52,2 & 70 & 8,8 & 0,00949 \\
\hline
\end{tabular}




\begin{tabular}{|c|c|c|c|c|c|}
\hline Tempo (min) & $\mathrm{T}^{\circ} \mathrm{C}$ Meio (estufa) & $\mathrm{T}^{\circ} \mathrm{C}$ (amostra) & Tref & Z & TAXA LETAL \\
\hline 72 & 75,9 & 53,2 & 70 & 8,8 & 0,012328 \\
\hline 74 & 75,4 & 54,3 & 70 & 8,8 & 0,01644 \\
\hline 76 & 75,2 & 55,1 & 70 & 8,8 & 0,020268 \\
\hline 78 & 75,3 & 56 & 70 & 8,8 & 0,02565 \\
\hline 80 & 75,7 & 56 & 70 & 8,8 & 0,02565 \\
\hline 82 & 75,1 & 56,9 & 70 & 8,8 & 0,032461 \\
\hline 84 & 74,8 & 57,7 & 70 & 8,8 & 0,04002 \\
\hline 86 & 74,8 & 58,7 & 70 & 8,8 & 0,051989 \\
\hline 88 & 75,6 & 59,3 & 70 & 8,8 & 0,060826 \\
\hline 90 & 75,2 & 60,4 & 70 & 8,8 & 0,081113 \\
\hline 92 & 75,1 & 60,9 & 70 & 8,8 & 0,09245 \\
\hline 94 & 74,9 & 61,4 & 70 & 8,8 & 0,105372 \\
\hline 96 & 74,8 & 62 & 70 & 8,8 & 0,123285 \\
\hline 98 & 75,1 & 62,7 & 70 & 8,8 & 0,148066 \\
\hline 100 & 75,6 & 63,2 & 70 & 8,8 & 0,168761 \\
\hline 102 & 76,3 & 63,7 & 70 & 8,8 & 0,192349 \\
\hline 104 & 74,8 & 64,4 & 70 & 8,8 & 0,231013 \\
\hline 106 & 74,8 & 64,7 & 70 & 8,8 & 0,249878 \\
\hline 108 & 75,6 & 65,7 & 70 & 8,8 & 0,324611 \\
\hline 110 & 75,4 & 65,5 & 70 & 8,8 & 0,308061 \\
\hline 112 & 75,4 & 66 & 70 & 8,8 & 0,351119 \\
\hline 114 & 75,2 & 66,4 & 70 & 8,8 & 0,38986 \\
\hline 116 & 75,2 & 66,8 & 70 & 8,8 & 0,432876 \\
\hline 118 & 75,2 & 67,2 & 70 & 8,8 & 0,480638 \\
\hline 120 & 75,7 & 67,5 & 70 & 8,8 & 0,519887 \\
\hline 122 & 74,8 & 68 & 70 & 8,8 & 0,592553 \\
\hline 124 & 76 & 68,3 & 70 & 8,8 & 0,640941 \\
\hline 126 & 75,3 & 68,5 & 70 & 8,8 & 0,675376 \\
\hline 128 & 75,9 & 68,8 & 70 & 8,8 & 0,730527 \\
\hline 130 & 75,3 & 69,1 & 70 & 8,8 & 0,790182 \\
\hline 132 & 75,4 & 69,4 & 70 & 8,8 & 0,854709 \\
\hline 134 & 75,4 & 69,6 & 70 & 8,8 & 0,900628 \\
\hline 136 & 75,5 & 69,8 & 70 & 8,8 & 0,949014 \\
\hline 138 & 75,2 & 70,1 & 70 & 8,8 & 1,026511 \\
\hline 140 & 75,3 & 70,3 & 70 & 8,8 & 1,08166 \\
\hline 142 & 75,6 & 70,5 & 70 & 8,8 & 1,139773 \\
\hline 144 & 74,8 & 70,7 & 70 & 8,8 & 1,201007 \\
\hline 146 & 26,6 & 70,8 & 70 & 8,8 & 1,232847 \\
\hline
\end{tabular}




\begin{tabular}{cccccc}
\hline Tempo (min) & $\mathrm{T}^{\circ} \mathrm{C}$ Meio (estufa) & $\mathrm{T}^{\circ} \mathrm{C}$ (amostra) & Tref & $\mathrm{Z}$ & TAXA LETAL \\
\hline 148 & 20,1 & 70,8 & 70 & 8,8 & 1,232847 \\
150 & 20,2 & 70,8 & 70 & 8,8 & 1,232847 \\
152 & 19,9 & 71,3 & 70 & 8,8 & 1,405165 \\
154 & 19,7 & 71,3 & 70 & 8,8 & 1,405165 \\
156 & 19,5 & 71,5 & 70 & 8,8 & 1,480657 \\
158 & 19,4 & 71 & 70 & 8,8 & 1,299081 \\
160 & 19,3 & 70,8 & 70 & 8,8 & 1,232847 \\
162 & 19,5 & 69,1 & 70 & 8,8 & 0,790182 \\
164 & 19,3 & 68,7 & 70 & 8,8 & 0,71166 \\
166 & 19,4 & 68,3 & 70 & 8,8 & 0,640941 \\
168 & 22 & 66,9 & 70 & 8,8 & 0,444352 \\
170 & 20,2 & 65,9 & 70 & 8,8 & 0,342051 \\
172 & 19,7 & 64,7 & 70 & 8,8 & 0,249878 \\
174 & 19,4 & 61,4 & 70 & 8,8 & 0,105372 \\
176 & 19,4 & 60,1 & 70 & 8,8 & 0,074989 \\
178 & 19,4 & 58,1 & 70 & 8,8 & 0,044435 \\
180 & 19,4 & 56,7 & 70 & 8,8 & 0,030806 \\
182 & 19,3 & 54,6 & 70 & 8,8 & 0,017783 \\
184 & 19,4 & 53,6 & 70 & 8,8 & 0,013689 \\
186 & 19,4 & 52 & 70 & 8,8 & 0,009006 \\
188 & 19,4 & 50,6 & 70 & 8,8 & 0,006244 \\
190 & 19,4 & 48,3 & 70 & 8,8 & 0,003421 \\
192 & 19,5 & 47 & 70 & 8,8 & 0,002434 \\
194 & 19,4 & 46,4 & 70 & 8,8 & 0,002081 \\
196 & 19,4 & 45,2 & 70 & 8,8 & 0,00152 \\
198 & 19,4 & 43,9 & 70 & 8,8 & 0,001082 \\
200 & 19,4 & 42,9 & 70 & 8,8 & 0,000833 \\
202 & 19,7 & 41,8 & 70 & 8,8 & 0,000624 \\
204 & 19,4 & 40,7 & 70 & 8,8 & 0,000468 \\
206 & 19,4 & 40 & 70 & 8,8 & 0,00039 \\
Somatório das taxas letais & & & & & 29,11855 \\
\hline & & & & & \\
\hline
\end{tabular}


APÊNDICE 4 - Aquecimento da amostra - Processamento $2-70^{\circ} \mathrm{C}$ em vapor

\begin{tabular}{|c|c|c|c|c|c|}
\hline Tempo(min) & $\mathrm{T}^{\circ} \mathrm{C}$ Meio (estufa) & $\mathrm{T}^{\circ} \mathrm{C}$ (amostra) & Tref & $Z$ & TAXA LETAL \\
\hline 0 & 76,4 & 11 & 70 & 8,8 & 1,97449E-07 \\
\hline 2 & 75,2 & 12,3 & 70 & 8,8 & $2,77448 \mathrm{E}-07$ \\
\hline 4 & 74,3 & 13 & 70 & 8,8 & 3,33217E-07 \\
\hline 6 & 74,4 & 14,5 & 70 & 8,8 & 4,9338E-07 \\
\hline 8 & 74,3 & 16,1 & 70 & 8,8 & 7,49894E-07 \\
\hline 10 & 73,7 & 18,7 & 70 & 8,8 & 1,48066E-06 \\
\hline 12 & 74,8 & 20,3 & 70 & 8,8 & 2,25047E-06 \\
\hline 14 & 74,2 & 22,2 & 70 & 8,8 & 3,69983E-06 \\
\hline 16 & 75 & 24,1 & 70 & 8,8 & 6,08262E-06 \\
\hline 18 & 74 & 26 & 70 & 8,8 & 0,00001 \\
\hline 20 & 74,8 & 28 & 70 & 8,8 & 1,68761E-05 \\
\hline 22 & 76,1 & 29,9 & 70 & 8,8 & 2,77448E-05 \\
\hline 24 & 75,6 & 32,4 & 70 & 8,8 & 5,3367E-05 \\
\hline 26 & 74 & 34,4 & 70 & 8,8 & $9,00628 E-05$ \\
\hline 28 & 73,6 & 36,8 & 70 & 8,8 & 0,000168761 \\
\hline 30 & 74,5 & 39 & 70 & 8,8 & 0,000300105 \\
\hline 32 & 75,4 & 40,6 & 70 & 8,8 & 0,000456132 \\
\hline 34 & 74,7 & 43,2 & 70 & 8,8 & 0,000900628 \\
\hline 36 & 74,6 & 44 & 70 & 8,8 & 0,001110336 \\
\hline 38 & 76 & 45,2 & 70 & 8,8 & 0,001519911 \\
\hline 40 & 76,2 & 46,1 & 70 & 8,8 & 0,001923494 \\
\hline 42 & 75,3 & 47,9 & 70 & 8,8 & 0,003080607 \\
\hline 44 & 75,1 & 49,7 & 70 & 8,8 & 0,004933803 \\
\hline 46 & 74,9 & 50,4 & 70 & 8,8 & 0,005925531 \\
\hline 48 & 76,4 & 51,6 & 70 & 8,8 & 0,008111308 \\
\hline 50 & 75,7 & 53,2 & 70 & 8,8 & 0,012328467 \\
\hline 52 & 75 & 54 & 70 & 8,8 & 0,015199111 \\
\hline 54 & 74,8 & 55,3 & 70 & 8,8 & 0,021357256 \\
\hline 56 & 76 & 56,1 & 70 & 8,8 & 0,026330223 \\
\hline 58 & 76,6 & 57,1 & 70 & 8,8 & 0,034205104 \\
\hline 60 & 74,8 & 58 & 70 & 8,8 & 0,043287613 \\
\hline 62 & 74,4 & 59,6 & 70 & 8,8 & 0,065793322 \\
\hline 64 & 74,8 & 60 & 70 & 8,8 & 0,073052715 \\
\hline 66 & 74,8 & 61,2 & 70 & 8,8 & 0,1 \\
\hline 68 & 75,5 & 61,3 & 70 & 8,8 & 0,102651107 \\
\hline 70 & 75,3 & 62 & 70 & 8,8 & 0,123284674 \\
\hline 72 & 74,8 & 62,6 & 70 & 8,8 & 0,144241726 \\
\hline 74 & 76,4 & 63,1 & 70 & 8,8 & 0,164402755 \\
\hline
\end{tabular}




\begin{tabular}{|c|c|c|c|c|c|}
\hline Tempo (min) & $\mathrm{T}^{\circ} \mathrm{C}$ Meio (estufa) & $\mathrm{T}^{\circ} \mathrm{C}$ (amostra) & Tref & Z & TAXA LETAL \\
\hline 76 & 76 & 63,9 & 70 & 8,8 & 0,2026834 \\
\hline 78 & 75,8 & 64,3 & 70 & 8,8 & 0,225046741 \\
\hline 80 & 75,4 & 64,8 & 70 & 8,8 & 0,256502091 \\
\hline 82 & 75 & 65,4 & 70 & 8,8 & 0,300104652 \\
\hline 84 & 76,2 & 65,9 & 70 & 8,8 & 0,342051035 \\
\hline 86 & 76,4 & 66,3 & 70 & 8,8 & 0,379791687 \\
\hline 88 & 76,4 & 66,8 & 70 & 8,8 & 0,432876128 \\
\hline 90 & 77 & 67,2 & 70 & 8,8 & 0,480638086 \\
\hline 92 & 76,4 & 67,8 & 70 & 8,8 & 0,562341325 \\
\hline 94 & 76,2 & 68 & 70 & 8,8 & 0,592553098 \\
\hline 96 & 75,7 & 68,6 & 70 & 8,8 & 0,693280669 \\
\hline 98 & 74,4 & 68,8 & 70 & 8,8 & 0,730527154 \\
\hline 100 & 76,8 & 69,2 & 70 & 8,8 & 0,811130831 \\
\hline 102 & 76,4 & 69,5 & 70 & 8,8 & 0,877368056 \\
\hline 104 & 76,4 & 69,9 & 70 & 8,8 & 0,974173617 \\
\hline 106 & 76,1 & 70,1 & 70 & 8,8 & 1,026511068 \\
\hline 108 & 75,2 & 70,8 & 70 & 8,8 & 1,232846739 \\
\hline 110 & 75,8 & 70,8 & 70 & 8,8 & 1,232846739 \\
\hline 112 & 25 & 70,8 & 70 & 8,8 & 1,232846739 \\
\hline 114 & 25 & 70,8 & 70 & 8,8 & 1,232846739 \\
\hline 116 & 19,3 & 70,8 & 70 & 8,8 & 1,232846739 \\
\hline 118 & 19,3 & 71,2 & 70 & 8,8 & 1,36887451 \\
\hline 120 & 19,3 & 71,3 & 70 & 8,8 & 1,405164835 \\
\hline 122 & 19,3 & 70,8 & 70 & 8,8 & 1,232846739 \\
\hline 124 & 19,3 & 69,9 & 70 & 8,8 & 0,974173617 \\
\hline 126 & 19,3 & 69,8 & 70 & 8,8 & 0,949014236 \\
\hline 128 & 19,3 & 68,8 & 70 & 8,8 & 0,730527154 \\
\hline 130 & 19,2 & 67,8 & 70 & 8,8 & 0,562341325 \\
\hline 132 & 19,2 & 66,1 & 70 & 8,8 & 0,360427718 \\
\hline 134 & 19,1 & 64,4 & 70 & 8,8 & 0,23101297 \\
\hline 136 & 19,2 & 62,7 & 70 & 8,8 & 0,148065728 \\
\hline 138 & 19,1 & 61,2 & 70 & 8,8 & 0,1 \\
\hline 140 & 19,2 & 59,4 & 70 & 8,8 & 0,0624388 \\
\hline 142 & 19,3 & 57,8 & 70 & 8,8 & 0,041080561 \\
\hline 144 & 19,3 & 55,8 & 70 & 8,8 & 0,024342414 \\
\hline 146 & 19,3 & 54,2 & 70 & 8,8 & 0,016015683 \\
\hline 148 & 19,3 & 52,4 & 70 & 8,8 & 0,01 \\
\hline 150 & 19,2 & 51,2 & 70 & 8,8 & 0,007305272 \\
\hline
\end{tabular}




\begin{tabular}{cccccc}
\hline Tempo $(\mathrm{min})$ & $\mathrm{T}^{\circ} \mathrm{C}$ Meio (estufa) & $\mathrm{T}^{\circ} \mathrm{C}($ amostra) & Tref & $\mathrm{Z}$ & TAXA LETAL \\
\hline 152 & 19,2 & 49,6 & 70 & 8,8 & 0,004806381 \\
154 & 19,3 & 47,9 & 70 & 8,8 & 0,003080607 \\
156 & 19,3 & 46,1 & 70 & 8,8 & 0,001923494 \\
158 & 19,1 & 45,1 & 70 & 8,8 & 0,001480657 \\
160 & 19,1 & 43,8 & 70 & 8,8 & 0,001053725 \\
162 & 19,2 & 42,3 & 70 & 8,8 & 0,00071166 \\
164 & 19,1 & 41,5 & 70 & 8,8 & 0,00057725 \\
166 & 19,1 & 40,4 & 70 & 8,8 & 0,000432876 \\
168 & 19,1 & 40 & 70 & 8,8 & 0,00038986 \\
Somatório das taxas letais & & & & 24,24467971 \\
\hline
\end{tabular}


APÊNDICE 5 - Aquecimento da amostra - Processamento 1 - $80^{\circ} \mathrm{C}$ em água

\begin{tabular}{|c|c|c|c|c|c|}
\hline Tempo(min) & $\mathrm{T}^{\circ} \mathrm{C}$ Meio (água) & $\mathrm{T}^{\circ} \mathrm{C}$ (amostra) & Tref & $Z$ & TAXA LETAL \\
\hline 0 & 89,7 & 3 & 80 & 8,8 & 1,78E-09 \\
\hline 2 & 88,4 & 3,7 & 80 & 8,8 & 2,14E-09 \\
\hline 4 & 87,9 & 3,9 & 80 & 8,8 & $2,25 E-09$ \\
\hline 6 & 87,8 & 4,3 & 80 & 8,8 & 2,5E-09 \\
\hline 8 & 90,4 & 5 & 80 & 8,8 & 3E-09 \\
\hline 10 & 90,2 & 6,1 & 80 & 8,8 & 4E-09 \\
\hline 12 & 90,1 & 7,5 & 80 & 8,8 & 5,77E-09 \\
\hline 14 & 90,1 & 9,3 & 80 & 8,8 & $9,25 E-09$ \\
\hline 16 & 89,9 & 11,2 & 80 & 8,8 & 1,52E-08 \\
\hline 18 & 89,9 & 13,5 & 80 & 8,8 & $2,77 E-08$ \\
\hline 20 & 89,7 & 15,9 & 80 & 8,8 & $5,2 E-08$ \\
\hline 22 & 90,4 & 18,4 & 80 & 8,8 & $1 E-07$ \\
\hline 24 & 90,5 & 20,9 & 80 & 8,8 & 1,92E-07 \\
\hline 26 & 89,8 & 23,5 & 80 & 8,8 & $3,8 \mathrm{E}-07$ \\
\hline 28 & 89,9 & 26,3 & 80 & 8,8 & 7,9E-07 \\
\hline 30 & 91,5 & 28,7 & 80 & 8,8 & 1,48E-06 \\
\hline 32 & 90,8 & 31,1 & 80 & 8,8 & 2,77E-06 \\
\hline 34 & 90,2 & 33,5 & 80 & 8,8 & $5,2 \mathrm{E}-06$ \\
\hline 36 & 89,8 & 36,1 & 80 & 8,8 & 1,03E-05 \\
\hline 38 & 89,8 & 38,5 & 80 & 8,8 & $1,92 \mathrm{E}-05$ \\
\hline 40 & 90 & 40,7 & 80 & 8,8 & $3,42 E-05$ \\
\hline 42 & 89,8 & 43,9 & 80 & 8,8 & 7,9E-05 \\
\hline 44 & 90,4 & 45,8 & 80 & 8,8 & 0,00013 \\
\hline 46 & 90,3 & 47,7 & 80 & 8,8 & 0,000214 \\
\hline 48 & 90,5 & 49,7 & 80 & 8,8 & 0,00036 \\
\hline 50 & 90,6 & 51,6 & 80 & 8,8 & 0,000593 \\
\hline 52 & 90,6 & 53,2 & 80 & 8,8 & 0,000901 \\
\hline 54 & 90,7 & 55 & 80 & 8,8 & 0,001442 \\
\hline 56 & 90,6 & 56,6 & 80 & 8,8 & 0,002192 \\
\hline 58 & 90,8 & 58,3 & 80 & 8,8 & 0,003421 \\
\hline 60 & 90,6 & 59,7 & 80 & 8,8 & 0,004934 \\
\hline 62 & 90,4 & 61,1 & 80 & 8,8 & 0,007117 \\
\hline 64 & 90,6 & 62,5 & 80 & 8,8 & 0,010265 \\
\hline 66 & 90,5 & 63,8 & 80 & 8,8 & 0,014424 \\
\hline 68 & 90,5 & 65,1 & 80 & 8,8 & 0,020268 \\
\hline 70 & 90,5 & 66,2 & 80 & 8,8 & 0,027028 \\
\hline 72 & 90,5 & 67,3 & 80 & 8,8 & 0,036043 \\
\hline 74 & 90,7 & 68,5 & 80 & 8,8 & 0,049338 \\
\hline 76 & 90,6 & 69,5 & 80 & 8,8 & 0,064094 \\
\hline 78 & 90,3 & 70,4 & 80 & 8,8 & 0,081113 \\
\hline 80 & 90,4 & 71,3 & 80 & 8,8 & 0,102651 \\
\hline 82 & 90,6 & 72,2 & 80 & 8,8 & 0,129908 \\
\hline
\end{tabular}




\begin{tabular}{|c|c|c|c|c|c|}
\hline Tempo (min) & $\mathrm{T}^{\circ} \mathrm{C}$ Meio (água) & $\mathrm{T}^{\circ} \mathrm{C}$ (amostra) & Tref & $Z$ & TAXA LETAL \\
\hline 84 & 90,5 & 73,1 & 80 & 8,8 & 0,164403 \\
\hline 86 & 90,6 & 73,9 & 80 & 8,8 & 0,202683 \\
\hline 88 & 90,4 & 74,7 & 80 & 8,8 & 0,249878 \\
\hline 90 & 90,4 & 75,5 & 80 & 8,8 & 0,308061 \\
\hline 92 & 90,6 & 76,2 & 80 & 8,8 & 0,369983 \\
\hline 94 & 90,6 & 76,7 & 80 & 8,8 & 0,421697 \\
\hline 96 & 90,6 & 77,5 & 80 & 8,8 & 0,519887 \\
\hline 98 & 90,5 & 78,1 & 80 & 8,8 & 0,608262 \\
\hline 100 & 90,3 & 78,7 & 80 & 8,8 & 0,711661 \\
\hline 102 & 90,5 & 79,2 & 80 & 8,8 & 0,811131 \\
\hline 104 & 90,4 & 79,8 & 80 & 8,8 & 0,949014 \\
\hline 106 & 90,3 & 80 & 80 & 8,8 & 1 \\
\hline 108 & 90,4 & 80,5 & 80 & 8,8 & 1,139773 \\
\hline 110 & 90,2 & 81 & 80 & 8,8 & 1,299081 \\
\hline 112 & 90,3 & 81,4 & 80 & 8,8 & 1,442417 \\
\hline 114 & 24,3 & 81,8 & 80 & 8,8 & 1,601568 \\
\hline 116 & 25,7 & 82 & 80 & 8,8 & 1,687612 \\
\hline 118 & 27,4 & 82,4 & 80 & 8,8 & 1,873817 \\
\hline 120 & 21,2 & 82,7 & 80 & 8,8 & 2,026834 \\
\hline 122 & 20,8 & 82,8 & 80 & 8,8 & 2,080568 \\
\hline 124 & 19,8 & 82,8 & 80 & 8,8 & 2,080568 \\
\hline 126 & 19,4 & 82,2 & 80 & 8,8 & 1,778279 \\
\hline 128 & 19,4 & 81,1 & 80 & 8,8 & 1,333521 \\
\hline 130 & 19,3 & 79,7 & 80 & 8,8 & 0,924505 \\
\hline 132 & 19,3 & 78 & 80 & 8,8 & 0,592553 \\
\hline 134 & 19,3 & 76,1 & 80 & 8,8 & 0,360428 \\
\hline 136 & 19,3 & 74,1 & 80 & 8,8 & 0,213573 \\
\hline 138 & 19,3 & 72 & 80 & 8,8 & 0,123285 \\
\hline 140 & 19,3 & 69,3 & 80 & 8,8 & 0,060826 \\
\hline 142 & 19,3 & 67,9 & 80 & 8,8 & 0,04217 \\
\hline 144 & 19,2 & 65,3 & 80 & 8,8 & 0,021357 \\
\hline 146 & 19,3 & 63,8 & 80 & 8,8 & 0,014424 \\
\hline 148 & 19,3 & 61,6 & 80 & 8,8 & 0,008111 \\
\hline 150 & 19,3 & 59,8 & 80 & 8,8 & 0,005065 \\
\hline 152 & 19,3 & 57,9 & 80 & 8,8 & 0,003081 \\
\hline 154 & 19,3 & 56,1 & 80 & 8,8 & 0,001923 \\
\hline 156 & 19,3 & 54,4 & 80 & 8,8 & 0,001233 \\
\hline 158 & 19,3 & 52,7 & 80 & 8,8 & 0,00079 \\
\hline 160 & 19,3 & 51,1 & 80 & 8,8 & 0,00052 \\
\hline 162 & 19,3 & 49,4 & 80 & 8,8 & 0,000333 \\
\hline 164 & 19,2 & 48 & 80 & 8,8 & 0,000231 \\
\hline 166 & 19,3 & 46,6 & 80 & 8,8 & 0,00016 \\
\hline 168 & 19,3 & 45,1 & 80 & 8,8 & 0,000108 \\
\hline 170 & 19,3 & 43,4 & 80 & 8,8 & $6,93 E-05$ \\
\hline 172 & 19,3 & 41,8 & 80 & 8,8 & 4,56E-05 \\
\hline
\end{tabular}




\begin{tabular}{cccccc}
\hline Tempo $(\mathrm{min})$ & $\mathrm{T}^{\circ} \mathrm{C}$ Meio (água) & $\mathrm{T}^{\circ} \mathrm{C}($ amostra) & Tref & $\mathrm{Z}$ & $\mathrm{TAXA} L E T A L$ \\
\hline 174 & 19,2 & 41,6 & 80 & 8,8 & $4,33 \mathrm{E}-05$ \\
176 & 19,2 & 40,4 & 80 & 8,8 & $3,16 \mathrm{E}-05$ \\
178 & 19,3 & 40 & 80 & 8,8 & $2,85 \mathrm{E}-05$ \\
\multicolumn{2}{l}{ Somatório das taxas letais } & & & & 27,59218 \\
\hline
\end{tabular}


APÊNDICE 6 - Aquecimento da amostra - Processamento 2 - $80^{\circ} \mathrm{C}$ em água

\begin{tabular}{|c|c|c|c|c|c|}
\hline Tempo(min) & $\mathrm{T}^{\circ} \mathrm{C}$ Meio (água) & $\mathrm{T}^{\circ} \mathrm{C}$ (amostra) & Tref & $Z$ & TAXA LETAL \\
\hline 0 & 88,9 & 7,1 & 80 & 8,8 & 5,19887E-09 \\
\hline 2 & 89,9 & 8,5 & 80 & 8,8 & 7,49894E-09 \\
\hline 4 & 89,6 & 9,2 & 80 & 8,8 & 9,00628E-09 \\
\hline 6 & 90,5 & 10,5 & 80 & 8,8 & 1,26553E-08 \\
\hline 8 & 92,2 & 11 & 80 & 8,8 & 1,44242E-08 \\
\hline 10 & 92 & 12,7 & 80 & 8,8 & 2,25047E-08 \\
\hline 12 & 90,7 & 15 & 80 & 8,8 & 4,10806E-08 \\
\hline 14 & 90 & 17,9 & 80 & 8,8 & 8,77368E-08 \\
\hline 16 & 89,5 & 20,2 & 80 & 8,8 & 1,60157E-07 \\
\hline 18 & 90,1 & 22,3 & 80 & 8,8 & $2,77448 \mathrm{E}-07$ \\
\hline 20 & 91,1 & 24 & 80 & 8,8 & 4,32876E-07 \\
\hline 22 & 90,9 & 24,2 & 80 & 8,8 & 4,56132E-07 \\
\hline 24 & 90,8 & 26,2 & 80 & 8,8 & 7,69775E-07 \\
\hline 26 & 90,1 & 28,8 & 80 & 8,8 & 1,51991E-06 \\
\hline 28 & 89,8 & 31,4 & 80 & 8,8 & $3,00105 E-06$ \\
\hline 30 & 89,4 & 33,3 & 80 & 8,8 & 4,9338E-06 \\
\hline 32 & 88,7 & 36,4 & 80 & 8,8 & 1,11034E-05 \\
\hline 34 & 92,2 & 38,3 & 80 & 8,8 & 1,82542E-05 \\
\hline 36 & 92,9 & 40 & 80 & 8,8 & 2,84804E-05 \\
\hline 38 & 92,4 & 42,1 & 80 & 8,8 & 4,9338E-05 \\
\hline 40 & 91,6 & 43,6 & 80 & 8,8 & 7,30527E-05 \\
\hline 42 & 90,9 & 45,9 & 80 & 8,8 & 0,000133352 \\
\hline 44 & 90,1 & 47,6 & 80 & 8,8 & 0,000208057 \\
\hline 46 & 89,5 & 49,5 & 80 & 8,8 & 0,000342051 \\
\hline 48 & 88,8 & 51,1 & 80 & 8,8 & 0,000519887 \\
\hline 50 & 90,7 & 53,1 & 80 & 8,8 & 0,000877368 \\
\hline 52 & 90,8 & 54,4 & 80 & 8,8 & 0,001232847 \\
\hline 54 & 90,1 & 55,9 & 80 & 8,8 & 0,001825423 \\
\hline 56 & 89,5 & 57,5 & 80 & 8,8 & 0,002774481 \\
\hline 58 & 88,8 & 58,7 & 80 & 8,8 & 0,003797917 \\
\hline 60 & 90,8 & 60,1 & 80 & 8,8 & 0,005478181 \\
\hline 62 & 91,5 & 61,3 & 80 & 8,8 & 0,007498942 \\
\hline 64 & 91 & 62,5 & 80 & 8,8 & 0,010265111 \\
\hline 66 & 90 & 63,8 & 80 & 8,8 & 0,014424173 \\
\hline 68 & 89,5 & 65 & 80 & 8,8 & 0,019744882 \\
\hline 70 & 88,8 & 66 & 80 & 8,8 & 0,025650209 \\
\hline
\end{tabular}




\begin{tabular}{|c|c|c|c|c|c|}
\hline Tempo (min) & $\mathrm{T}^{\circ} \mathrm{C}$ Meio (água) & $\mathrm{T}^{\circ} \mathrm{C}$ (amostra) & Tref & Z & TAXA LETAL \\
\hline 72 & 90,8 & 67,6 & 80 & 8,8 & 0,038986037 \\
\hline 74 & 91,5 & 68,2 & 80 & 8,8 & 0,045613239 \\
\hline 76 & 91 & 69,2 & 80 & 8,8 & 0,05925531 \\
\hline 78 & 90 & 70,2 & 80 & 8,8 & 0,076977471 \\
\hline 80 & 90,4 & 70,9 & 80 & 8,8 & 0,092450463 \\
\hline 82 & 89,5 & 71,8 & 80 & 8,8 & 0,116998911 \\
\hline 84 & 88,8 & 72,5 & 80 & 8,8 & 0,140516483 \\
\hline 86 & 88,2 & 73,2 & 80 & 8,8 & 0,168761248 \\
\hline 88 & 90,1 & 73,9 & 80 & 8,8 & 0,2026834 \\
\hline 90 & 94,9 & 74,5 & 80 & 8,8 & 0,237137371 \\
\hline 92 & 94,5 & 75 & 80 & 8,8 & 0,270282658 \\
\hline 94 & 94,3 & 75,6 & 80 & 8,8 & 0,316227766 \\
\hline 96 & 93,5 & 76,2 & 80 & 8,8 & 0,369983041 \\
\hline 98 & 92,8 & 76,6 & 80 & 8,8 & 0,410805608 \\
\hline 100 & 92 & 77,4 & 80 & 8,8 & 0,506460354 \\
\hline 102 & 91 & 78 & 80 & 8,8 & 0,592553098 \\
\hline 104 & 90,3 & 78,3 & 80 & 8,8 & 0,640941189 \\
\hline 106 & 89,7 & 79,9 & 80 & 8,8 & 0,974173617 \\
\hline 108 & 89 & 80 & 80 & 8,8 & 1 \\
\hline 110 & 89,8 & 80,9 & 80 & 8,8 & 1,265530823 \\
\hline 112 & 89,5 & 81,3 & 80 & 8,8 & 1,405164835 \\
\hline 114 & 88,7 & 81,5 & 80 & 8,8 & 1,480657277 \\
\hline 116 & 23,5 & 81,5 & 80 & 8,8 & 1,480657277 \\
\hline 118 & 26,5 & 81,6 & 80 & 8,8 & 1,519911083 \\
\hline 120 & 25,8 & 81,6 & 80 & 8,8 & 1,519911083 \\
\hline 122 & 25,8 & 81,6 & 80 & 8,8 & 1,519911083 \\
\hline 124 & 25,8 & 81,6 & 80 & 8,8 & 1,519911083 \\
\hline 126 & 25,8 & 81,6 & 80 & 8,8 & 1,519911083 \\
\hline 128 & 25,8 & 81,7 & 80 & 8,8 & 1,560205549 \\
\hline 130 & 25,8 & 81,7 & 80 & 8,8 & 1,560205549 \\
\hline 132 & 21,6 & 81,7 & 80 & 8,8 & 1,560205549 \\
\hline 134 & 21,1 & 81,9 & 80 & 8,8 & 1,64402755 \\
\hline 136 & 20,4 & 81,7 & 80 & 8,8 & 1,560205549 \\
\hline 138 & 19,9 & 81,5 & 80 & 8,8 & 1,480657277 \\
\hline 140 & 19,6 & 80,7 & 80 & 8,8 & 1,201006767 \\
\hline 142 & 19,7 & 79 & 80 & 8,8 & 0,769774706 \\
\hline
\end{tabular}




\begin{tabular}{|c|c|c|c|c|c|}
\hline Tempo(min) & $\mathrm{T}^{\circ} \mathrm{C}$ Meio (água) & $\mathrm{T}^{\circ} \mathrm{C}$ (amostra) & Tref & $Z$ & TAXA LETAL \\
\hline 144 & 19,4 & 77,9 & 80 & 8,8 & 0,577249594 \\
\hline 146 & 19,4 & 76,6 & 80 & 8,8 & 0,410805608 \\
\hline 148 & 19,4 & 74,8 & 80 & 8,8 & 0,256502091 \\
\hline 150 & 19,4 & 73,3 & 80 & 8,8 & 0,173235288 \\
\hline 152 & 19,4 & 71,8 & 80 & 8,8 & 0,116998911 \\
\hline 154 & 19,4 & 69,8 & 80 & 8,8 & 0,069328067 \\
\hline 156 & 19,4 & 66,7 & 80 & 8,8 & 0,030806075 \\
\hline 158 & 19,4 & 65,5 & 80 & 8,8 & 0,022504674 \\
\hline 160 & 19,4 & 64,5 & 80 & 8,8 & 0,017323529 \\
\hline 162 & 19,4 & 62,5 & 80 & 8,8 & 0,010265111 \\
\hline 164 & 19,4 & 60,8 & 80 & 8,8 & 0,006579332 \\
\hline 166 & 19,4 & 59,3 & 80 & 8,8 & 0,004443521 \\
\hline 168 & 19,4 & 57,7 & 80 & 8,8 & 0,00292354 \\
\hline 170 & 19,4 & 55,5 & 80 & 8,8 & 0,001644028 \\
\hline 172 & 19,4 & 54,3 & 80 & 8,8 & 0,001201007 \\
\hline 174 & 19,4 & 53 & 80 & 8,8 & 0,000854709 \\
\hline 176 & 19,4 & 51,4 & 80 & 8,8 & 0,000562341 \\
\hline 178 & 19,4 & 50,1 & 80 & 8,8 & 0,000400196 \\
\hline 180 & 19,4 & 48,5 & 80 & 8,8 & 0,000263302 \\
\hline 182 & 19,4 & 47,6 & 80 & 8,8 & 0,000208057 \\
\hline 184 & 19,3 & 46,3 & 80 & 8,8 & 0,000148066 \\
\hline 186 & 19,4 & 45 & 80 & 8,8 & 0,000105372 \\
\hline 188 & 19,4 & 43,7 & 80 & 8,8 & 7,49894E-05 \\
\hline 190 & 19,3 & 42,7 & 80 & 8,8 & 5,7725E-05 \\
\hline 192 & 19,2 & 41,8 & 80 & 8,8 & 4,56132E-05 \\
\hline 194 & 19,2 & 40,5 & 80 & 8,8 & 3,24611E-05 \\
\hline 196 & 19,2 & 39,8 & 80 & 8,8 & 2,70283E-05 \\
\hline \multicolumn{5}{|c|}{ Somatório das taxas letais } & 32,62821648 \\
\hline
\end{tabular}


APÊNDICE 7 - Aquecimento da amostra - Processamento 1 - $80^{\circ} \mathrm{C}$ em vapor

\begin{tabular}{|c|c|c|c|c|c|}
\hline Tempo(min) & $\mathrm{T}^{\circ} \mathrm{C}$ Meio (estufa) & $\mathrm{T}^{\circ} \mathrm{C}$ (amostra) & Tref & $\mathrm{Z}$ & TAXA LETAL \\
\hline 0 & 32,7 & 4,8 & 80 & 8,8 & 2,85E-09 \\
\hline 2 & 42 & 5,3 & 80 & 8,8 & 3,25E-09 \\
\hline 4 & 58,8 & 5,3 & 80 & 8,8 & 3,25E-09 \\
\hline 6 & 82 & 5,7 & 80 & 8,8 & 3,6E-09 \\
\hline 8 & 91,6 & 6,6 & 80 & 8,8 & 4,56E-09 \\
\hline 10 & 91,1 & 7,9 & 80 & 8,8 & 6,41E-09 \\
\hline 12 & 91,2 & 10,1 & 80 & 8,8 & $1,14 \mathrm{E}-08$ \\
\hline 14 & 90,2 & 12,8 & 80 & 8,8 & 2,31E-08 \\
\hline 16 & 89,8 & 15,1 & 80 & 8,8 & $4,22 \mathrm{E}-08$ \\
\hline 18 & 89,5 & 18,5 & 80 & 8,8 & $1,03 E-07$ \\
\hline 20 & 91,1 & 21,8 & 80 & 8,8 & 2,43E-07 \\
\hline 22 & 91,2 & 23,7 & 80 & 8,8 & 4E-07 \\
\hline 24 & 90,2 & 26,3 & 80 & 8,8 & $7,9 \mathrm{E}-07$ \\
\hline 26 & 90,8 & 28 & 80 & 8,8 & 1,23E-06 \\
\hline 28 & 90,8 & 30,6 & 80 & 8,8 & 2,43E-06 \\
\hline 30 & 90,9 & 32,7 & 80 & 8,8 & $4,22 \mathrm{E}-06$ \\
\hline 32 & 90,3 & 35,1 & 80 & 8,8 & 7,9E-06 \\
\hline 34 & 91 & 37,3 & 80 & 8,8 & 1,41E-05 \\
\hline 36 & 90,1 & 39,5 & 80 & 8,8 & 2,5E-05 \\
\hline 38 & 90,1 & 41,7 & 80 & 8,8 & 4,44E-05 \\
\hline 40 & 89,9 & 44,3 & 80 & 8,8 & 8,77E-05 \\
\hline 42 & 89,7 & 47,2 & 80 & 8,8 & 0,000187 \\
\hline 44 & 89,8 & 48,2 & 80 & 8,8 & 0,000243 \\
\hline 46 & 90,5 & 50,3 & 80 & 8,8 & 0,000422 \\
\hline 48 & 90,2 & 52,2 & 80 & 8,8 & 0,000693 \\
\hline 50 & 89,8 & 54,5 & 80 & 8,8 & 0,001266 \\
\hline 52 & 89,8 & 56,5 & 80 & 8,8 & 0,002136 \\
\hline 54 & 90 & 58,1 & 80 & 8,8 & 0,003246 \\
\hline 56 & 90,2 & 59,8 & 80 & 8,8 & 0,005065 \\
\hline 58 & 90,2 & 61,1 & 80 & 8,8 & 0,007117 \\
\hline 60 & 90,8 & 62,5 & 80 & 8,8 & 0,010265 \\
\hline 62 & 90,2 & 63,9 & 80 & 8,8 & 0,014807 \\
\hline 64 & 90 & 65,2 & 80 & 8,8 & 0,020806 \\
\hline 66 & 90,2 & 67,2 & 80 & 8,8 & 0,035112 \\
\hline 68 & 90,2 & 68,4 & 80 & 8,8 & 0,048064 \\
\hline 70 & 89,8 & 69,4 & 80 & 8,8 & 0,062439 \\
\hline
\end{tabular}




\begin{tabular}{|c|c|c|c|c|c|}
\hline Tempo (min) & $\mathrm{T}^{\circ} \mathrm{C}$ Meio (estufa) & $\mathrm{T}^{\circ} \mathrm{C}$ (amostra) & Tref & Z & TAXA LETAL \\
\hline 72 & 90,1 & 70,2 & 80 & 8,8 & 0,076977 \\
\hline 74 & 90,2 & 71,3 & 80 & 8,8 & 0,102651 \\
\hline 76 & 89,1 & 72,3 & 80 & 8,8 & 0,133352 \\
\hline 78 & 89,4 & 73 & 80 & 8,8 & 0,160157 \\
\hline 80 & 89,8 & 74 & 80 & 8,8 & 0,208057 \\
\hline 82 & 89,9 & 74,8 & 80 & 8,8 & 0,256502 \\
\hline 84 & 90 & 75,4 & 80 & 8,8 & 0,300105 \\
\hline 86 & 89,8 & 76,1 & 80 & 8,8 & 0,360428 \\
\hline 88 & 89,8 & 76,7 & 80 & 8,8 & 0,421697 \\
\hline 90 & 89,9 & 77,4 & 80 & 8,8 & 0,50646 \\
\hline 92 & 89,8 & 78 & 80 & 8,8 & 0,592553 \\
\hline 94 & 89,6 & 78,4 & 80 & 8,8 & 0,657933 \\
\hline 96 & 90,1 & 78,9 & 80 & 8,8 & 0,749894 \\
\hline 98 & 90 & 79,5 & 80 & 8,8 & 0,877368 \\
\hline 100 & 90,1 & 80 & 80 & 8,8 & 1 \\
\hline 102 & 90,2 & 80,4 & 80 & 8,8 & 1,110336 \\
\hline 104 & 89,9 & 80,8 & 80 & 8,8 & 1,232847 \\
\hline 106 & 90,3 & 81,1 & 80 & 8,8 & 1,333521 \\
\hline 108 & 65,6 & 81,8 & 80 & 8,8 & 1,601568 \\
\hline 110 & 24,3 & 82,1 & 80 & 8,8 & 1,732353 \\
\hline 112 & 25,7 & 82,2 & 80 & 8,8 & 1,778279 \\
\hline 114 & 27,4 & 82,2 & 80 & 8,8 & 1,778279 \\
\hline 116 & 21,2 & 82 & 80 & 8,8 & 1,687612 \\
\hline 118 & 20,8 & 81,2 & 80 & 8,8 & 1,368875 \\
\hline 120 & 19,8 & 79,4 & 80 & 8,8 & 0,854709 \\
\hline 122 & 19,4 & 77,5 & 80 & 8,8 & 0,519887 \\
\hline 124 & 19,4 & 75,2 & 80 & 8,8 & 0,284804 \\
\hline 126 & 19,3 & 72,8 & 80 & 8,8 & 0,151991 \\
\hline 128 & 19,3 & 70,3 & 80 & 8,8 & 0,079018 \\
\hline 130 & 19,3 & 68 & 80 & 8,8 & 0,043288 \\
\hline 132 & 19,3 & 65,4 & 80 & 8,8 & 0,021923 \\
\hline 134 & 19,3 & 62,3 & 80 & 8,8 & 0,009742 \\
\hline 136 & 19,3 & 60,7 & 80 & 8,8 & 0,006409 \\
\hline 138 & 19,3 & 58 & 80 & 8,8 & 0,003162 \\
\hline 140 & 19,2 & 56,4 & 80 & 8,8 & 0,002081 \\
\hline 142 & 19,3 & 54,3 & 80 & 8,8 & 0,001201 \\
\hline 144 & 19,3 & 52,7 & 80 & 8,8 & 0,00079 \\
\hline 146 & 19,3 & 50,8 & 80 & 8,8 & 0,000481 \\
\hline
\end{tabular}




\begin{tabular}{cccccc}
\hline Tempo $(\mathrm{min})$ & $\mathrm{T}^{\circ} \mathrm{C}$ Meio (estufa) & $\mathrm{T}^{\circ} \mathrm{C}($ amostra) & Tref & $\mathrm{Z}$ & TAXA LETAL \\
\hline 148 & 19,3 & 49,2 & 80 & 8,8 & 0,000316 \\
150 & 19,3 & 47,4 & 80 & 8,8 & 0,000197 \\
152 & 19,3 & 45,9 & 80 & 8,8 & 0,000133 \\
154 & 19,3 & 44,5 & 80 & 8,8 & $9,25 \mathrm{E}-05$ \\
156 & 19,3 & 43,2 & 80 & 8,8 & $6,58 \mathrm{E}-05$ \\
158 & 19,3 & 42 & 80 & 8,8 & $4,81 \mathrm{E}-05$ \\
160 & 19,2 & 40,7 & 80 & 8,8 & $3,42 \mathrm{E}-05$ \\
162 & 19,3 & 39,6 & 80 & 8,8 & $2,57 \mathrm{E}-05$ \\
\multicolumn{2}{l}{ Somatório de taxas letais } & & & & 22,22026 \\
\hline
\end{tabular}


APÊNDICE 8 - Aquecimento da amostra - Processamento 2 - $80^{\circ} \mathrm{C}$ em vapor

\begin{tabular}{|c|c|c|c|c|c|}
\hline Tempo(min) & $\mathrm{T}^{\circ} \mathrm{C}$ Meio (estufa) & $\mathrm{T}^{\circ} \mathrm{C}($ amostra $)$ & Tref & $Z$ & TAXA LETAL \\
\hline 0 & 74,5 & 5,5 & 80 & 8,8 & 3,42E-09 \\
\hline 2 & 89,4 & 5,8 & 80 & 8,8 & 3,7E-09 \\
\hline 4 & 88,8 & 6,2 & 80 & 8,8 & 4,11E-09 \\
\hline 6 & 93,4 & 6,5 & 80 & 8,8 & 4,44E-09 \\
\hline 8 & 90,3 & 7 & 80 & 8,8 & 5,06E-09 \\
\hline 10 & 84,9 & 7,6 & 80 & 8,8 & 5,93E-09 \\
\hline 12 & 93,7 & 8,4 & 80 & 8,8 & 7,31E-09 \\
\hline 14 & 87,1 & 9,6 & 80 & 8,8 & $1 \mathrm{E}-08$ \\
\hline 16 & 81,7 & 11 & 80 & 8,8 & 1,44E-08 \\
\hline 18 & 77,1 & 12,9 & 80 & 8,8 & 2,37E-08 \\
\hline 20 & 70,8 & 14,4 & 80 & 8,8 & 3,51E-08 \\
\hline 22 & 68,8 & 16,2 & 80 & 8,8 & $5,62 \mathrm{E}-08$ \\
\hline 24 & 67,7 & 18,3 & 80 & 8,8 & 9,74E-08 \\
\hline 26 & 62,8 & 20,6 & 80 & 8,8 & $1,78 \mathrm{E}-07$ \\
\hline 28 & 74,3 & 22,5 & 80 & 8,8 & 2,92E-07 \\
\hline 30 & 88,3 & 24,7 & 80 & 8,8 & $5,2 \mathrm{E}-07$ \\
\hline 32 & 92 & 27 & 80 & 8,8 & $9,49 \mathrm{E}-07$ \\
\hline 34 & 91,1 & 29,2 & 80 & 8,8 & 1,69E-06 \\
\hline 36 & 90,6 & 30,8 & 80 & 8,8 & 2,57E-06 \\
\hline 38 & 91,6 & 32,5 & 80 & 8,8 & 4E-06 \\
\hline 40 & 92,8 & 34,7 & 80 & 8,8 & $7,12 \mathrm{E}-06$ \\
\hline 42 & 91,1 & 36,4 & 80 & 8,8 & 1,11E-05 \\
\hline 44 & 90,5 & 38,2 & 80 & 8,8 & 1,78E-05 \\
\hline 46 & 90 & 40,2 & 80 & 8,8 & $3 E-05$ \\
\hline 48 & 92 & 42 & 80 & 8,8 & 4,81E-05 \\
\hline 50 & 90,8 & 44 & 80 & 8,8 & 8,11E-05 \\
\hline 52 & 90,8 & 45,7 & 80 & 8,8 & 0,000127 \\
\hline 54 & 90,9 & 47,5 & 80 & 8,8 & 0,000203 \\
\hline 56 & 90,6 & 49,5 & 80 & 8,8 & 0,000342 \\
\hline 58 & 90,3 & 51,1 & 80 & 8,8 & 0,00052 \\
\hline 60 & 91,2 & 52,9 & 80 & 8,8 & 0,000833 \\
\hline 62 & 90,5 & 54,4 & 80 & 8,8 & 0,001233 \\
\hline 64 & 90,4 & 56 & 80 & 8,8 & 0,001874 \\
\hline 66 & 91,2 & 57,9 & 80 & 8,8 & 0,003081 \\
\hline 68 & 91,2 & 59 & 80 & 8,8 & 0,004108 \\
\hline 70 & 90,6 & 60,3 & 80 & 8,8 & 0,005772 \\
\hline
\end{tabular}




\begin{tabular}{|c|c|c|c|c|c|}
\hline Tempo (min) & $\mathrm{T}^{\circ} \mathrm{C}$ Meio (estufa) & $\mathrm{T}^{\circ} \mathrm{C}$ (amostra) & Tref & Z & TAXA LETAL \\
\hline 72 & 91,1 & 61,8 & 80 & 8,8 & 0,008547 \\
\hline 74 & 90,9 & 62,8 & 80 & 8,8 & 0,011103 \\
\hline 76 & 90,9 & 64,1 & 80 & 8,8 & 0,015602 \\
\hline 78 & 91,1 & 65,5 & 80 & 8,8 & 0,022505 \\
\hline 80 & 90,7 & 66,3 & 80 & 8,8 & 0,027745 \\
\hline 82 & 91,1 & 67,3 & 80 & 8,8 & 0,036043 \\
\hline 84 & 91,2 & 68,4 & 80 & 8,8 & 0,048064 \\
\hline 86 & 90,8 & 69,4 & 80 & 8,8 & 0,062439 \\
\hline 88 & 90,8 & 70,5 & 80 & 8,8 & 0,083263 \\
\hline 90 & 91,6 & 71,6 & 80 & 8,8 & 0,111034 \\
\hline 92 & 91,1 & 72,3 & 80 & 8,8 & 0,133352 \\
\hline 94 & 91,2 & 73,2 & 80 & 8,8 & 0,168761 \\
\hline 96 & 90,8 & 73,9 & 80 & 8,8 & 0,202683 \\
\hline 98 & 90,9 & 74,7 & 80 & 8,8 & 0,249878 \\
\hline 100 & 90,9 & 75,6 & 80 & 8,8 & 0,316228 \\
\hline 102 & 91,3 & 76,2 & 80 & 8,8 & 0,369983 \\
\hline 104 & 90,5 & 76,9 & 80 & 8,8 & 0,444352 \\
\hline 106 & 90,8 & 77,5 & 80 & 8,8 & 0,519887 \\
\hline 108 & 90,5 & 78,4 & 80 & 8,8 & 0,657933 \\
\hline 110 & 90,7 & 78,8 & 80 & 8,8 & 0,730527 \\
\hline 112 & 90,6 & 79,6 & 80 & 8,8 & 0,900628 \\
\hline 114 & 90,7 & 80,1 & 80 & 8,8 & 1,026511 \\
\hline 116 & 90,9 & 80,7 & 80 & 8,8 & 1,201007 \\
\hline 118 & 21,6 & 82,8 & 80 & 8,8 & 2,080568 \\
\hline 120 & 21,1 & 82,8 & 80 & 8,8 & 2,080568 \\
\hline 122 & 20,4 & 82,8 & 80 & 8,8 & 2,080568 \\
\hline 124 & 19,9 & 83,2 & 80 & 8,8 & 2,31013 \\
\hline 126 & 19,6 & 83,5 & 80 & 8,8 & 2,498776 \\
\hline 128 & 19,7 & 83,5 & 80 & 8,8 & 2,498776 \\
\hline 130 & 19,4 & 83,4 & 80 & 8,8 & 2,434241 \\
\hline 132 & 19,4 & 83 & 80 & 8,8 & 2,192346 \\
\hline 134 & 19,4 & 82,3 & 80 & 8,8 & 1,825423 \\
\hline 136 & 19,4 & 81,2 & 80 & 8,8 & 1,368875 \\
\hline 138 & 19,5 & 80,2 & 80 & 8,8 & 1,053725 \\
\hline 140 & 19,4 & 78,7 & 80 & 8,8 & 0,71166 \\
\hline 142 & 19,4 & 77,1 & 80 & 8,8 & 0,468225 \\
\hline
\end{tabular}




\begin{tabular}{cccccc}
\hline Tempo (min) & $\mathrm{T}^{\circ} \mathrm{C}$ Meio (estufa) & $\mathrm{T}^{\circ} \mathrm{C}($ amostra $)$ & Tref & $\mathrm{Z}$ & TAXA LETAL \\
\hline 144 & 19,4 & 75,4 & 80 & 8,8 & 0,300105 \\
146 & 19,4 & 73,7 & 80 & 8,8 & 0,192349 \\
148 & 19,4 & 71,8 & 80 & 8,8 & 0,116999 \\
150 & 19,3 & 69,9 & 80 & 8,8 & 0,071166 \\
152 & 19,4 & 68,2 & 80 & 8,8 & 0,045613 \\
154 & 19,4 & 66 & 80 & 8,8 & 0,02565 \\
156 & 19,4 & 64,4 & 80 & 8,8 & 0,016876 \\
158 & 19,4 & 63,5 & 80 & 8,8 & 0,013335 \\
160 & 19,4 & 61,3 & 80 & 8,8 & 0,007499 \\
162 & 19,4 & 59,9 & 80 & 8,8 & 0,005199 \\
164 & 19,4 & 58,3 & 80 & 8,8 & 0,003421 \\
166 & 19,4 & 56,6 & 80 & 8,8 & 0,002192 \\
168 & 19,4 & 55 & 80 & 8,8 & 0,001442 \\
170 & 19,3 & 53,4 & 80 & 8,8 & 0,000949 \\
172 & 19,3 & 51,6 & 80 & 8,8 & 0,000593 \\
174 & 19,3 & 50,2 & 80 & 8,8 & 0,000411 \\
176 & 19,3 & 48,9 & 80 & 8,8 & 0,000292 \\
178 & 19,3 & 47,5 & 80 & 8,8 & 0,000203 \\
180 & 19,4 & 46,1 & 80 & 8,8 & 0,000141 \\
182 & 19,4 & 44,9 & 80 & 8,8 & 0,000103 \\
184 & 19,3 & 43,6 & 80 & 8,8 & $7,31 \mathrm{E}-05$ \\
186 & 19,2 & 42,4 & 80 & 8,8 & $5,34 \mathrm{E}-05$ \\
188 & 19,2 & 41,2 & 80 & 8,8 & $3,9 \mathrm{E}-05$ \\
190 & 19,2 & 40,1 & 80 & 8,8 & $2,92 \mathrm{E}-05$ \\
Somatório de taxas letais & & & & 31,77498 \\
\hline & & & & &
\end{tabular}

